UNIVERSIDADE DE SÃO PAULO

INSTITUTO DE FÍSICA

INSTITUTO DE QUÍMICA

INSTITUTO DE BIOCIÊNCIAS

FACULDADE DE EDUCAÇÃO

DAIANE BEATRIZ SANTANA DOS SANTOS

\title{
Abordagens de tecnologia presentes nos livros didáticos de química
}

SÃO PAULO

2017 


\title{
Abordagens de tecnologia presentes nos livros didáticos de química
}

\author{
Versão Corrigida
}

Dissertação apresentada ao Instituto de Física, ao Instituto de Química, ao Instituto de Biociências e à Faculdade de Educação da Universidade de São Paulo como requisito parcial para a obtenção do título de Mestre em Ensino de Ciências.

Área de concentração: Ensino de Química

Orientadora: Profa. Dra. Carmen Fernandez

São Paulo 


\section{FICHA CATALOGRÁFICA \\ Preparada pelo Serviço de Biblioteca e Informação \\ do Instituto de Física da Universidade de São Paulo}

Santos, Daiane Beatriz Santana dos

Abordagens de tecnologia presentes nos livros didáticos de química.

São Paulo, 2017.

Dissertação (Mestrado) - Universidade de São Paulo.

Faculdade de Educação, Instituto de Física, Instituto de Química e Instituto de Biociências.

Orientador: Profa. Dra. Carmen Fernandez

Área de Concentração: Ensino de Química

Unitermos: 1. Química - Estudo e ensino; 2. Livros; 3. Ensino Médio; 4. Tecnologia.

$\mathrm{USP} / \mathrm{IF} / \mathrm{SBI}-043 / 2017$ 
Aos meus pais, Pedro e Nelci que sempre lutaram para que seus filhos pudessem ter as oportunidades que eles não tiveram, que trabalharam muito para que eu pudesse sonhar com uma vida melhor. Esse trabalho é o início de uma caminhada que só foi possível por vocês. 


\section{AGRADECIMENTOS}

Uma caminhada nunca é feita sozinha. Quero expressar aqui meu profundo agradecimento às pessoas que ajudaram a tornar o meu sonho uma realidade.

À minha orientadora Carmen Fernandez, um grande anjo em minha vida. Exemplo de profissional dedicada, agradeço por ter me ajudado a não desistir em meio à dificuldade. Agradeço pelas correções, sugestões, por ter me acolhido como membro do PEQuim e acreditado no meu potencial.

Ao professor Elio Carlos Ricardo, por todas as contribuições no início de meu projeto e no exame de qualificação. Fico muitas vezes admirada com tanto conhecimento.

À professora Leila Freire, pelas grandes contribuições na qualificação e também pelas ótimas aulas na graduação. Você é uma profissional maravilhosa, que admiro muito. Um dos grandes exemplos que pretendo carregar para minha vida profissional.

Ao grupo PEQuim, por toda a ajuda e apoio, agradeço muito todas as reuniões, discussões, contribuições e conversas informais que me auxiliaram muito a construir este trabalho.

Ao Programa de Pós-Graduação Interunidades em Ensino de Ciências e à CAPES pela oportunidade de cursar o mestrado e pela bolsa concedida.

Aos professores, colegas e funcionários do Programa Interunidades em Ensino de Ciências, por toda a ajuda nessa caminhada.

Aos meus amigos da graduação, que se tornaram meus irmãos, Fabi, Daiane, Thaiz, Caroline, Karine, Ivan, Vitor, Renan e Gefferson. Foram tantas risadas e apertos juntos, minha vida se tornou mais fácil e leve com vocês ao meu lado.

Aos amigos que fiz na estrada dessa vida, Cristiele, Valéria, Hualace, Rodrigo e Jean, sem dúvida vocês são as pessoas mais engraçadas que conheço. Tenho muita saudade de todos os momentos que vivemos juntos, sempre estarão em meu coração.

Às minhas amigas Lis e Elis, formamos um ótimo trio. Vocês, mesmo à distância, sempre estiveram dispostas a me ouvir, me apoiar e me animar. Não tenho palavras para descrever o amor que sinto por vocês.

Às minhas eternas PLYSAS. Fran, Elaine, Dani, Aline e Angela, ao lado de vocês eu cresci, amadureci e só me tornei o que sou hoje pelo convívio e amizade com vocês. Espero que nossa amizade dure eternamente.

À Sirlene, Israel, Aline e Lia, minha segunda família, que me viram crescer e compartilharam momentos comigo. Desconheço pessoas tão generosas e boas como vocês. Não cabe em meu coração toda a gratidão que tenho por vocês.

Ao Rômulo, por todos os momentos, pelo companheirismo, compreensão, por sua paciência sem limites, pelo incentivo constante, dedicação e amor. Você é um grande companheiro, é o meu melhor amigo, meu grande amor. 
Aos meus pais, Nelci e Pedro, meu trabalho é para vocês, é construído com o meu amor por vocês. Obrigada por todos os ensinamentos e por acreditarem em mim. Obrigada pela oportunidade de estudar, de ir atrás dos meus sonhos. Nem todas as palavras do mundo seriam suficientes para agradecer tudo que vocês fizeram e fazem por mim.

Aos meus irmãos, Altair, Ana e Adeli, por todo o carinho e dedicação, pelos puxões de orelha quando criança e pelos conselhos. Eu sei que em todos os momentos da minha vida vou poder contar com vocês. Nosso laço não é apenas o sangue, é o amor que construímos todos os dias.

Aos meus cunhados, Avarildo, Edson e Ana por todo o carinho. Obrigada pelos almoços de domingo, pelas discussões e o carinho.

Às flores da minha vida, Ana Lívia e Lavínia, as princesas mais lindas do mundo. A tia ama muito vocês.

Agradeço também a Deus pela minha vida, por ter condições para realizar o meu trabalho e pelas pessoas especiais que encontrei.

Eu amo vocês!!!

"Não é sobre ter todas as pessoas do mundo pra si, é sobre saber que em algum lugar alguém zela por ti..." (Ana Vilela) 


\section{RESUMO}

SANTOS, Daiane Beatriz Santana dos. Abordagens de tecnologia presentes nos livros didáticos de química. 2017. 158f. Dissertação (Mestrado em Ensino de Ciências) - Instituto de Química, Instituto de Física, Instituto de Biociências e Faculdade de Educação, Universidade de São Paulo, São Paulo, 2017.

A tecnologia está presente de forma crescente em vários campos da sociedade e na educação tem sido bastante abordada no movimento CTS. Este trabalho tem como objetivo principal a análise dos livros didáticos de química do Ensino Médio e a elucidação das principais abordagens sobre tecnologia presentes nesses textos. Os dados analisados compreenderam trabalhos de pesquisa nos principais periódicos brasileiros da área de ensino de ciências, documentos oficiais que orientam esse ensino, editais de seleção e guias de livros didáticos assim como as quatro coleções de livros didáticos de química aprovadas no Plano Nacional do Livro Didático de 2015. A análise realizada foi baseada na análise de conteúdo utilizando categorias provenientes da literatura e categorias que emergiram dos textos. A análise dos documentos oficiais, do guia e dos editais de seleção dos livros didáticos revela que a tecnologia é considerada um conteúdo obrigatório no ensino de química. Um levantamento feito nos principais periódicos brasileiros da área de ensino de ciências revelou que a tecnologia é pouco pesquisada nesse contexto. Os trabalhos apontam que a principal concepção de tecnologia é a de ciência aplicada. Por outro lado, os documentos oficiais apontam para a importância de um ensino CTS, dos alunos compreenderem o processo histórico de desenvolvimento da tecnologia e compreenderem o funcionamento de artefatos tecnológicos. A análise dos livros didáticos revela que $79 \%$ dos exemplos encontrados apontam que tecnologia é ciência aplicada e em $8 \%$ aparecem como sinônimo de técnica. Em $12 \%$ dos trechos analisados a tecnologia influencia o desenvolvimento da ciência, entretanto na maioria dos casos é apresentada a ideia de modelo linear de desenvolvimento científico e tecnológico. Os livros didáticos também apresentam alguns exemplos de cultura tecnológica intrínseca e extrínseca. Na cultura tecnológica extrínseca dividiram-se os exemplos em otimismo e pessimismo tecnológico, acessibilidade da tecnologia, neutralidade da tecnologia e tecnologia muda a forma de ver o mundo. O número de exemplos em que a tecnologia foi vista de forma otimista é superior aos exemplos pessimistas. A tecnologia foi apresentada mais como fonte de exemplificação do que como fonte de conteúdo e também foi utilizada no livro como uma forma de justificar a aprendizagem da ciência. Assim, aparecem contradições entre as concepções de tecnologia veiculadas nos livros e as estabelecidas nos documentos oficiais. Tais contradições dificultam o trabalho dos professores em sala de aula e podem estar na raiz das visões equivocadas encontradas do termo. Dessa forma, trabalhar efetivamente a tecnologia em sala de aula requer uma mudança na postura tradicional, que tende a reduzir a tecnologia à mera ciência aplicada. Tal mudança passa necessariamente pela atualização de algumas ideias veiculadas pelos livros didáticos.

Palavras-chave: Ensino de Tecnologia, Ensino de Química, Livro Didático de Química. 


\begin{abstract}
SANTOS, Daiane Beatriz Santana dos. Technology approaches in chemistry textbooks. 2017. 158f. Dissertation (Master in Science Education) Physics Institute, Chemistry Institute, Biosciences Institute and Faculty of Education, University of São Paulo, 2017.

Technology is present increasingly in various fields of society and in education has been greatly addressed in the CTS movement. The aim of this work is the analysis of high school chemistry textbooks and the elucidation of the main approaches on technology present in these texts. The data analyzed included research work in the main Brazilian journals in the area of science education, official documents that guide this teaching, selection process and textbook guides as well as the four collections of chemistry textbooks approved in the National Textbook Plan of 2015. The analysis was based on the content analysis using categories from the literature and categories that emerged from the texts. The analysis of the official documents, the guide and the textbook selection processes reveals that technology is considered an obligatory content in teaching chemistry. A survey carried out in the main Brazilian journals in the field of science education revealed that technology is little researched in this context. The works show that the main concept of technology is applied science. On the other hand, official documents point to the importance of CTS teaching, students understanding of the historical process of technology development and understanding of the operation of technological artifacts. The analysis of the textbooks reveals that $79 \%$ of the examples found point out that technology is applied science and in 8\% they appear as synonymous with technique. In $12 \%$ of the extracts analyzed technology influences the development of science. However, in most cases the idea of a linear model of scientific and technological development is presented. The textbooks also present some examples of intrinsic and extrinsic technological culture. In the extrinsic technological culture the examples were divided into optimism and technological pessimism, technology accessibility, technology neutrality and technology modifies the way we see the world. The number of examples in which the technology was viewed optimistically is superior to pessimistic examples. Technology was presented more as a source of exemplification than as a source of subject matter and was also used in the book as a way of justifying the learning of science. Thus, contradictions appear between the conceptions of technology conveyed in the books and those established in the official documents. Such contradictions make the work of teachers difficult in the classroom and may be at the root of the mistaken views of the term. Thus, effectively working the technology in the classroom requires a change in the traditional posture, which tends to reduce technology to mere applied science. Such change necessarily involves the updating of some ideas conveyed by textbooks.
\end{abstract}

Keywords: Technology Teaching, Chemistry Teaching, Chemistry Textbooks. 


\section{LISTA DE TABELAS}

Tabela 1: Classificação dos artigos encontrados nas revistas.

Tabela 2. Trechos retirados da apresentação dos livros didáticos da coleção 2 que abordam tecnologia. .90

Tabela 3. Trechos que abordam a tecnologia na apresentação das coleções 1 e 4 91

Tabela 4. Tecnologia como ciência aplicada 97

Tabela 5. Artefatos tecnológicos que utilizam conceitos químicos. 100

Tabela 6. Artefatos tecnológicos e seus materiais químicos 102

Tabela 7. Explicação do funcionamento de um artefato tecnológico 106

Tabela 8. Exemplos de modelo linear de desenvolvimento científico e tecnológico 111

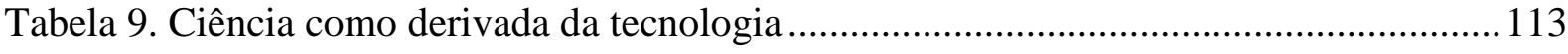

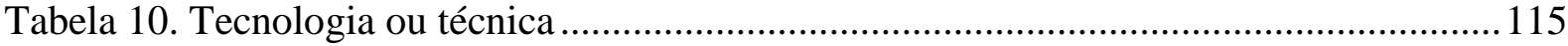

Tabela 11 Exemplos de importância de patentes................................................................... 118

Tabela 12 Exemplos de questões de mercado .................................................................... 118

Tabela 13 Exemplos de questões de mercado ....................................................................... 120

Tabela 14 Exemplos de desafios enfrentados na tecnologia .................................................. 121

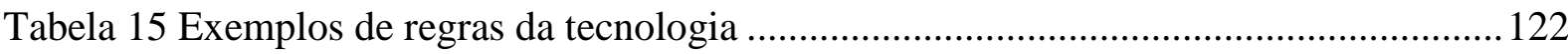

Tabela 16 Exemplos de pessimismo tecnológico envolvendo poluição................................. 124

Tabela 17 Exemplos relacionados ao consumismo ............................................................. 125

Tabela 18 Exemplos da tecnologia para controle ............................................................... 127

Tabela 19 Exemplos da tecnologia para reverter estragos da tecnologia .............................. 130

Tabela 20 Processo de reciclagem como uma tecnologia ..................................................... 130

Tabela 21 Tecnologia como capaz de fazer coisas que o ser humano seria incapaz de fazer 131

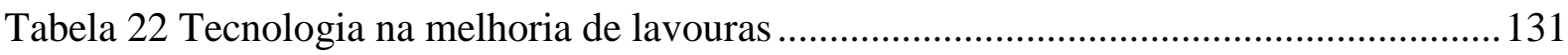

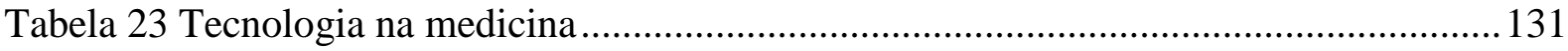

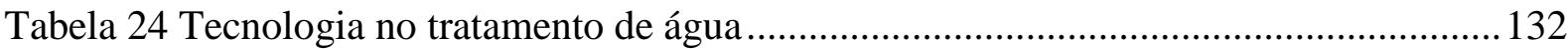

Tabela 25 Tecnologia para a produção de energia ................................................................ 132

Tabela 26 Tecnologia na melhoria de produtos................................................................... 133

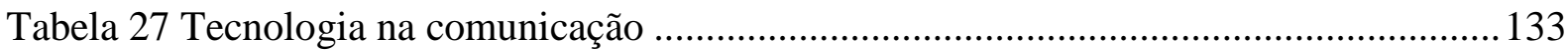

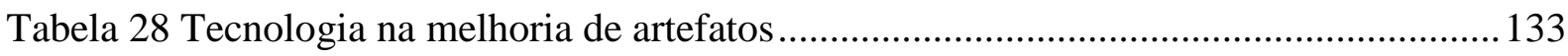

Tabela 29 Tecnologia na melhoria da qualidade de vida .................................................. 134

Tabela 30 Tecnologia na questão de energia ..................................................................... 134 
Tabela 31 Acessível a poucos

Tabela 32 Acessível a muitos 135

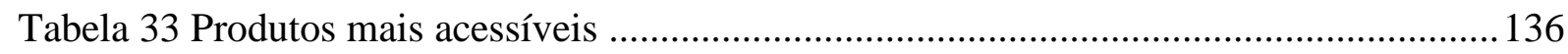

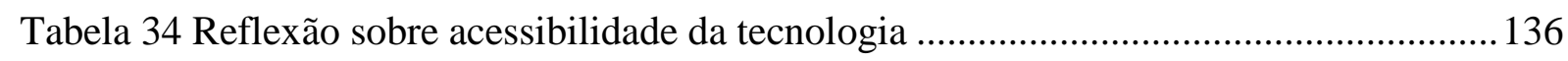

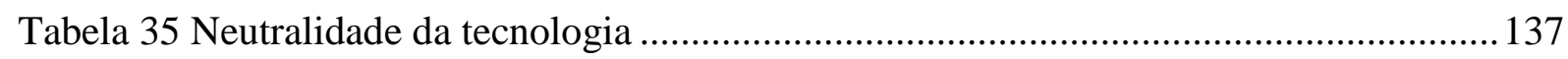

Tabela 36 Tecnologia muda a forma de ver o mundo .......................................................... 140

Tabela 37 Quantidade de exemplos de cada coleção em relação ao significado da tecnologia 142

Tabela 38 Quantidade de exemplos de cada coleção em relação à cultura tecnológica 143 


\section{LISTA DE QUADROS}

Quadro 1: Diferenciação entre ciência e tecnologia. Fonte: Utges (1996)............................. 40

Quadro 2: Diferenciação entre ciência e tecnologia Fonte: Gilbert (1995) .............................. 40

Quadro 3: Diferenciação entre ciência e tecnologia Fonte: Gilbert (1995)) ........................... 40

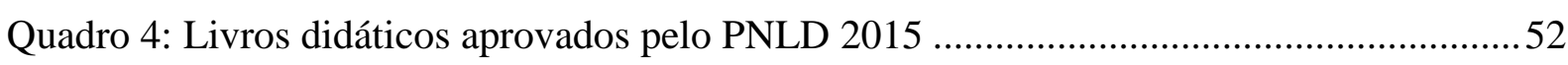

Quadro 5: Categorias utilizadas nas análises dos livros didáticos.........................................57

Quadro 6: Lista de periódicos analisados ..............................................................................59

Quadro 7: Número de trabalhos encontrados por revista no período de 2000 a 2015 .............59

\section{LISTA DE FIGURAS}

Figura 1 Exemplo (53) de explicação do funcionamento de um artefato tecnológico (C4, L1, p. 189) 108

Figura 2: Exemplo (54) de explicação do funcionamento de um artefato tecnológico (C4, L2 p.208) 108

Figura 3: Exemplo (55) de explicação do funcionamento de um artefato tecnológico 109

\section{LISTA DE GRÁFICOS}

Gráfico 1: Quantidade de exemplos do livro em que é discutido o significado da tecnologia 94 Gráfico 2: Tecnologia é boa ou má? 140

Gráfico 3: Comparação entre a quantidade de exemplos que discutem sobre tecnologia de cada coleção. 


\section{SUMÁRIO}

1 INTRODUÇÃ $O$.....................................................................................................................13

1.1 Apresentação .................................................................................................................. 13

1.2 Objetivos ...................................................................................................................... 18

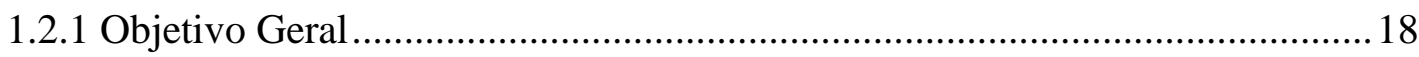

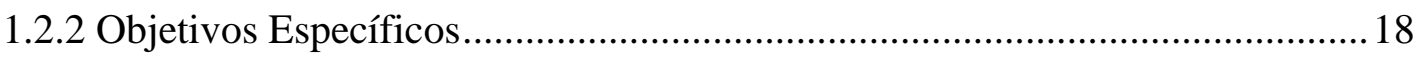

2 FUNDAMENTAÇÃO TEÓRICA......................................................................................... 19

2.1 Pesquisas sobre abordagem CTS.............................................................................. 19

2.2 Alfabetização Científica e Tecnológica .................................................................23

2.3 Educação Tecnológica................................................................................................25

2.4 A Questão da tecnologia ...........................................................................................31

2.5 Livro Didático.............................................................................................................44

3 ASPECTOS METODOLÓGICOS DA PESQUISA ………................................................50

4 RESULTADOS E DISCUSSÕES ........................................................................58

4.1 A literatura e o Ensino de tecnologia ........................................................................58

4.2 A tecnologia nos documentos oficiais de Ensino de Ciências .............................80

4.3 A tecnologia no GLD e editais do PNLD.................................................................85

4.4 A tecnologia nos Livros Didáticos...........................................................................8 88

4.4.1 O SIGNIFICADO DA TECNOLOGIA ……………………………….......94

4.4.1.1 Tecnologia como ciência aplicada ..................................................................94

4.4.1.1.1 Artefatos tecnológicos que utilizam conceitos, teorias e leis da química...99

4.4.1.1.2 Elementos ou substâncias químicas presentes em artefatos tecnológicos 102

4.4.1.1.3 Explicação do funcionamento de um artefato tecnológico ......................... 105

4.4.1.1.4 Modelo linear de desenvolvimento científico e tecnológico ......................110

4.4.1.3 Tecnologia ou Técnica ............................................................................. 114

4.3.1.4 Discussão do significado da tecnologia .....................................................116 
4.4.2.1 Cultura Tecnológica Intrínseca .................................................................... 117

4.4.2.2 Cultura Tecnológica Extrínseca ....................................................................... 123

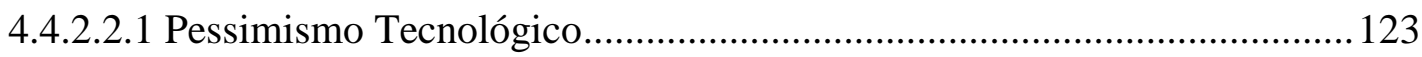

4.4.2.2.2 Otimismo Tecnológico ............................................................................. 129

4.4.2.2.3 Acessibilidade da tecnologia................................................................... 134

4.4.2.2.4 Neutralidade da Tecnologia ...................................................................... 137

4.4.2.2.5 Tecnologia muda a forma de ver o mundo ……………………….......... 140

4.4.3 Discussão geral da tecnologia em cada uma das coleções de livros didáticos 141

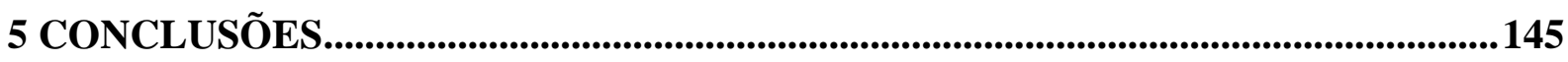

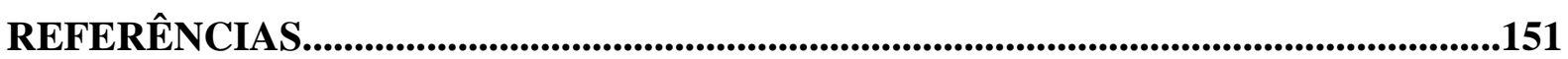




\section{INTRODUÇÃO}

\subsection{Apresentação}

A aprendizagem da Química é de fundamental importância para a formação da cidadania numa sociedade democrática. Vive-se em uma sociedade em que ciência e tecnologia estão presentes na vida diária, mas mesmo assim a educação escolar tem pouco a ver com a vida do aluno. Considerando-se que o objetivo geral da educação básica é preparar para o exercício da cidadania e, dada a presença da ciência e tecnologia na sociedade, é fundamental que esses aspectos sejam discutidos na escola. $\mathrm{O}$ ensino de ciências e tecnologia deve desenvolver no aluno a capacidade de tomar decisões em nossa sociedade. Segundo a Constituição Brasileira de 1988:

\footnotetext{
A educação, direito de todos e dever do Estado e da família, será promovida e incentivada com a colaboração da sociedade, visando ao pleno desenvolvimento da pessoa, seu preparo para o exercício da cidadania e sua qualificação para o trabalho (BRASIL, 1988, art. 205).
}

Dessa forma, uma educação para a cidadania é direito de todos, garantido na Constituição Brasileira. O ensino médio não pode se limitar ao preparo para o vestibular, os conteúdos de ciência e tecnologia presentes devem fornecer ao aluno conhecimento para exercer essa cidadania. Segundo Santos e Schnetzler (1997), os avanços tecnológicos promovem impacto no desenvolvimento dos países, modificam a vida das pessoas, causam efeitos ambientais e impactam as decisões dos indivíduos na sociedade. Assim, surgiu um movimento de grande destaque, que busca estabelecer relações entre ciência, tecnologia e sociedade (CTS).

A LDB, Lei de Diretrizes e Bases da Educação Nacional, lei máxima que rege a educação nacional, aponta no artigo 35 que uma das finalidades do ensino médio é a “compreensão dos fundamentos científico-tecnológicos dos processos produtivos, relacionando a teoria com a prática, no ensino de cada disciplina" (BRASIL, 1996, p. 34). Também, artigo 36, parágrafo $1^{\circ}$ da LDB afirma que o educando, até o final do ensino médio, deve demonstrar "domínio dos princípios científicos e tecnológicos que presidem a produção moderna" (BRASIL, 1996, p. 34). Sendo assim, o ensino de ciências e tecnologia é um direito 
de todos os cidadãos, garantido na legislação. Entretanto, muitos alunos saem da escola sem saber discutir e argumentar sobre esses temas.

O ensino sobre ciência e tecnologia nas escolas pode auxiliar o aluno a compreender melhor os fenômenos que acontecem ao seu redor e a exercer melhor a sua cidadania. Além disso, não basta apenas inserir temas de ciência e tecnologia na sala de aula, é necessário que esses temas sejam discutidos de maneira que permitam uma mudança de pensamento e de comportamento nos alunos. A escola procura fornecer ao aluno uma nova forma de ver o mundo e torná-lo capaz de ser um sujeito ativo na sociedade, em busca de uma sociedade mais humana e igualitária. Segundo Firme e Amaral (2008), o desenvolvimento científico e tecnológico tem provocado mudanças na sociedade, tanto gerando desenvolvimento quanto uma série de problemas, assim, o processo educativo deve incluir questões relativas à ciência e tecnologia.

$\mathrm{Na}$ sociedade atual, a tecnologia vem influenciando o contexto político, social, econômico e também dentro da escola, causando profundas transformações sociais que não podem ser ignoradas pelo professor. A escola mudou, os alunos mudaram e a sociedade de uma forma geral mudou com o desenvolvimento tecnológico. Vivemos um novo momento social, onde temos um novo aluno imerso em um mundo tecnológico. Segundo Ferreira, GilPérez e Vilches (2006), a repercussão da tecnologia na vida cotidiana, como aspectos econômicos, sociais, culturais, históricos, filosóficos e relacionados à ciência, já seria uma justificativa para a introdução da tecnologia no ensino. Gilbert (1995) destaca que essa influência da tecnologia na sociedade fez surgir na década de 80 e 90 do século passado a ideia da incorporação da tecnologia no currículo.

Para responder aos anseios da sociedade em relação ao ensino de ciências e tecnologia, é fundamental discutir sobre como esse ensino deve ocorrer, buscando compreender a educação voltada para a cidadania. A atividade científica e tecnológica está carregada de mitos e crenças em relação ao conhecimento. Uma pesquisa de Bispo et al. (2013) mostra que os professores não compreendem a relação entre ciência, tecnologia e sociedade, aquilo que o autor chamou de "crenças ingênuas" sobre CTS. Para evitar isto, torna-se necessário maior discussão a respeito do significado desses termos nas pesquisas, bem como de suas relações.

Firme e Amaral (2008) também investigaram as concepções dos professores de Química sobre CTS e suas inter-relações. Para os autores é fundamental estudar sobre as 
concepções de CTS dos professores, pois elas influenciam na prática docente. As concepções apresentadas pelos professores revelam que eles não conseguem definir ciência e tecnologia de forma satisfatória e acreditam que a tecnologia é desenvolvida por meio da ciência, ou seja, ela seria apenas uma aplicação dos conhecimentos científicos. A pesquisa também mostrou que os professores subvalorizam a tecnologia em relação à ciência. Segundo Firme e Amaral (2008), parece haver uma incompreensão por parte dos professores sobre o significado da ciência e da tecnologia e uma desvalorização da importância da tecnologia na sociedade acreditando que ela é derivada da ciência.

Kist e Ferraz (2010) também investigaram a visão de tecnologia de professores de biologia e revelou-se uma visão de tecnologia como sendo ciência aplicada, salvacionista onde tudo que a tecnologia produz é para o bem-estar da sociedade, reducionista e de determinismo tecnológico, acreditando que tudo que é produzido em laboratório leva a algo útil e benéfico ao ser humano. Ricardo, Custódio e Rezende (2007) e Fourez (2003) também mostram resultados semelhantes em pesquisas em relação à compreensão do significado da tecnologia por professores.

Tais pesquisas revelam que, apesar da tecnologia estar totalmente presente na vida do ser humano, de ser um fator determinante em questões políticas, econômicas e sociais e do consenso existente entre pesquisadores da importância do seu ensino, sendo inclusive obrigatório na escola segundo alguns documentos oficiais, os professores não compreendem totalmente o seu significado. Esses dados levam a questionar se os alunos estariam vivenciando um ensino de tecnologia satisfatório, uma vez que estes adquirem e operam diariamente produtos tecnológicos, mas não necessariamente compreendem o seu funcionamento e as questões sociais envolvidas na utilização da tecnologia. Outra questão em aberto é se os alunos estariam sendo conscientizados dos riscos e implicações da utilização desses artefatos na sociedade. Todo esse cenário requer que a tecnologia esteja presente em discussões na sala de aula, para que conhecimentos úteis e fundamentais para a vida em sociedade não sejam excluídos do contexto escolar. Dada a importância da tecnologia para a sociedade, essa discussão deve ser trazida para o espaço escolar, ainda mais considerando o tempo que os alunos, futuros cidadãos, passam nesse espaço.

O ensino de ciências conta com várias questões e dúvidas, entretanto, o ensino da tecnologia é ainda muito menos claro. Utges et al. (2001) mostram que já existem muitos 
trabalhos na América Latina abordando o ensino de ciências, discutindo possiblidades, dificuldades e dúvidas em relação à educação científica e à formação de professores de ciências. Porém, quando o assunto é ensino de tecnologia, são escassos os trabalhos que abordam o tema. Os autores destacam a extrema importância de mais pesquisas abordarem o ensino de tecnologia, pois vários países o estão incorporando no currículo escolar, seja por meio do enfoque CTS, como uma disciplina isolada, seja dentro de outras disciplinas da área científica. Todavia, o tema é ainda bastante complexo, e não há consenso de como deve ser abordado em sala de aula. Apesar do trabalho de Utges et al. (2001) ser relativamente antigo, no decorrer do trabalho mostrou-se que ainda hoje há poucos trabalhos referentes ao tema.

Pinheiro, Silveira e Bazzo (2007) destacam que todos precisam ter acesso a conhecimentos de tecnologia, não apenas para saber utilizar e entender o funcionamento de artefatos tecnológicos, mas para poder participar ativamente e opinar sobre o uso desses produtos, entender que a tecnologia não é neutra, mas está ligada a aspectos econômicos, ambientais, políticos e sociais. Angotti, Bastos e Mion (2001) destacam que nós utilizamos artefatos tecnológicos diariamente, mas não compreendemos o seu funcionamento e as implicações sociais associadas ao seu uso, sendo importante discutir sobre tecnologia nas escolas, não apenas discutindo sua definição e o que ela significa, mas discutindo como a tecnologia afeta nossas vidas.

Apesar do ensino de tecnologia ser de grande importância social para a formação da cidadania, ainda são necessárias diversas discussões a respeito do tema, visando a esclarecer como ele pode ser transposto para o ensino em sala de aula, tanto em nível fundamental, quanto médio ou superior. Isso porque a sociedade tem propagado uma visão deformada de tecnologia, sendo vista como apenas ciência aplicada e com menor status que a ciência pura, ela também tem sido excluída da educação escolar e quando ensinada faz parte apenas de currículos de educação técnica (MAIZTEGUI et al. 2002; CACHAPUZ et al. 2005). Dessa forma, vemos que o ensino de tecnologia pode estar sendo bastante problemático.

Neste trabalho, a discussão irá se restringir ao ensino de tecnologia em nível médio, buscando analisar livros didáticos utilizados nesse nível. Uma vez que parece haver uma incompreensão dos professores sobre o significado da tecnologia e que ela não vem sendo abordada de maneira clara no ensino, e que se sabe que os livros didáticos exercem um papel 
formador de professores e alunos, a proposta de analisar livros didáticos é no sentido de verificar se os mesmos apresentam abordagens que possam auxiliar a ambos.

O livro didático possui grande importância para o ensino, pois o professor o utiliza para a preparação das aulas e o aluno o utiliza como fonte de consulta. Conhecimentos veiculados pelos livros didáticos podem interferir diretamente no ensino e na aprendizagem dos alunos em sala de aula. Dessa forma, torna-se relevante observar o que o livro didático aborda sobre a questão da tecnologia, buscando compreender melhor como esse assunto vem sendo tratado.

Será discutido também o espaço da tecnologia no ensino de ciências e na sociedade, apresentando discussões filosóficas sobre o que é tecnologia e suas relações com o ensino. Pretende-se, com tais discussões, circunscrever o problema central de como a tecnologia vem sendo abordada nos livros didáticos, para que, com isto, seja possível responder à seguinte questão de pesquisa: "Quais são as principais abordagens sobre tecnologia presentes nos livros didáticos de Química, utilizados atualmente no ensino médio no Brasil? ”

Também pretende-se responder a outras questões que envolvem o ensino de tecnologia: O que alguns autores compreendem como tecnologia? Qual a importância de a tecnologia ser abordada no ensino médio? Quais são as principais dificuldades para que uma educação tecnológica seja implementada?

Vale ressaltar que, quando nos referirmos ao ensino de tecnologia ou educação tecnológica, não estamos nos referindo ao ensino de ciências com a utilização de artefatos tecnológicos (por exemplo, o ensino de química utilizando um computador) que geralmente é conhecido como a utilização de TIC's na educação, mas sim ao ensino de tecnologia, no qual a própria tecnologia seja um objeto de ensino. Introduzir educação tecnológica no ensino de ciências não é o mesmo que usar a tecnologia para ensinar, a ideia não é pensar apenas em ensinar com tecnologia, mas sim ensinar a tecnologia e para o mundo tecnológico. Segundo Ricardo, Custódio e Rezende (2007), muitas vezes, a tecnologia é entendida apenas como a utilização de artefatos tecnológicos no ensino, como computadores, vídeos e outros. Neste caso a tecnologia é utilizada como um recurso para o ensino de conteúdos científicos e não como uma fonte de discussão sobre a própria tecnologia. 


\subsection{Objetivos}

\subsubsection{Objetivo Geral}

- Analisar as abordagens sobre tecnologia presentes nos livros didáticos de química aprovados pelo PNLD 2015 e distribuídos nas escolas de ensino médio brasileiras.

\subsubsection{Objetivos Específicos}

- Apresentar compreensões sobre tecnologia a partir da leitura de diversos autores.

- Revisar as concepções de tecnologia e educação tecnológica presentes na literatura.

- Discutir como é abordada a tecnologia nos documentos oficiais da área de ensino de Ciências e editais do PNLD 2015.

- Identificar as abordagens de tecnologia presentes nos livros didáticos de química do ensino médio aprovados pelo PNLD 2015. 


\section{FUNDAMENTAÇÃO TEÓRICA}

\subsection{Pesquisas sobre abordagem CTS}

Dada a importância da abordagem de questões relativas à ciência e à tecnologia, um movimento surgiu na década de 70 do século passado e ganhou destaque em vários setores da sociedade, sendo denominado pela sigla CTS - Ciência, Tecnologia e Sociedade - e mais recentemente CTSA, com maior ênfase na dimensão ambiental. O movimento teve origem na filosofia e sociologia da ciência. Anteriormente ao movimento, a visão que se compartilhava de ciência era bastante deformada, sendo vista como neutra e isolada. A ciência era vista amparada no positivismo lógico, onde o método científico era o elemento mais importante para o progresso da ciência e ela era considerada independente de fatores externos, como influências sociais. A tecnologia, por sua vez, era vista como a aplicação de conhecimentos científicos e de forma completamente neutra. O movimento CTS surge neste contexto para exigir maior reflexão sobre questões relativas à ciência e à tecnologia (ROEHRIG; CAMARGO, 2013). Entretanto, apesar da origem do movimento, algumas dessas questões ainda são consideradas problemáticas. O movimento CTS acabou não dando conta de responder a todas as questões. A questão da tecnologia acabou sendo negligenciada, como apontada por Maiztegui et al. (2002) que o "T maiúsculo" da questão "CTS" tem sido visto no máximo como um "t minúsculo".

A ciência e a tecnologia já foram vistas como sinônimos de progresso, porém, com o passar dos anos percebeu-se que elas não trazem apenas benefícios e seus benefícios não são para todos. O uso abusivo de aparatos tecnológicos tem mostrado que a população necessita refletir mais sobre ciência e tecnologia. Dessa forma, o movimento CTS se intensificou e influenciou também a escola (ANGOTTI; AUTH, 2001). O sentimento de que o desenvolvimento científico e tecnológico não traz apenas benefícios à humanidade foi se espalhando por uma parte da sociedade, surgindo a necessidade de discutir esses aspectos. A guerra do Vietnã, a guerra fria, a divulgação pela mídia de catástrofes ambientais, as armas químicas e biológicas, a publicação de obras como A Estrutura das Revoluções Científicas de Thomas Kuhn e Primavera Silenciosa de Rachel Carson são algumas razões para uma nova 
forma de ver as relações CTS e os marcos para o início do movimento (AULER; BAZZO, 2001).

O movimento CTS seguiu em três direções: campo de pesquisa, envolvendo a discussão acadêmica para uma visão socialmente contextualizada da atividade científica; campo das políticas públicas buscando a regulação social da ciência e da tecnologia; campo da educação, envolvendo a introdução de questões CTS no ensino (LINSINGEN, 2007).

Pinheiro, Silveira e Bazzo (2007) destacam que o movimento influenciou os currículos escolares de vários países, principalmente o de ciências. O movimento acabou afetando o ensino de ciências, pois a escola é um dos locais em que se difundem diversas ideias equivocadas sobre ciência. Segundo Aikenhead (2005, p. 114), o movimento surgiu no ensino a partir da necessidade de confrontar alguns assuntos, tais como: "a finalidade das escolas; políticas curriculares; a natureza do currículo de ciências; ensino e avaliação; o papel dos professores; a natureza da aprendizagem; a diversidade dos alunos, e o que significa ciência”. Para o autor, o movimento pode esclarecer diversas questões sobre como ensinar e porque ensinar ciências.

Currículos com ênfase em CTS tem por objetivo de aprendizagem a formação para a cidadania, incluindo a introdução de questões ambientais, políticas, sociais, econômicas e culturais, relacionadas à ciência e à tecnologia. Um dos objetivos de um currículo CTS é facilitar o entendimento dos alunos em relação à compreensão dos fenômenos que os cercam, possibilitando uma aproximação da ciência escolar e do conhecimento tecnológico com a sociedade.

Em alguns países como os Estados Unidos, até a década de 70 do século passado se priorizava um ensino de ciências na escola para a formação de pequenos cientistas. $\mathrm{O}$ aluno recebia conteúdos de ciências que pudessem prepará-lo para o ensino superior. Esse ensino foi característico do período da guerra fria, devido a necessidade de se formar cientistas. $\mathrm{O}$ cotidiano dos alunos não era valorizado e alunos sem interesse por ingressar na carreira científica não recebiam outra formação que pudesse ajudá-los no dia-dia. O surgimento do movimento CTS está relacionado com a insatisfação de uma parcela da comunidade acadêmica com a concepção de ciência e de tecnologia da época e as consequências na sociedade. Considerando o contexto educacional do ensino de ciências descrito, esse 
movimento também foi incorporado na área educacional e posteriormente se espalhou para boa parte dos países.

Com o surgimento das discussões CTS no início da década de 70 do século passado em âmbito internacional, nos Estados Unidos e em países europeus, novas ideias sobre o ensino de ciências passam a ser discutidas. $\mathrm{O}$ ensino de ciências passa a ter como objetivo a formação do aluno para a sociedade. No Brasil, a discussão sobre estudos CTS teve início na década de 80, porém apenas a partir de 2000 que a produção acadêmica sobre o tema começa a se consolidar. Auler e Bazzo (2001) destacam várias dificuldades para a implementação do movimento CTS no contex to brasileiro, entre elas o nosso passado colonial, a industrialização tardia do país, o modelo agrário-exportador que ainda é predominante, a democracia recente e frágil, pois na história do nosso país predominaram modelos de governo ditatoriais e totalitários, a falta de participação do povo nas decisões políticas e a ausência de um projeto de desenvolvimento científico e tecnológico do país.

Atualmente, vários documentos oficiais e pesquisadores sugerem a inserção de discussões CTS em sala de aula e muitas escolas estão trazendo essas discussões para a realidade em sala de aula. O tema CTS já é consolidado nas pesquisas do Brasil, pois há muitos artigos de pesquisadores brasileiros sobre o assunto. Apesar disso, poucas dessas mudanças são vistas na realidade de sala de aula (ROEHRIG; CAMARGO, 2013). Isso pode estar ligado a problemas na formação de professores e visões ingênuas dos mesmos em relação a esse assunto.

Em outros países, como os Estados Unidos, além das discussões CTS estarem presentes nas salas de aula da educação básica, elas também estão presentes nos cursos superiores. Isso porque se acredita que estudos CTS são de fundamental importância para a formação de profissionais qualificados. Em cursos de engenharia, por exemplo, temas CTS seriam de grande importância, pois além da formação técnica, é necessário que os engenheiros compreendam as influências sociais da ciência e da tecnologia.

Ao analisar periódicos nacionais e atas de congressos pode-se constatar que no Brasil ocorreu um aumento significativo nas pesquisas nos últimos anos, como nos mostra Abreu, Fernandes e Martins (2013) e Chrispino et al. (2013). No trabalho de Abreu, Fernandes e Martins (2013) foi feito um levantamento e análise dos trabalhos publicados sobre CTS nos principais periódicos nacionais, internacionais e nos principais congressos da área de ensino 
de ciências no período de 1980 a 2008. A pesquisa indica que até 2008 o número de artigos sobre CTS ainda era pequeno nos periódicos nacionais em relação à produção total do campo de pesquisa em ensino de ciências, apenas $0,8 \%$ da produção nacional da época abordava o tema CTS. Nos periódicos internacionais, $0,9 \%$ da produção abordava o tema CTS. Isso mostra que a nossa produção sobre trabalhos CTS está alinhada com os periódicos internacionais.

Também é possível verificar, por meio dos dados dos trabalhos acima que, no campo internacional, as pesquisas CTS têm suas primeiras publicações em periódicos nos anos de 1980 e o volume maior de trabalhos CTS ocorreu nos anos de 1990. Nos periódicos nacionais, as publicações se iniciam nos anos 2000 e o maior número de trabalhos ocorre em 2008. Os autores puderam concluir que apesar do crescimento de trabalhos sobre CTS, esse número ainda é bastante pequeno quando comparado com o total de publicações e outras áreas de pesquisa.

Isso indica que na época em que este trabalho foi publicado, a área CTS ainda estava em expansão, mas já possuía diversos autores e trabalhos brasileiros com destaque. Abreu, Fernandes e Martins (2013) destacam Décio Auler, Walter Antonio Bazzo, Wildson Santos, Eduardo Mortimer e Demétrio Delizoicov como os pesquisadores brasileiros de maior destaque na área e Glen Aikenhead, José Acevedo Diaz e Antônio Cachapuz como os estrangeiros mais citados nas publicações CTS. Os autores também perceberam que os trabalhos na área CTS são mais frequentes nos eventos acadêmicos da área que em publicações em periódicos. Isso pode vir a mostrar uma certa fragilidade teórica da área, poris acaba sendo mais fácil realizar trabalhos para congressos do que pesquisas em periódicos.

Araújo et al. (2009) pesquisaram os trabalhos CTS em eventos da área de ensino de ciências, como o ENPEC, ENEQ, SNEF, EPEB e ENEBIO no período de 2003 a 2006. 3 \% de todos os trabalhos publicados nesses periódicos nesse período abordam o movimento CTS, sendo que a química é a área de ensino com menos trabalhos publicados (Física 33\%, Ciências 23\%, Biologia 21\% e Química 19\%). Outro trabalho mais recente sobre o assunto pesquisou as publicações sobre CTS de 2009 a 2013 (FREITAS; GHEDIN, 2015). O trabalho mostra um significativo aumento nas pesquisas na área se comparada com anos anteriores a 2009. Esses trabalhos mostram que os artigos abordando o tema CTS estão em expansão e tem se discutido bastante sobre a área. 
No âmbito internacional, ocorreu um crescimento no número de pesquisas CTS em um determinado período, como nos mostra Cachapuz et al. (2008). Os autores fizeram um levantamento dos trabalhos publicados em três das principais revistas de circulação internacional (Science Education, Journal of Research in Science Teaching and International Journal of Science Education) no período de 1993 a 2002. Nessa década, o número de trabalhos que abordam o tema CTS triplicou no segundo quinquênio em relação ao primeiro quinquênio (CACHAPUZ, 2008).

\subsection{Alfabetização Científica e Tecnológica}

Outro termo bastante discutido atualmente na área de ensino de ciências é "alfabetização científica e tecnológica". O termo possui múltiplas definições e existem diversos trabalhos que enfocam o assunto. Nos trabalhos, a alfabetização científica é vista como a finalidade do ensino de ciências, sendo entendida por Chassot (2000, p.34) como "o conjunto de conhecimentos que facilitariam aos homens e mulheres fazer uma leitura do mundo onde vivem". O autor também destaca que "seria desejável que os alfabetizados cientificamente não apenas tivessem facilitada a leitura do mundo em que vivem, mas entendessem as necessidades de transformá-lo, e transformá-lo para melhor" (CHASSOT, 2000, p.34).

A alfabetização científica está profundamente ligada ao desenvolvimento da cidadania; em proporcionar ao aluno melhor compreensão da sociedade em que está inserido. Chassot (2003) considera que a alfabetização científica está ligada ao domínio de conhecimentos científicos e tecnológicos e esses conhecimentos são necessários para o cidadão conviver em sociedade e compreender o seu cotidiano. Fourez traz que a finalidade da alfabetização científica e tecnológica seria: “a autonomia do indivíduo (componente pessoal), a comunicação com os demais (componente cultural, social e teórico), e certo manejo do ambiente (componente econômico)" (FOUREZ, 1997, p. 16).

Acevedo (1996) destaca que uma boa forma de promover uma alfabetização científica e tecnológica nas escolas é a introdução das relações CTS nas aulas de Ciências. Acevedo et al. (2002) também afirmam que um dos objetivos dos programas de educação CTS é aumentar a alfabetização científica e tecnológica dos cidadãos. Dessa forma, o ensino 
CTS e a promoção de uma alfabetização científica e tecnológica nas escolas estão interligados, sendo um, consequência do outro.

Sasseron e Carvalho (2011) trazem outras diferentes nomenclaturas para este termo: Letramento Científico e Enculturação Científica. As autoras destacam que, independentemente das nomenclaturas, elas objetivam a educação dos alunos para a vida social; visando sua atuação crítica, responsável e cidadã.

Para Sasseron e Carvalho (2011) a alfabetização científica é o objetivo central do ensino de ciências, devido à necessidade de formar alunos ativos e atuantes para nossa sociedade, que hoje é cercada de artefatos tecnológicos. Novamente é nítida a ideia de que o desenvolvimento tecnológico e o uso de artefatos tecnológicos são usados como uma justificativa para aprender ciência, neste caso são usados para defender uma alfabetização científica e tecnológica na escola.

Apesar de haver alguns trabalhos que abordam o tema da alfabetização científica e tecnológica, percebe-se que muitas vezes não há uma clareza em como deve ser realizada a “alfabetização tecnológica", ou acredita-se que apenas uma "alfabetização científica" já seja suficiente e a "alfabetização tecnológica" seria uma consequência. Segundo Veraszto et al.:

Se a intenção é promover uma educação tecnológica mais crítica e construtiva, que preza pela formação participativa do cidadão, o ponto de partida é entender todas as facetas da tecnologia para, a partir de então, buscar também compreender como nossos estudantes entendem, se relacionam e o que esperam da mesma (VERASZTO et al., 2013, p.763).

Portanto, compreender as múltiplas definições e possíveis abordagens da tecnologia é de fundamental importância para construir uma verdadeira alfabetização tecnológica. Maiztegui et al. (2002) mostra que vem se falando muito da importância de uma alfabetização científica como uma necessidade urgente para a formação das pessoas, mas há também uma necessidade urgente de uma alfabetização tecnológica. Nas pesquisas fala-se sobre alfabetização científica e tecnológica ou sobre educação CTS, mas a questão da tecnologia tem ficado de lado, surgindo a necessidade de incluir a questão da tecnologia de forma específica e explícita como parte da educação geral. Os autores alertam para o caso de não se ter dado nenhuma atenção ao papel da tecnologia na alfabetização científica e tecnológica. 


\subsection{Educação Tecnológica}

Utges et al. (1996) acreditam que a educação tecnológica deve buscar uma compreensão crítica do mundo artificial, reconhecer os tipos de problemas que envolvem a tecnologia, as formas de abordar esses problemas, compreender como se gera e como evolui o mundo artificial, compreender e conhecer os artefatos tecnológicos, refletir sobre a sua utilização e buscar soluções para as problemáticas que envolvem a tecnologia. Ou seja, deve abordar a tecnologia como uma forma de transformar a realidade.

Gilbert (1995) nos traz alguns argumentos que defendem uma educação tecnológica. O primeiro argumento trazido pelo autor é o econômico, já que a tecnologia é peça fundamental para todas as atividades econômicas da sociedade, envolvendo muito dinheiro. Este argumento está relacionado com a preparação dos jovens para o mundo do trabalho, ou seja, o jovem que recebe uma educação tecnológica poderia estar mais bem preparado para a vida profissional em indústrias. Os trabalhos da linha CTS geralmente são contra esse argumento, por acreditarem que os alunos devem receber uma educação voltada para o desenvolvimento de habilidades básicas e conhecimentos para a vida em sociedade e não para o mundo do trabalho em indústrias.

O segundo argumento proposto por Gilbert (1995) para a educação tecnológica é o que o autor chama de argumento social. Ele sugere que o aluno deve ter conhecimento sobre tecnologia para poder tomar decisões pessoais, econômicas e sociais conscientes em nossa sociedade, o conhecimento servirá para tomar ações com mais clareza. O aluno também precisa ter conhecimento sobre tecnologia para ser possível compreender as consequências da tecnologia em nossa sociedade e para controlar seu uso no futuro.

O terceiro argumento apresentado pelo autor é o educativo. O primeiro ponto é que a tecnologia é uma das maiores realizações da humanidade, então todos os alunos devem ter contato com ela. O segundo ponto é que a tecnologia está presente em todos os lugares da nossa vida diária, então devemos ter conhecimento sobre ela. E o terceiro ponto, que engloba os argumentos anteriores, é que a educação tecnológica pode ser uma forma valiosa para se conseguir fins educativos.

Silva (2003) também destaca a importância de se trabalhar a tecnologia nas escolas e disse que a introdução dessa temática é um grande desafio para os professores. A autora 
destaca a importância de se repensar a formação de professores e de se investir em materiais didáticos específicos para facilitar o trabalho com essa temática. Acredita-se também que esse tema não deve ser inserido em apenas uma disciplina, mas deve ser trabalhado de forma interdisciplinar. Outro ponto importante é que o ensino de tecnologia não deve ser reduzido a um ensino profissionalizante ou descontextualizado, mas devem-se considerar os aspectos sociais, culturais e ter como objetivo a formação para a cidadania. Também é necessário levar em conta a pluralidade de definições do termo tecnologia e sua relação com a ciência.

Acevedo et al. (2003) também apresentam três razões que defendem o ensino de tecnologia. O primeiro motivo é o didático, onde a tecnologia pode ser utilizada para promover uma aprendizagem mais significativa, ajudar a compreender a vida cotidiana, contextualizar a ciência e aumentar o interesse dos alunos. O segundo motivo é o epistemológico, onde a tecnologia pode auxiliar a melhorar a compreensão da natureza da ciência. O terceiro é o social onde o ensino de tecnologia pode capacitar os cidadãos para viver em uma sociedade democrática, participando das decisões com conhecimento para opinar em questões tecnocientíficas.

Apesar da compreensão de que o ensino de ciências é tão importante como o ensino de tecnologia, percebe-se uma priorização da ciência e que ainda não é claro como deve ocorrer o ensino de tecnologia. Gilbert (1995) nos mostra que não há um consenso na literatura a respeito da definição de tecnologia e que esse consenso é ainda menor a respeito da educação tecnológica. O autor oferece alguns exemplos de como a tecnologia é abordada nas aulas de ciências:

Faz-se apenas uma referência mínima a exemplos de produtos tecnológicos durante as aulas.

Ensinam-se os conceitos científicos e faz-se uma ilustração de como podem ser usados na tecnologia.

Ensina-se e discute-se ciência, analisando o funcionamento de um produto tecnológico.

Os processos e produtos da tecnologia e da ciência se misturam e se confundem durante o ensino.

Não é ensinada a relação entre ciência, tecnologia e sociedade, diferenciando os aspectos das três. (GILBERT, 1995, p. 19)

Ao analisar esses exemplos de como a tecnologia vem sendo abordada nas aulas de ciências, pode-se perceber que na maioria dos casos a tecnologia é deixada em caráter secundário, onde se ensina apenas ciência e a tecnologia é usada como forma de exemplificação. Apesar da citação ser proveniente de um trabalho antigo, podemos fazer um 
paralelo com nosso ensino atual, onde acredita-se que a tecnologia ainda é vista como algo secundário.

Gilbert (1995) nos coloca ainda que uma forma de melhorar a educação tecnológica é modificar a formação de professores, pois os professores não estão preparados para trabalhar sobre tecnologia. Neste ponto, a pesquisa de Ricardo, Custódio e Rezende (2007) mostra concordância revelando que não há uma compreensão dos professores sobre o que é tecnologia e existe uma confusão entre a ciência aplicada e a tecnologia. Fourez (2003) também aborda que os professores não possuem formação para compreender a educação tecnológica, segundo o autor, "os estudos não estão muito preocupados em introduzi-los nem à prática tecnológica, nem à maneira como ciências e tecnologias se favorecem, nem às tentativas interdisciplinares" (FOUREZ, 2003, p.111). Fourez (2003) também comenta que os professores de ciências confundem tecnologia com a aplicação da ciência e que os professores pensam que se os alunos aprenderem ciência, a tecnologia é aprendida automaticamente. Outros trabalhos que mostram resultados semelhantes, isto é, que os professores não compreendem a tecnologia, já foram expostos anteriormente (FIRME; AMARAL, 2008; KIST; FERRAZ, 2010). Esses autores mostram que o problema central pode estar relacionado com a formação de professores de ciências, que não dá a atenção devida à tecnologia.

Acevedo et al. (2003) também pesquisou as crenças dos professores sobre tecnologia e suas relações com a ciência e mostrou que os professores de todos os níveis escolares, primário, secundário e universitário, possuem visões limitadas de tecnologia. As visões limitadas destacadas pelos autores se referem à visão de tecnologia como ciência aplicada, sempre subordinada à ciência ou dirigida por esta. Essas visões de tecnologia, na visão dos autores, mostram que os professores não possuem formação que lhes permita discutir adequadamente sobre tecnologia em sala de aula.

Em relação à formação de professores, Silva (2003) aplicou um questionário para licenciandos em Química com o objetivo de investigar a visão de tecnologia desses futuros professores. As respostas obtidas puderam ser classificadas em tradicional, utilitária, estratégica e objetos físicos. A visão tradicional de tecnologia foi compartilhada pela maioria dos licenciandos, onde se acredita que a tecnologia seja a ciência aplicada, ou seja, a tecnologia utiliza diretamente todos os conhecimentos advindos da ciência e assim vai se desenvolvendo. Esse resultado concorda com as demais pesquisas que mostram que essa 
concepção é comum em professores já formados. Outra visão de tecnologia compartilhada por uma expressiva quantidade de participantes foi da tecnologia como utilitarista. Neste caso, a tecnologia é vista como uma forma de resolver problemas, sendo associada ao progresso. A tecnologia também foi associada com objetos físicos, como produtos de informática. Na visão estratégica, a tecnologia é vista como uma forma de proporcionar melhores condições de vida para a população, auxiliando na melhoria da qualidade de vida e no desenvolvimento social. Sobre a relação da tecnologia com a ciência, $90 \%$ dos participantes da pesquisa acreditam que a tecnologia seja subordinada à ciência, reforçando ainda mais a ideia comumente aceita de que a tecnologia seja ciência aplicada. A autora justifica as ideias dos licenciandos em relação à tecnologia devido ao fato de que durante a trajetória formativa desses estudantes eles não tiveram acesso a uma educação reflexiva em relação à tecnologia (SILVA, 2003).

Se para os professores e licenciandos há uma confusão ao refletir sobre a tecnologia, para os alunos de nível médio isso é ainda mais confuso. Barros Filho et al. (2009) buscaram compreender o que os estudantes de ensino médio pensam e como definem tecnologia. A maioria dos alunos apenas associou a tecnologia com o uso de produtos como celular, computador, televisão, entre outros artefatos tecnológicos. Para os alunos, a tecnologia é sinônimo de artefatos tecnológicos e se resume a isso.

Os mesmos autores mostraram também que os alunos associaram a tecnologia como algo positivo, aquilo que o autor chamou de "otimismo tecnológico". Para os alunos, a tecnologia sempre melhora a vida do homem, enaltecendo seus benefícios e ignorando possíveis problemas relacionados ao uso de artefatos tecnológicos. Segundo os autores, essa concepção de "otimismo tecnológico" não é exclusiva de alunos, mas professores também compartilham dessa posição. Assim, surge a necessidade de estender as discussões sobre concepções de tecnologia ao ambiente escolar. Barros Filho et al. (2009) defendem que é necessário inserir discussões sobre tecnologia na escola, criando uma consciência crítica nos alunos e dando subsídios para compreenderem as implicações da tecnologia no nosso futuro. Isso é importante para que os alunos sejam capazes de tomar decisões na nossa sociedade.

Veraszto et al. (2013) investigaram a concepção de tecnologia de alunos de graduação de diferentes regiões do estado de São Paulo, buscando entender como esses graduandos pensam a relação entre tecnologia e sociedade. Os autores verificaram três concepções básicas dos graduandos sobre tecnologia. A maior parte dos graduandos apresenta a concepção de 
tecnologia como sendo intelectualista e sinônimo de ciência, instrumentalista e neutra. Ou seja, os graduandos confundem a tecnologia com a ciência, não tendo condições de distinguilas ou ainda apontam a tecnologia como derivada da ciência, ou seja, a tecnologia é a aplicação de algum modelo ou teoria da ciência. A noção de tecnologia como instrumentalista reflete a ideia da tecnologia como um produto ou artefato. Os autores destacam sobre essa concepção de tecnologia como sendo:

um ponto de vista que gera grandes confusões por acreditar que a produção
tecnológica consiste apenas nos equipamentos gerados a partir da mesma. Isto pode
fazer com que se acredite que basta saber ligar o equipamento, conhecer as siglas
que os fabricantes criam, e utilizá-lo, para ser expert em tecnologia. (VERASZTO et
al., 2013, p. 771)

Essa visão de tecnologia como um artefato foi compartilhada por vários sujeitos da pesquisa de Veraszto et al. (2013). A ideia de a tecnologia ser neutra reflete a falta de compreensão dos graduandos quanto à influência de fatores sociais, políticos e econômicos no desenvolvimento tecnológico. A tecnologia não é neutra, ela está correlacionada com aspectos da nossa sociedade. As pesquisas acima mencionadas mostram que não há muita clareza na definição de tecnologia, tanto para professores quanto para graduandos e alunos de ensino médio.

Cassab (2008) e Auler e Delizoicov (2001) abordam três mitos relacionados ao conhecimento tecnológico que são difundidos pela escola, que poderiam ser considerados uma visão reducionista da tecnologia: a crença na superioridade do modelo de decisões tecnocráticas, a perspectiva salvacionista da ciência e tecnologia e o determinismo tecnológico. Por meio do mito de superioridade do modelo de decisões tecnocráticas é difundida a ideia de que o conhecimento tecnológico é verdadeiro, seguro, objetivo e a única solução possível para os problemas da humanidade. Nesse caso, a ciência e a tecnologia são vistas como verdade absoluta, para a sociedade moderna elas podem ser comparadas a um deus para as igrejas. O conhecimento tecnológico também é restrito aos "experts", os únicos responsáveis por tomarem decisões, sendo a população excluída dessas decisões. Recai apenas aos especialistas em ciência e tecnologia todas as decisões sobre esses assuntos que deveriam ser problemas de todos os cidadãos.

O mito da perspectiva salvacionista se refere à ideia de que a solução para os problemas da população está no desenvolvimento tecnológico, toda tecnologia ou descoberta 
científica leva ao progresso e resolve os problemas da humanidade, tornando a vida mais fácil. Porém, nem sempre a ciência e a tecnologia afetam de maneira positiva a sociedade. $\mathrm{O}$ mito do determinismo tecnológico se refere à ideia de que a tecnologia determina a mudança social, definindo os limites do que a sociedade pode fazer e que ela é autônoma das influências sociais. Cassab (2008) atribui ao professor a tarefa de discutir esses mitos em sala de aula. Uma perspectiva ampliada buscaria problematizar e derrubar esses mitos.

Rinaldi e Guerra (2011) discutem que a população utiliza artefatos tecnológicos sem os conhecer, sem refletir sobre as vantagens e riscos da utilização da tecnologia e a falta de discussões sobre o assunto leva a população a acreditar em mitos sobre o conhecimento tecnológico, como o mito de que a tecnologia sempre melhora a qualidade de vida da população. Uma das formas de reverter esse cenário é a introdução de discussões sobre o ensino de tecnologia.

Nesse contexto, surge a necessidade de discutir e investigar o ensino de tecnologia nos currículos escolares. Vários países têm inserido o ensino de tecnologia nos currículos, inclusive o Brasil. Utges et al. (1996) comentam que a tecnologia não possui um espaço definido dentro das escolas, sendo trabalhada de diferentes formas de um país para outro e dentro do mesmo país e em muitos casos nem chega a ser trabalhada. Para o autor, existem várias formas de a tecnologia ser abordada, tanto como um conteúdo separado, uma disciplina separada ou dentro de outros conteúdos. Os casos em que a tecnologia é trabalhada dentro de outras disciplinas e conteúdos é mais comum e o autor defende que, dessa forma, a disciplina pode acabar se tornando até mais atrativa e interessante ao aluno, pois poderiam ser feitas relações CTS.

Fourez (2003) fala sobre a questão da Bélgica e explica que apesar da tecnologia estar sugerida nos objetivos e nos currículos de ensino de ciências, nesse país os alunos têm uma formação que é voltada apenas para a ciência e não para a tecnologia. Segundo o autor, os alunos "não recebem nenhuma formação para tecnologias. Apenas lhes é dito que sua formação científica servirá para compreender aquelas." (FOUREZ, 2003, p. 111) Fourez argumenta que os alunos da atualidade vivem em uma "tecno-natureza" e, portanto, apenas o ensino de ciências da natureza não é suficiente para compreender o mundo, mas seria necessário um ensino de tecnologia. Fourez (2003) também nos coloca que um dos motivos para a tecnologia não ser abordada em sala de aula, como está sugerida nos currículos, é que a 
formação dos professores não os permite discutir sobre tecnologia. Os professores recebem uma formação que lhes permite ser técnicos em ciências e possuem uma introdução à didática de sua disciplina, mas seus estudos não os introduzem a discussões a respeito da tecnologia.

Assim, os professores apresentam a tecnologia como uma aplicação da ciência, pois é mais fácil ver a tecnologia dessa forma. Nessa perspectiva, uma vez ensinada a ciência, a tecnologia é aprendida automaticamente. Utges (2001) aborda que a tecnologia foi inserida no currículo escolar da Argentina desde 1993, por meio de uma reforma na educação do país, tendo um papel relevante na Educação Básica e é proposta para todos os ciclos escolares. Os livros didáticos, a organização do currículo e especialistas da área sugerem que a tecnologia deve ser abordada e mostram visões distintas de como ela poderia ser discutida, porém não existem professores especificamente formados para trabalhar com tecnologia.

Ferreira, Gil-Pérez e Vilches (2006) falam que na Espanha, apesar da presença da tecnologia no cotidiano, ela tem sido esquecida, tanto na educação básica quanto em cursos científicos, sendo restrita apenas a cursos técnicos de educação profissional. Isso acontece porque a tecnologia não possui a mesma estima da ciência perante a sociedade, sendo vista como subordinada às ciências. A visão compartilhada pela população é de que a ciência estaria em um patamar mais elevado e a tecnologia seria apenas a aplicação dos seus conhecimentos. Entretanto, com o movimento CTS começou-se a discutir um pouco mais sobre a tecnologia no ensino. A legislação prevê que a tecnologia seja abordada como uma área independente no ensino secundário espanhol, porém ainda é necessária muita atenção em como deve ocorrer o ensino de tecnologia. No trabalho de Ferreira, Gil-Pérez e Vilches (2006) é feita a análise da imagem da tecnologia apontada pelos livros didáticos espanhóis utilizados no ensino secundário e a visão predominante nesse material ainda é de ciência aplicada.

\subsection{A Questão da tecnologia}

A tecnologia está presente no cotidiano do ser humano. Os artefatos tecnológicos se espalharam por todo canto. $\mathrm{Na}$ sociedade atual, fechar os olhos para a tecnologia é algo impossível, pois ela faz parte da vida do ser humano em vários contextos e situações. Hoje, a tecnologia se tornou um fator determinante na vida da população e seu desenvolvimento é 
usado como medida de qualidade de vida e desenvolvimento da sociedade. Ela é considerada um dos principais fatores de progresso e desenvolvimento e a chave do desenvolvimento social e econômico de uma região (SILVEIRA; BAZZO, 2009).

$\mathrm{Na}$ formação de um cidadão crítico e atuante na sociedade, é necessário discutir sobre a tecnologia. No cotidiano há muitos discursos em que a palavra tecnologia está presente seja pela mídia, na escola ou em conversas informais. Na escola, ouve-se quase diariamente o termo tecnologia, em várias disciplinas. Porém, percebe-se uma grande dificuldade para definir o termo de forma que haja um consenso. Segundo Utges (1996) existem muitas definições para tecnologia, desde algumas muito amplas até outras extremamente restritas. Alguns filósofos vêm trazendo discussões sobre o tema tecnologia, que serão apresentadas aqui. Pretende-se discutir a existência de diferentes compreensões para o termo tecnologia, pensar na sua natureza complexa e de múltiplos significados e, como isso, pode vir a interferir no ensino de ciências.

No cotidiano a tecnologia está geralmente associada com artefatos tecnológicos, como computadores e celulares, também é vista como uma aplicação de conhecimentos científicos e é muito confundida com a palavra técnica. O uso diário da palavra tecnologia leva a acreditar que todos sabem o seu significado. Porém, essas definições do cotidiano podem ser limitadas e assim a definição trazida por alguns filósofos da tecnologia será discutida.

Cupani (2013) em sua obra "Filosofia da tecnologia: um convite" traz uma reflexão a respeito da tecnologia, incentivando novas pesquisas sobre o tema que ainda tem discussões escassas no contexto da pesquisa. $\mathrm{O}$ autor destaca que a tecnologia é muito importante para o mundo contemporâneo e enfatiza a complexidade que envolve o estudo da tecnologia, pois há bastante divergência entre os autores sobre a sua definição e seus preceitos. Também é destacado como a filosofia da tecnologia ainda é bastante recente e é um tema bastante heterogêneo. Nessa obra, Cupani apresenta diversos autores que trazem discussões sobre a filosofia da tecnologia e definições de tecnologia. Como definição para a tecnologia, Cupani (2013, p. 17/18) apresenta algumas concepções defendidas por vários filósofos e ressalta que a definição de tecnologia não é unânime, o autor cita como exemplos:

[...] "fabricação e uso de artefatos" (MITCHAN, 1994); "uma forma de conhecimento humano" endereçada a "criar uma realidade conforme nossos propósitos" (SKOLIMOWSKI, 1983); "conhecimento que funciona, know-how" (JARVIE, 1983); “implementações práticas da inteligência” (FERRÉ, 1995); "a humanidade trabalhando [at work]” (PITT, 2000); colocação da Natureza à 
disposição do homem como recurso (HEIDEGGER, 1997); “o campo de conhecimento relativo ao projeto de artefatos e à planificação de sua realização, operação, ajustamento, manutenção e monitoramento, à luz do conhecimento científico" (BUNGE, 1985), o modo de vida próprio da modernidade (BORGMANN, 1984); "a totalidade dos métodos a que se chega racionalmente e que têm eficiência absoluta (para um dado estágio do desenvolvimento) em todo campo de atividade humana" (ELLUL, 1964,); "a estrutura material da Modernidade" (FEENBERG, 2002).

Além dessas definições sobre tecnologia, Cupani (2013) dá ênfase em quatro dimensões da tecnologia, defendidas por Mitcham (1994) que são: i) como objeto: no caso seriam os artefatos tecnológicos; ii) como conhecimento: uma classe específica de conhecimento, o conhecimento tecnológico; iii) como atividade humana: atividades para produzir e utilizar artefatos tecnológicos e iv) como volição: uma manifestação da vontade de determinado ser humano em relação ao mundo. Essas quatro perspectivas não podem ser vistas de forma separada (MITCHAM, 1994 apud CUPANI, 2013).

Bunge (1985) define tecnologia como "o estudo científico do artificial", demostrando a relação explícita da tecnologia com o conhecimento científico, porém também revela que para ele o conhecimento tecnológico é um conhecimento diferente do científico. Bunge (1985) também distingue a tecnologia da "ciência básica" e da "ciência aplicada". A ciência básica deseja obter o saber pelo seu valor intrínseco, e a tecnologia persegue a solução de problemas práticos mediante recursos científicos, a ciência aplicada representa essa zona intermediária entre as duas primeiras.

Em outra obra, Cupani (2004) discute a filosofia da tecnologia, com três enfoques, na perspectiva de três autores. O primeiro autor é Mario Bunge, um dos fundadores da disciplina de filosofia da tecnologia. O segundo enfoque é o da fenomenologia, defendido por Albert Borgmann e o terceiro é o de Andrew Feenberg. Nesta obra, Cupani volta a destacar a complexidade da definição e das concepções de tecnologia, destacando que a tecnologia não deve ser vista apenas como ciência aplicada, mas como um tipo específico de conhecimento, um "modo de vida, sobretudo na medida em que esse modo de vida afeta outros modos" (CUPANI, 2004, p. 494).

Mario Bunge (1966, 1980, 1985, 2006), físico e filósofo argentino relatou que a filosofia da tecnologia é um campo de estudo ainda pouco explorado. Ele apresenta uma distinção entre técnica e tecnologia, na primeira a natureza é transformada pelo homem por meio de elementos "pré-científicos" e a segunda consiste na técnica de base científica. 
Técnica e tecnologia estão relacionadas, ambas consistem na produção de algo artificial ou artefato, mas são campos distintos. Algo artificial também pode ser chamado de artefato. $\mathrm{O}$ artefato ou algo artificial não precisa ser um objeto, mas pode ser a modificação de alguma coisa ou transformação de um sistema. O autor cita como exemplo de artefato um medicamento, desviar o curso de um rio, ensinar alguém a ler, etc. De forma geral, a ação técnica utiliza recursos naturais já existentes, modificando-os, para criar algo novo.

Ainda, segundo Bunge, o artefato também pode se transformar em algo social, ou o resultado de um serviço ou algo negativo para a sociedade. Tanto a técnica quanto a tecnologia são caracterizadas por uma "planificação" e tem um objetivo. Para a produção de um artefato, utilizam-se conhecimentos já disponíveis ou criam-se novos conhecimentos. Para a produção de artefatos, a "técnica serve-se do saber vulgar tradicional, eventualmente impregnado de saber científico que não é reconhecido como tal. A tecnologia recorre explicitamente ao saber científico (dados, leis, teorias)" (BUNGE, 1969 apud CUPANI, 2004, p. 495).

Para Bunge (1985), a técnica tornou possível o desenvolvimento humano e a tecnologia acelerou esse progresso. Nesse sentido, a tecnologia surge para "aplicar conhecimentos científicos à solução de problemas práticos”. Dessa forma, Bunge define tecnologia como sendo:

O campo de conhecimento relativo ao desenho de artefatos e à planificação da sua realização, operação, ajuste, manutenção e monitoramento à luz do conhecimento científico. Ou, resumidamente: o estudo científico do artificial (BUNGE, 1985, p. 231).

O autor defende a chamada "filosofia analítica da tecnologia", a qual busca compreender a tecnologia como um "campo de conhecimento" e é fundamentada pelo uso do conhecimento científico com valores, normas, regras, métodos e teorias próprias de seu campo. Ela utiliza e desenvolve conhecimentos já existentes ou cria novos conhecimentos. O “desenho" é definido pelo autor como: "a representação antecipada de um artefato com o auxílio de algum conhecimento científico" (BUNGE, 1985, p. 225). Entretanto, apesar de se utilizar de conhecimentos científicos, para o autor, a tecnologia não é apenas a utilização desses conhecimentos, ela não se resume à ciência aplicada. A tecnologia necessita da busca de um conhecimento específico, surgindo as "teorias tecnológicas". Esse conhecimento 
específico pode ser derivado da fusão de conhecimentos científicos e conhecimentos não científicos.

Em relação às teorias tecnológicas, Bunge (1966) as classifica em dois tipos: substantivas e operativas. As teorias tecnológicas podem ter influência na ação, porque fornecem conhecimento sobre a ação de artefatos tecnológicos, como por exemplo o conhecimento sobre máquinas ou porque fornecem conhecimento sobre ações que dependem de artefatos, como por exemplo o conhecimento sobre o uso de máquinas. Ambas são teorias tecnológicas. A teoria substantiva proporciona conhecimento sobre a ação tecnológica, por exemplo, uma teoria sobre o vôo. A operativa trata da ação que depende do funcionamento de artefatos tecnológicos, por exemplo, uma teoria sobre a distribuição do tráfego aéreo em uma região.

Bunge (1980) destaca que a ciência, por ser o motor da tecnologia, controla a economia dos países e tanto a tecnologia como a ciência fazem parte da cultura contemporânea. Portanto, para se compreender a sociedade moderna é necessário estudar o mecanismo da produção científica e tecnológica. É destacada a importância de se discutir sobre filosofia da tecnologia e destaca que muitos filósofos confundem a ciência com a tecnologia, deixando-se de lado as peculiaridades de cada uma.

Segundo Bunge (1980), é considerado uma tecnologia se "é compatível com a ciência contemporânea e controlável pelo método científico" e se "é empregado para controlar, transformar ou criar coisas ou processos, naturais ou sociais” (BUNGE, 1980, p. 186). Desse ponto de vista, uma tecnologia utiliza os conhecimentos científicos e é a criação de algo novo, um artefato ou processo.

Além do conhecimento científico, a pesquisa tecnológica também cria novos conhecimentos e também pode utilizar conhecimentos do artesanato e da pseudociência. Do ponto de vista metodológico, a pesquisa tecnológica é semelhante à investigação científica, embora tenham metas diferentes. A investigação científica busca uma explicação para determinado acontecimento e a investigação tecnológica busca uma utilidade, algo útil a alguém, uma aplicação (BUNGE, 1980).

Bunge (1985) também supõe uma possível "engenharia social", na qual o conhecimento científico seria utilizado para auxiliar nos problemas sociais. Apesar disso, Bunge é contrário à ideia de que a tecnologia é apenas boa para a sociedade. A tecnologia, 
dessa forma, não é considerada neutra, mas está controlada com base na sociedade. O autor também defende uma democratização da tecnologia, onde todos pudessem ter acesso ao desenvolvimento tecnológico. Bunge conclui que a tecnologia é uma forma evoluída da técnica.

Bunge (1985) também faz uma comparação entre o método tecnológico e o método científico. $\mathrm{O}$ autor defende a existência de uma metodologia básica válida para os processos de investigação, que no caso da tecnologia seria: "problema prático - projeto - protótipo eventual correção do projeto ou reformulação do problema" (BUNGE, 1985, p. 232). Isso seria uma sequência lógica mínima para um processo tecnológico. Dessa forma, para o autor, o projeto é algo central no método tecnológico e não existe um método único para projetar.

Para os propósitos desta pesquisa, assume-se que a abordagem de Mario Bunge oferece um ponto de partida consistente para a discussão acerca da tecnologia. Baseado nesse autor defende-se que a tecnologia é um campo de conhecimento, diferente da ciência. Também se defende que a tecnologia não é meramente a ciência aplicada. Alguns autores fazem críticas às ideias de Bunge, dizendo que ele considera a tecnologia como uma simples aplicação da ciência, porém o autor deixa claro em algumas obras que a tecnologia utiliza conhecimentos científicos, mas não se resume a isso. Para Bunge (2006, p. 375) "a tecnologia não deve ser confundida com a ciência aplicada que é, na realidade, a ponte entre ciência básica e tecnologia, uma vez que ela busca novo conhecimento com potencial prático". Portanto, para o autor, a tecnologia não se resume a conhecimentos científicos, mas procura e produz conhecimentos específicos. Em suas ideias a tecnologia é baseada na ciência e é aperfeiçoada por pesquisas.

De acordo com Cupani (2004, 2006, 2013), parece haver dois pontos de consenso na literatura que defendem uma filosofia da tecnologia: o primeiro, que a tecnologia não é mera ciência aplicada e o segundo, que a tecnologia é um modo específico de conhecimento.

Outra abordagem apontada por Cupani (2004) é a fenomenológica de Albert Borgmann. Para esse autor a tecnologia é um "modo de vida" moderno, que passa despercebido, pois faz parte da vida cotidiana. Segundo Borgmann (1984) a tecnologia é um fenômeno básico, que funciona com a existência de dispositivos que nos fornecem produtos. Dessa forma, os dispositivos seriam um meio para se chegar nos produtos. Como exemplo, o autor cita o aquecedor elétrico e a sua função seria nos dar calor. A função do dispositivo é 
resolver algum problema, tornando a vida do homem mais fácil e diferentes dispositivos podem ter a mesma função. Os produtos e o consumo dos produtos são o objetivo da tecnologia.

Nesse contexto, para Borgmann (1984), surge a propaganda como uma forma de divulgar o consumo, levando as pessoas a consumir cada vez mais produtos tecnológicos. Borgmann traz uma reflexão a respeito do consumismo e de certas coisas que foram perdidas com a tecnologia. Nesse caso, o autor coloca que a busca por uma vida mais fácil, com a inserção da tecnologia, tem levado os seres humanos a abandonar um estilo de vida mais natural, a um lazer oriundo do consumo desenfreado de produtos tecnológicos e está tornando as pessoas presas à tecnologia. Diante disso, o autor propõe uma reforma da tecnologia, partindo do reconhecimento daquilo que ela faz perder. Essa reforma não consiste em eliminar a tecnologia das vidas das pessoas, mas refletir sobre as suas implicações na sociedade.

Assim como Borgmann (1984) acredita que a sociedade está presa à tecnologia, Hanna Arendt também lança uma reflexão semelhante ao dizer que os homens estão condicionados pelas máquinas, ou seja, o homem criou as máquinas para servi-lo, mas o contrário também pode estar ocorrendo. Essas ideias podem levar a uma reflexão sobre o papel da tecnologia e dos artefatos tecnológicos na sociedade.

Um último autor apontado por Cupani (2004) que trata do assunto da tecnologia é Andrew Feenberg, que defende a perspectiva crítica da tecnologia. Esse enfoque sobre tecnologia é defendido por Feenberg em sua obra "Transforming technology" (2010). A tecnologia, para o autor, é um fenômeno da modernidade que está ligado ao capitalismo, e que, além de não ser neutra, ainda carrega valores ligados aos empresários, auxiliando a classe dominante a ter o controle da sociedade. As máquinas estariam submetidas aos valores e interesses da classe dominante do capitalismo, a qual ignora as consequências ambientais e controla diversos setores da sociedade. A tecnologia, portanto, é um instrumento de dominação social que o autor classifica como "a principal forma de poder". Como está interligada com a sociedade capitalista, para este autor, é impossível haver uma reforma apenas na tecnologia, mas o autor defende que deve existir uma modificação cultural de toda a sociedade. O primeiro passo para essa modificação cultural é a percepção da situação de dominação que está ocorrendo, levando a movimentos políticos. 
Nesse contexto, Feenberg (2010) propõe uma nova noção de socialismo como uma forma de modificação cultural, analisando criticamente as ideias de Marx e da Escola de Frankfurt. Para o autor, o socialismo não é apenas uma questão política e que deve ser alcançada por meio de uma revolução da classe dominada, mas é uma "transição gradual" para outro tipo de sociedade, onde o socialismo seria uma sociedade que valoriza bens específicos que não são de mercado. Dessa forma, o socialismo não estaria em oposição ao capitalismo, mas representaria uma evolução dos atuais estados de bem-estar social. Feenberg, porém, admite que essa mudança não seja algo fácil e rápida.

Gilbert (1995) nos mostra que não há um consenso na literatura tanto para definir tecnologia quanto para definir educação tecnológica. Porém, o autor apresenta dois dos principais significados para a tecnologia, como processo e como produto:

Por um lado, é a soma de conhecimentos e habilidades que são utilizados no
processo para resolver problemas práticos que são importantes para a humanidade,
por exemplo, a confecção de um vestuário adequado. Além disso, também
representa objetos ou sistemas que são o resultado desses esforços, por exemplo, as
roupas produzidas (GILBERT, 1995, p. 15).

Gilbert (1995) apresenta as ideias de Pacey (1983) que considera a tecnologia sobre três aspectos: técnico, que trabalha com os conhecimentos e capacidades para a produção de novos produtos; cultural, que envolve os valores subjacentes aos problemas e necessidades que se busca resolver com a tecnologia; e o aspecto organizativo que envolve a sociologia da tecnologia e o uso dos seus resultados. E, para Gilbert (1995), a concepção mais ampla de educação tecnológica é a que engloba esses três aspectos.

Apesar de tantas definições diferentes, para Cupani (2004, 2006, 2013) fica claro que a tecnologia não é apenas a ciência aplicada, mas um modo específico de conhecimento. Cupani destaca que para compreender o conhecimento tecnológico, primeiramente deve-se deixar de considerá-lo como mera aplicação do conhecimento científico. Nesse sentido todos os estudos expostos anteriormente neste trabalho também concordam com esse ponto.

Como uma forma de diferenciar a tecnologia de ciência aplicada, Cupani (2006) cita o exemplo da invenção da máquina a vapor, que não é o resultado da aplicação de conhecimentos científicos, mas pelo contrário, ela foi criada e posteriormente ainda auxiliou no desenvolvimento da termodinâmica. Cupani (2006) também mostra alguns outros exemplos como as pirâmides e catedrais medievais que não poderiam utilizar conhecimento 
científico no sentido moderno da palavra e algumas drogas, o processo de fermentação, uso de tinturas, etc.

Niiniluoto (1997) acredita que é importante uma diferenciação filosófica entre ciência e tecnologia, criticando assim um termo bastante discutido atualmente: a tecnociência. $\mathrm{O}$ autor acredita que a utilização do termo tecnociência busca diminuir a distinção de ciência e tecnologia. Nesse contexto, o autor critica o termo e acredita que é importante estabelecer importantes diferenças entre as duas, embora ambas estejam relacionadas.

Diante disso, Niiniluoto (1997) propõe cinco modelos para relacionar ciência e tecnologia: a tecnologia se subordina à ciência e ela depende ontologicamente da ciência, essa seria a concepção de que a tecnologia é mera ciência aplicada; a ciência se subordina à tecnologia e ela depende ontologicamente da tecnologia, essa concepção sugere que a ciência é apenas um instrumento da tecnologia e é baseada em teorias como o marxismo; ciência e tecnologia são praticamente a mesma coisa, "tecnociência"; ciência e tecnologia são ontologicamente independentes, inclusive no ponto de vista causal; ciência e tecnologia se inter-relacionam causalmente, mas são ontologicamente independentes, onde essa concepção é defendida pelo autor como a mais coerente. $\mathrm{O}$ autor defende que ciência e tecnologia não dependem uma da outra para existir, possuem origens históricas diferentes, mas se interrelacionam, uma influenciando a outra. O autor entende que para ser ontologicamente dependente é necessário que a existência de uma dependa da existência da outra e que uma não exista sem a outra.

Dessa forma, devemos reconhecer a peculiaridade do conhecimento tecnológico, e isso não significa que o conhecimento tecnológico não está associado ao conhecimento científico, mas é necessário reconhecer a peculiaridade de cada um.

Reconhecer a peculiaridade do conhecimento tecnológico significa reconhecer que ele tem sua própria dinâmica, suas próprias regras e formas de funcionar. Os valores sociais também são diferentes entre a ciência e a tecnologia. Utges (1996) busca apontar algumas diferenças entre o conhecimento científico e tecnológico que estão apresentados no quadro 1.

Fundamentação Teórica 
Quadro 1: Diferenciação entre ciência e tecnologia. Fonte: Utges (1996)

\begin{tabular}{|l|l|}
\hline Na Ciência & Na tecnologia \\
\hline Análise de fenômenos & Síntese de uma nova totalidade \\
\hline Abstrato/ teórico & Concreto/ prático \\
\hline Ideia & $\begin{array}{l}\text { Produto/ desenvolvimento de processos es e } \\
\text { implementação }\end{array}$ \\
\hline Investigação & Desenho \\
\hline Ideal (perfeccionismo) & Qualidade máxima possível \\
\hline Tratamento geral de problemas & Resolução de problemas específicos \\
\hline Agente motivador: curiosidade & Agente motivador: necessidade \\
\hline É tratada com suposições & É tratada com fatos \\
\hline Precisão & Tolerância (com o compromisso) \\
\hline Sem laços ou compromissos & Compromisso social e econômico \\
\hline
\end{tabular}

Gilbert (1995) apresenta algumas diferenças entre ciência e tecnologia, como pode ser visto pelo quadro 2 .

Quadro 2: Diferenciação entre ciência e tecnologia Fonte: Gilbert (1995)

\begin{tabular}{|l|l|l|}
\hline $\begin{array}{l}\text { Modelo geral de solução de } \\
\text { problemas }\end{array}$ & Processo científico & Processo tecnológico \\
\hline Entender o problema & Fenômeno natural & Determinar a necessidade \\
\hline Descrever o problema & Descrever o problema & Descrever a necessidade \\
\hline Considerar soluções alternativas & Sugerir hipóteses & Formular ideias \\
\hline Eleger a solução & Selecionar hipóteses & Selecionar ideias \\
\hline Atuar & Experimentar & Desenvolver o produto \\
\hline Avaliar o produto & Relacionar hipóteses/dados & Provar o produto \\
\hline
\end{tabular}

Ainda sobre o trabalho de Gilbert (1995), apresentou-se algumas diferenças entre ciência e tecnologia, como pode ser visto no quadro 3.

Quadro 3: Diferenciação entre ciência e tecnologia Fonte: Gilbert (1995))

\begin{tabular}{|l|l|l|}
\hline CATEGORIAS & CIÊNCIA & TECNOLOGIA \\
\hline Propósito & Explicação & Fabricação \\
\hline Interesse & O natural & O artificial \\
\hline Processo & Analítico & Sintético \\
\hline Procedimento & Simplificação do fenômeno & $\begin{array}{l}\text { Aceita a complexidade da } \\
\text { necessidade }\end{array}$ \\
\hline Resultado & Conhecimento generalizável & Objeto particular \\
\hline
\end{tabular}

Nos três quadros acima, o objetivo foi organizar as principais diferenças entre o conhecimento científico e tecnológico. Observando-se esses trabalhos percebe-se que uma das principais diferenças entre ciência e tecnologia é que à ciência cabe analisar e explicar fenômenos e produzir modelos enquanto a tecnologia possui como objetivo a produção de produtos e processos. Embora a tecnologia utilize conhecimentos científicos, ela não se 
resume a aplicação desses conhecimentos, possui normas e regras próprias e também conhecimentos próprios. Não podemos cair na falsa ideia de acreditar que somente a ciência produz conhecimentos, somente a ciência é responsável por "pensar", pois a tecnologia também é uma forma de produzir conhecimentos.

Veraszto et al. (2008) buscaram, por meio de uma revisão bibliográfica, discutir as principais definições para a palavra tecnologia encontradas na literatura e, a partir dessas concepções, encontrar uma definição própria de tecnologia. A primeira ideia de tecnologia apontada pelos autores é a concepção intelectualista da tecnologia, onde a tecnologia é vista como um conhecimento derivado exclusivamente do conhecimento científico. Essa seria a concepção de tecnologia como ciência aplicada. A segunda seria a concepção utilitarista da tecnologia, onde a tecnologia é vista como sinônimo de técnica. A terceira é a concepção de tecnologia como sendo sinônimo de ciência, na qual ambas seriam a mesma coisa. Outra ideia é a concepção instrumentalista ou artefactual da tecnologia, onde ela é reduzida aos seus artefatos. Outra concepção é a da neutralidade da tecnologia, onde a tecnologia não seria vista como maléfica e nem benéfica, mas dependeria do uso que fazem dela. Na literatura também é encontrada a concepção de determinismo tecnológico, onde a tecnologia é vista como autônoma, fora do controle dos seres humanos. A concepção de universalidade da tecnologia, onde a tecnologia é vista como algo universal, que pode ser útil em qualquer contexto, também é muito comum.

A partir do exposto, percebe-se a complexidade da definição da tecnologia e sua consequente dificuldade para ser discutida no âmbito escolar. Fourez (2003) defende que os alunos deveriam compreender sobre as implicações sociais da tecnologia. Segundo o autor, a compreensão da tecnologia implica considerações sociais, econômicas e culturais que vão muito além da aplicação da ciência e os alunos devem ser capazes de compreender os efeitos organizacionais da tecnologia. Nesse contexto, o autor argumenta que a tecnologia nunca é socialmente neutra e que é de suma importância que os alunos compreendam a complexidade social, cultural, política e econômica da tecnologia.

Segundo Acevedo et al. (2003), dizer que a tecnologia é ciência aplicada significa admitir que o desenvolvimento tecnológico depende hierarquicamente da investigação científica. Para os autores, as relações entre ciência e tecnologia vão além da visão de tecnologia como ciência aplicada. Como exemplo, os autores citam que mais de $90 \%$ da 
investigação sobre os sistemas de armamento dos Estados Unidos em 1966 não representava um desenvolvimento tecnológico baseado na ciência.

Muitos autores admitem que a sociedade vem se modificando devido à tecnologia. Inclusive a cultura hoje é outra devido à presença dos artefatos tecnológicos na sociedade. Portanto, defende-se que hoje vivemos em uma cultura tecnológica.

Para os propósitos deste trabalho, utilizaremos a definição de cultura tecnológica de Quintanilla et al. (2011). O autor apresenta e se baseia no conceito de cultura de Mosterín (1993):

[...] cultura é definida como a informação de representação prática e valorativa que é transmitida por meio da aprendizagem social entre os membros da mesma espécie (MOSTERÍN, 1993 apud QUINTANILLA et al., 2011, p. 3).

Com base nesse conceito, ele destaca três tipos de cultura: informação representacional, informação operacional/prática e informação de avaliação.

A cultura representacional inclui representações, crenças e conhecimentos do mundo natural e social. Contém percepções, opiniões, teorias científicas, crenças religiosas, etc. A cultura operacional/prática inclui regras e normas de comportamento. Contém normas adequadas e inadequadas de comportamento de acordo com cada situação, guiada por costumes de determinada sociedade. A cultura de avaliação consiste em valores e sistemas individuais de preferência. Casos de valores formados de forma explícita e valores individuais e comuns relacionados a contextos específicos são ambos incluídos neste tipo de cultura. Com base nestes conceitos, é possível definir diversos tipos de cultura, como a artística, judicial, religiosa, cultura espanhola, cultura europeia, etc. (QUINTANILLA et al., 2011).

$\mathrm{O}$ autor defende que com base nos conceitos acima estabelecidos, é possível definir também uma cultura científica e tecnológica. Cultura científica seriam as informações de atividades científicas, métodos, resultados científicos relacionados a um grupo social. O termo não se refere à cultura profissional dos cientistas, mas "à parte da cultura de qualquer indivíduo ou grupo de indivíduos relacionados ao conhecimento e atividades científicas" (QUINTANILLA et al., 2011, p. 4).

$\mathrm{O}$ autor também classifica a cultura científica como cultura científica intrínseca e extrínseca. Na cultura científica intrínseca estão os componentes das atividades científicas, como por exemplo, teorias debatidas por cientistas, interpretações científicas, explicações de 
fenômenos, regras científicas, etc. Na cultura científica extrínseca estão incluídas todas as representações de crenças, normas, valores que estão relacionados a atividades científicas e que não estão inclusos na cultura científica intrínseca. Como exemplo pode-se citar a imagem da ciência frente à sociedade, as avaliações da ciência de acordo com fatores culturais, morais, políticos, religiosos e outros pontos de vista (QUINTANILLA et al., 2011).

Quintanilla também caracteriza a cultura tecnológica. Para o autor a cultura tecnológica é:

[...] a informação cultural sobre os sistemas técnicos, o seu funcionamento, design e produção e qualquer outro tipo de atividade relacionada à tecnologia, compartilhada por seus membros (QUINTANILLA et al., 2011, p. 4).

Ela não se refere apenas a tecnólogos e engenheiros, mas a cultura relacionada com a tecnologia, suas invenções, produção, difusão e uso por um determinado grupo social ou indivíduo. Neste contexto, também é possível distinguir entre cultura tecnológica intrínseca e extrínseca. A cultura tecnológica intrínseca está relacionada aos conhecimentos, normas e valores relacionados com o funcionamento de um sistema tecnológico, ou seja, toda a informação necessária para projetar, produzir e usar corretamente um dispositivo técnico. $\mathrm{Na}$ cultura tecnológica extrínseca estão todas as crenças, valores e atitudes que estão relacionadas ao sistema tecnológico. Como, por exemplo, as opiniões sobre a relação das tecnologias de informação com a diminuição dos empregos na indústria, isso afeta a percepção das pessoas sobre tecnologia, mas não o funcionamento da tecnologia (QUINTANILLA et al., 2011).

Faz parte da cultura tecnológica intrínseca: informações sobre o conhecimento tecnológico, regras de uso do sistema tecnológico e valores internos relacionados com a tecnologia. Faz parte da cultura tecnológica extrínseca: imagens que as pessoas possuem da tecnologia, interesses da tecnologia, normas de comportamento relacionadas à tecnologia, avaliações e atitudes relacionadas à tecnologia, imagens positivas, negativas da tecnologia ou neutras da tecnologia (QUINTANILLA et al., 2011).

Para os propósitos deste trabalho utilizaremos também a definição de tecnologia defendida por Mario Bunge, onde ela é vista como o estudo científico do artificial. Ela está diretamente relacionada com o conhecimento científico, porém não pode ser vista apenas como uma aplicação deste, pois é produtora de conhecimentos próprios de sua área de estudo. 


\subsection{Livro Didático}

A preocupação com os livros didáticos no Brasil se iniciou com a Legislação do Livro Didático, em 1938 pelo Decreto-Lei 1006 (FRANCO, 1992). No Brasil, os livros didáticos correspondiam, no início do século $\mathrm{XX}$, a dois terços dos livros publicados e representavam ainda em 1996, aproximadamente 61\% da produção nacional (GATTI, 2000). Hoje, mesmo com o avanço dos artefatos tecnológicos, o livro didático ainda é um instrumento de grande utilização na educação básica, sendo um material de forte influência na prática de ensino, como um auxílio aos alunos e professores. Segundo Vasconcelos e Souto (2003), o livro didático deve promover a reflexão do aluno sobre a sociedade que ele está inserido e desenvolver a capacidade de investigação do aluno, tornando-o capaz de assumir o controle da sua própria aprendizagem. O livro deve ser contrário à “concepção bancária", desenvolvendo a autonomia do aluno.

Dessa forma, é atribuído ao livro didático que ele possa auxiliar os alunos na formação para a cidadania, levando o aluno a se questionar sobre a sociedade a que pertence e trazer discussões de assuntos referentes ao cotidiano e à sociedade. Nesse contexto, um livro didático de qualidade assume um papel fundamental na formação de alunos mais críticos e participativos.

Considerando o baixo poder aquisitivo de muitas famílias brasileiras, muitos alunos podem não ter acesso a outros tipos de livros, fazer pesquisas na internet, ou outras fontes. Nesses casos, o livro didático pode ser "o único material utilizado pelos alunos para aprender conceitos científicos" (MARTORANO; MARCONDES, 2009, p. 342). Por ser um material importante para consulta de alunos e professores, algumas vezes sendo o principal material de apoio do professor e do aluno, é importante que os livros didáticos estejam sempre atualizados e com informações importantes para o cotidiano do aluno. Considerando a importância do livro didático, todos os alunos matriculados em uma escola pública e alguns alunos de escolas privadas recebem livros didáticos e os mesmos servem como base e fonte de busca e consulta.

Além de uma importante fonte de consulta para o aluno, segundo Choppin (2004) os livros didáticos assumem múltiplas funções, entre elas: função referencial, função instrumental, função ideológica e cultural e função documental. Para o autor, o livro didático

Fundamentação Teórica 
assume essas quatro funções, dependendo do contexto em que é utilizado ou várias funções concomitantemente (CHOPPIN, 2004).

Na função referencial, o livro exerce a função de programa escolar ou a interpretação do programa; ele se constitui no suporte de conteúdos, técnicas e habilidades que se deseja transmitir às futuras gerações. Na função instrumental, o livro didático assume o papel de colocar em prática os métodos de aprendizagem, propondo exercícios e atividades. A função ideológica corresponde à função mais antiga do livro didático e nela o livro assume um importante papel político; neste caso o livro didático, de forma explícita ou implícita, é uma forma de transmissão da cultura, da língua e dos valores da classe dominante. Na função documental, o livro didático assume o papel de fornecer um conjunto de documentos para desenvolver o espírito crítico no aluno; neste caso, não são todos os livros didáticos que assumem essa função, apenas aqueles que privilegiam a iniciativa pessoal e a autonomia do aluno (CHOPPIN, 2004).

Nesse contexto, com todas essas funções, o livro didático torna-se de fundamental importância para alunos e professores. No caso do professor, ele serve como auxílio para o planejamento das aulas, sugestão de exercícios e atividades, consulta e aporte para conceitos científicos. Os professores utilizam o livro como o instrumento principal que orienta o conteúdo a ser administrado, a sequência desses conteúdos, as atividades de aprendizagem e avaliação para o ensino das ciências (GAYAN; GARCÍA, 1997). Segundo o Guia Nacional do livro Didático 2015:

O livro didático de Química veicula conceitos, informações e procedimentos desse campo científico. Especialmente para o professor, apresenta formas possíveis de ensinar, abordagens metodológicas e concepções de ciência, educação e sociedade (BRASIL, 2014, p. 9).

Porém, com um instrumento tão importante, é necessário estar atento ao conteúdo do livro didático e às concepções que ele apresenta, conhecer previamente a abordagem e os métodos utilizados, as ideias e concepções vinculadas pelo livro e os conceitos apresentados.

Os livros didáticos são adquiridos e distribuídos pelo FNDE (Fundo Nacional de Desenvolvimento da Educação) e, antes da aquisição do livro ele passa por um processo de avaliação para que possa ser utilizado nas escolas. O Ministério da Educação (MEC) iniciou, por meio do Programa Nacional do Livro Didático (PNLD) uma avaliação criteriosa para garantir a qualidade dos livros adquiridos e posteriormente distribuídos nas escolas públicas. 
Os livros são avaliados por especialistas da área de ensino de ciências e, em seguida, é publicado o Guia do Livro Didático (GLD), um documento que contém os critérios de avaliação dos livros, a divulgação dos livros aprovados e uma resenha crítica de cada livro didático aprovado. Esse documento visa a auxiliar os professores na escolha dos livros didáticos, fornecendo-lhes informações sobre as coleções selecionadas.

Antes dessa avaliação mais criteriosa, a abordagem dos livros didáticos era, muitas vezes, pautada na memorização, com termos e definições pouco compreensíveis e não relacionados ao cotidiano dos alunos. Os livros também contavam, muitas vezes, com ideias preconceituosas e discriminatórias, propagandas e doutrinação religiosa (VASCONCELOS; SOUTO, 2003). Por essas razões tornou-se fundamental criar avaliações e discutir o conteúdo dos livros didáticos, dessa forma as pesquisas sobre livros didáticos cresceram muito nos últimos 30 anos (CHOPPIN, 2004).

O PNLD foi muito importante para a melhoria na qualidade dos livros didáticos. Segundo Vasconcelos e Souto (2003), a criação do PNLD foi um grande avanço, pois está contribuindo para livros com menos erros conceituais, com conteúdos atuais e mais adequados à aprendizagem dos alunos.

Entretanto, apesar de passar por uma avaliação, muitos livros didáticos ainda podem apresentar conceitos errôneos, incoerências, contribuir para a formação de concepções alternativas, ideias errôneas sobre ciência, natureza da ciência e tecnologia ou outras falhas. Portanto, torna-se fundamental que sejam realizadas pesquisas de análise de livros didáticos. Segundo Santos (2001) é importante analisar os livros didáticos para compreender que eles não estão sempre corretos.

Sem pesquisas de avaliação dos livros, corre-se o risco de muitos livros didáticos serem distribuídos sem a certeza do mesmo passar informações, concepções e conhecimentos corretos. A importância das pesquisas não é apenas para alertar a comunidade escolar dos possíveis erros nos livros didáticos, mas também para discutir o conteúdo do livro, suas potencialidades, as ideias, concepções e abordagens que podem ser veiculadas aos alunos. Além das pesquisas, é preciso que os professores estejam atentos à qualidade, à coerência e a eventuais restrições que apresentem em relação aos livros didáticos. Essa análise dos professores é de fundamental importância, não apenas para encontrar erros conceituais nos livros, mas para refletir sobre qual livro se adapta melhor ao seu planejamento e aos objetivos.

Fundamentação Teórica 
Em relação à prática docente, o livro didático não deve ser visto como um manual a ser seguido. Embora seja uma ferramenta que facilite a atividade do professor, não deve ser o centro das atividades de ensino, mas um material de apoio. É importante considerar também que o livro didático não deve ser o único material a ser utilizado, pois a variedade de fontes de informação é que contribuirá para o aluno ter uma visão ampla do conhecimento. A coexistência de diversos instrumentos de ensino-aprendizagem nas aulas estabelece com o livro relações de concorrência ou de complementaridade e é muito importante para a aprendizagem (CHOPPIN, 2004).

Devido a todos esses aspectos, é necessária a escolha de um livro didático que atenda às necessidades do aluno na compreensão do seu cotidiano. Dessa forma, o ensino poderá contribuir na formação de um indivíduo crítico, pensante e não apenas reprodutor de conhecimento. A função que o livro didático pode exercer e todas as suas contribuições só serão possíveis caso se leve em conta o contexto em que o livro é utilizado. Por isso, tanto na escolha quanto no uso do livro, o professor tem o papel imprescindível de adequar e repensar a utilização desse instrumento na sua prática pedagógica, no seu planejamento e às necessidades do seu aluno.

O processo de avaliação dos livros didáticos de todas as disciplinas do ensino médio acontece a cada três anos. As disciplinas do ensino fundamental também têm seus livros avaliados a cada três anos, porém em ano diferente das disciplinas do ensino médio. Trienalmente, o Ministério da Educação lança um edital contendo orientações para os livros didáticos, com os critérios de análise. Posteriormente as editoras se inscrevem e os livros são avaliados por professores especializados de cada disciplina.

Cada coleção é avaliada por uma dupla de especialistas, baseados em critérios previamente estabelecidos no edital. Cada um dos especialistas faz uma análise da obra de maneira individual, em seguida, a avaliação é realizada pela dupla, em conjunto. Para a avaliação ser realizada pelos especialistas, as informações da coleção não são divulgadas, é realizada a avaliação às cegas. Portanto, os avaliadores não sabem os detalhes da obra, como o autor, título, detalhes da editora, etc. Após a avaliação, os especialistas responsáveis escrevem um relato das suas considerações sobre os livros.

O livro didático é avaliado segundo três critérios básicos: a falta de erros conceituais; a coerência teórico-metodológica no conteúdo e nas atividades propostas; e a contribuição para 
a cidadania, sem expressar preconceito, doutrinação ou publicidade (VASCONCELOS; SOUTO, 2003). Entre os critérios norteadores para a avaliação, estão critérios eliminatórios comuns, que são:

[...] o respeito à legislação, às diretrizes e às normas oficiais relativas ao ensino médio; à observância de princípios éticos necessários à construção da cidadania e ao convívio social republicano; à coerência e à adequação da abordagem teóricometodológica assumida pela coleção, no que diz respeito à proposta didáticopedagógica explicitada e aos objetivos visados; à correção e à atualização de conceitos, informações e procedimentos; à adequação da estrutura editorial e do projeto gráfico aos objetivos didático-pedagógicos da coleção. (BRASIL, 2014, p. $13)$.

Para que o livro didático seja submetido à avaliação, também é necessário que ele apresente um manual do professor. O manual do professor deverá conter orientações aos professores de como trabalhar com o livro didático e sugestões de metodologias e atividades que podem ser realizadas. O manual do professor também é avaliado pelo PLND e o livro pode ser reprovado caso o manual não esteja de acordo com os requisitos previamente estabelecidos.

Após passar por todo o processo de avaliação, os livros aprovados serão encaminhados às escolas para que os professores façam a escolha do livro mais apropriado para ser usado naquele contexto.

No GLD estão descritos os livros aprovados pelo MEC, com uma resenha de cada coleção. O GLD é um guia para professores e interessados em conhecer o processo de avaliação dos livros. Neste guia, disponível na internet, há informações apenas das obras aprovadas na avaliação realizada. Encontram-se presentes descrições de como são realizadas as avaliações dos livros didáticos inscritos pelas editoras no PNLD, os critérios de avaliação dos livros, uma resenha de cada obra aprovada e orientações para os professores.

Na avaliação do PNLD de 2015 foram inscritas 13 coleções de livros didáticos de química, de diferentes autorias e diferentes editoras. Dessas coleções, quatro foram aprovadas e nove foram excluídas. As coleções inscritas não são divulgadas, apenas são divulgadas as coleções aprovadas e o número de inscritos.

Os professores farão a escolha dos livros de acordo com o contexto em que se encontram e o Ministério da Educação fica responsável pela compra e distribuição dos livros didáticos aos alunos e professores. Os professores são orientados a escolherem livros presentes no GLD, ou seja, que foram aprovados pela avaliação realizada. Isso ocorre porque 
o Ministério da Educação não se compromete a comprar livros que não foram aprovados na avaliação, portanto, se o professor escolher algum livro não aprovado, o MEC não realizará a compra do material.

Mesmo com tantos documentos que podem auxiliar o professor na escolha do melhor livro didático, é inegável que o professor da Educação Básica tem dificuldade em selecionar esses livros. Essa dificuldade existe mesmo com a criação do GLD. O professor, muitas vezes, tem dificuldade em interpretar o GLD, em fazer uma análise criteriosa do livro didático e outras leituras direcionadas à análise de livros didáticos. Essa dificuldade também pode estar relacionada com falhas na formação inicial e continuada dos professores, que não foram preparados adequadamente para tal tarefa, com as condições precárias de trabalho do professor, falta de tempo para que o mesmo possa fazer uma análise criteriosa do material, entre outros fatores. Os professores também podem ter dificuldades com o próprio conteúdo específico trabalhado no livro, tornando-se difícil analisar se os conceitos presentes no livro estão ou não corretos, afinal o próprio professor pode ter dúvida em relação aos conceitos. Dessa forma, torna-se difícil a escolha do professor pelo livro didático mais adequado ao seu planejamento, muitas vezes, levando-o a escolher o livro de forma aleatória ou a coleção mais conhecida.

Assim, este trabalho buscará fazer uma análise dos livros didáticos de Química do ensino médio. Para a escolha dos livros didáticos, foi consultado o Guia de Livros Didáticos de 2015 (BRASIL, 2014) do PNLD 2015, observando a abordagem da tecnologia durante os capítulos. Isso terá como finalidade discutir quais são as concepções de tecnologia presentes nesses livros, e discutir possíveis inadequações, potencialidades, abordagens inovadoras e dificuldades encontrados nesses livros didáticos quanto à abordagem da tecnologia.

Fundamentação Teórica 


\section{ASPECTOS METODOLÓGICOS DA PESQUISA}

A pesquisa foi estruturada no referencial metodológico de abordagem qualitativa. Segundo Lüdke e André (1986), a pesquisa qualitativa consiste no contato direto e prolongado do pesquisador com o objeto que está sendo investigado, neste caso o livro didático.

Lüdke e André (1986) apresentam as principais características da pesquisa qualitativa: A pesquisa qualitativa tem o ambiente natural como sua fonte direta de dados e o pesquisador como seu principal instrumento. Os dados coletados são predominantemente descritivos. A preocupação com o processo é muito maior do que com o produto.

Realizou-se uma pesquisa documental que, segundo Lüdke e André (1986) pode ser uma técnica muito importante de análise na abordagem qualitativa, seja complementando outros dados ou constituindo dados novos. Lüdke e André (1986) considera que documentos são fontes escritas que podem nos ajudar a compreender o comportamento humano. No nosso caso, esta pesquisa consiste na análise documental e considera como os documentos de interesse os livros didáticos, o guia do livro didático, os editais do PNLD, artigos de periódicos da área e os documentos oficiais da área de ensino de ciências. Na pesquisa documental buscam-se informações em documentos, procurando responder questões de interesse da pesquisa.

Lüdke e André (1986) expõem uma série de vantagens da análise documental. Entre as vantagens citadas aparecem que os documentos podem constituir uma fonte rica e estável de informações; podem ser consultados diversas vezes e servir de base para outros estudos posteriores, dando mais confiabilidade aos resultados; podem ser uma fonte de informação contextualizada, pois os documentos possuem um determinado contexto e podem fornecer informações sobre o contexto; têm baixo custo, geralmente requerem apenas tempo e atenção do pesquisador; consistem numa fonte de dados não-reativa, podendo o pesquisador ter acesso aos dados mesmo quando não se tem acesso direto com o sujeito.

Primeiramente realizou-se uma pesquisa bibliográfica consultando os periódicos nacionais da área de ensino de ciências, visando a observar o que os mesmos apresentam sobre tecnologia. Essa pesquisa bibliográfica serviu de apoio para as demais etapas da pesquisa e para refletir-se sobre a criação de categorias de análise.

Aspectos Metodológicos 
Após essa etapa, analisou-se o documento resultante do processo de avaliação dos livros didáticos, o Guia do Livro Didático. Na análise do Guia, observou-se como o Guia aborda a questão da tecnologia, visando a fornecer ideias sobre o que se pode esperar a respeito da análise dos livros didáticos. O Guia é um documento muito importante, pois contém resenhas dos livros didáticos aprovados, então com ele podemos ter uma ideia prévia do que encontrar nos livros didáticos. Além do Guia, também realizou-se a análise dos editais do PNLD, visando a compreender melhor como ocorre o processo para a seleção dos livros didáticos a serem utilizados e quais os critérios utilizados para fazer a seleção de livros didáticos de Química.

Também realizou-se a análise dos documentos oficiais da área de ensino de ciências. Os documentos analisados foram: Parâmetros Curriculares Nacionais para o Ensino Médio PCNEM (BRASIL, 1999), PCN+ Ensino Médio: Orientações Educacionais Complementares aos Parâmetros Curriculares Nacionais (BRASIL, 2002), Orientações Curriculares para o Ensino Médio (BRASIL, 2006), Diretrizes Curriculares Nacionais da Educação Básica DCNEB (BRASIL, 2013) e Base Nacional Comum Curricular - BNCC (BRASIL, 2016). Tais documentos foram analisados em relação a como eles abordam a questão da tecnologia e à importância da tecnologia para a Educação Básica.

Na sequência realizou-se a análise dos livros em questão. Para a escolha dos livros didáticos recorreu-se ao Guia do Livro Didático de 2015 (BRASIL, 2014) que contém os livros aprovados pela avaliação do Programa Nacional do Livro Didático (PNLD 2015, quadro 4). O Guia apresenta as resenhas dos livros aprovados no processo de avaliação trienal realizado pelo Ministério da Educação. No processo de avaliação do PNLD 2015 foram inscritas 13 coleções, sendo apenas quatro aprovadas. As coleções aprovadas nesse edital estão apresentadas no quadro 4.

As quatro coleções aprovadas pelo PNLD 2015 são divididas em três volumes por coleção, totalizando 12 livros para análise. Analisou-se os livros didáticos utilizando uma análise tipo análise de conteúdo. Nos capítulos buscou-se fazer um levantamento da forma de abordagem do livro no que diz respeito à tecnologia e quais são as concepções de tecnologia presentes nesse material. As concepções foram analisadas com base na literatura envolvendo tecnologia, com a criação de categorias para a análise dos livros didáticos em questão.

Aspectos Metodológicos 
Quadro 4: Livros didáticos aprovados pelo PNLD 2015

\begin{tabular}{|c|c|c|c|}
\hline $\begin{array}{l}\text { Número } \\
\text { da coleção }\end{array}$ & Nome & Autores & Editora e ano \\
\hline 1 & QUÍMICA & $\begin{array}{l}\text { Martha Reis Marques } \\
\text { da Fonseca }\end{array}$ & $\begin{array}{l}\text { Editora Ática } \\
1^{\text {a }} \text { edição } 2013\end{array}$ \\
\hline 2 & QUÍMICA CIDADÃ & $\begin{array}{l}\text { Eliane Nilvana Ferreira de Castro } \\
\text { Wildson Luiz Pereira dos Santos } \\
\text { Gentil de Souza Silva Gerson de Souza Mól } \\
\text { Roseli Takako Matsunaga } \\
\text { Salvia Barbosa Farias Sandra Maria de } \\
\text { Oliveira } \\
\text { Santos } \\
\text { Siland Meiry França Dib }\end{array}$ & $\begin{array}{l}\text { Editora AJS } \\
2^{\mathrm{a}} \text { edição } 2013\end{array}$ \\
\hline 3 & QUÍMICA & $\begin{array}{l}\text { Eduardo Fleury Mortimer } \\
\text { Andréa Horta Machado }\end{array}$ & $\begin{array}{l}\text { Editora Scipione } \\
2^{a} \text { edição } 2013\end{array}$ \\
\hline 4 & $\begin{array}{l}\text { SER } \\
\text { PROTAGONISTA - } \\
\text { QUÍMICA }\end{array}$ & Murilo Tissoni Antunes & $\begin{array}{l}\text { Edições SM } \\
2^{\mathrm{a}} \text { edição } 2013\end{array}$ \\
\hline
\end{tabular}

Todos os dados foram analisados por meio da análise de conteúdo, que segundo Triviños (1987 p. 21) é: "uma técnica de pesquisa para fazer inferências válidas e replicáveis dos dados para o seu contexto".

Segundo Moraes (1999) a análise de conteúdo é uma metodologia de pesquisa usada para interpretar o conteúdo de documentos e textos. A análise pode utilizar descrições qualitativas ou quantitativas, reinterpretando as mensagens e podendo atingir uma compreensão de seus significados num nível que vai além de uma leitura comum. Ou seja, a análise de conteúdo é um método para investigar o significado do conteúdo dos dados. Bardin (2009) define a análise de conteúdo como:

Um conjunto de técnicas de análise das comunicações visando obter, por procedimentos sistemáticos e objetivos de descrição do conteúdo das mensagens, indicadores (quantitativos ou não) que permitam a inferência de conhecimentos relativos às condições de produção/recepção (variáveis indefinidas) destas mensagens (BARDIN, 1995, p. 42)

Dessa forma, Bardin (2009) nos apresenta a análise de conteúdo como uma forma de estudar o conteúdo das mensagens. Tentou-se buscar a explicação para o conteúdo explícito 
dos dados e o conteúdo implícito. O trabalho de análise de conteúdo é qualitativo, mas também buscou-se realizar observações quantitativas em relação ao conteúdo das mensagens.

Neste trabalho utilizou-se a análise de conteúdo para compreender melhor o conteúdo das mensagens do livro didático. Como as mensagens são escritas, pode-se voltar diversas vezes para buscar a compreensão do conteúdo dessas mensagens, buscando-se fazer uma análise dos aspectos implícitos das mensagens.

Analisar os dados qualitativos corresponde a "trabalhar" sobre todo o material disponível. Ao analisar os dados, primeiramente o pesquisador organiza o material em partes menores, analisando cada uma das partes e identificando tendências interessantes para o trabalho. Após isso, analisa-se essas tendências buscando relações entre as tendências e todo o material (LÜDKE E ANDRÉ, 1986). Triviños (1987) estabelece três etapas básicas de análise de conteúdo que foram seguidas no presente trabalho: pré-análise, descrição analítica e interpretação inferencial. Utilizou-se essas três etapas para a análise de conteúdo deste trabalho.

A pré-análise é a organização do material. Nesta etapa realizou-se a leitura do Guia do Livro Didático e dos editais de escolha do livro didático pelo PNLD, buscando compreender melhor a especificidade do material. Também realizou-se pesquisas bibliográficas, aprofundando-se na literatura do assunto, que serviram de aporte para a pesquisa e a leitura dos documentos oficiais, visando a compreender alguns pontos chaves que seriam discutidos na pesquisa. Esta etapa consistiu na leitura geral, buscando-se determinar o campo em que a atenção será fixada.

A descrição analítica é a segunda fase do método de análise de conteúdo. Nesta etapa, após o aprofundamento na literatura e a seleção dos livros a serem analisados, realizou-se uma primeira leitura dos livros didáticos. Utilizando-se as hipóteses e ideias oriundas da literatura, nesta primeira leitura do livro didático foi possível a criação das categorias de análise.

A interpretação inferencial consistiu da leitura mais aprofundada do material, buscando-se revisar as categorias e fazer a análise do mesmo, sempre com base nos objetivos da pesquisa e no referencial teórico adotado.

As categorias aqui apresentadas, foram baseadas em Veraszto et al. (2008), Acevedo et al. (2003) e Quintanilla et. al (2011) e também surgiram de uma primeira análise dos livros 
didáticos, portanto temos categorias criadas a priori e outras posteriormente. As categorias foram divididas em duas famílias de categorias:

- Significado de tecnologia

- Cultura tecnológica

A primeira família de categorias, "significado de tecnologia", se refere a exemplos do livro didático que dão a entender, de forma explícita ou implícita o que o livro entende por tecnologia, qual o seu significado. Dentro dessa família de categorias se encontram dois grupos de categorias: tecnologia como ciência aplicada, ciência como derivada da tecnologia, tecnologia ou técnica e discussão do significado da tecnologia.

As categorias adotadas foram baseadas no trabalho de Acevedo et al. (2003) e Veraszto et al. (2008). Os trabalhos apresentam algumas concepções de tecnologia presentes na literatura. A primeira concepção de tecnologia apontada por Acevedo et al. (2003) é a que apresenta a tecnologia como uma aplicação da ciência. Segundo Acevedo et al. (2003) essa concepção é derivada da filosofia positivista e analista da tecnologia que considera a tecnologia como ciência aplicada. Essa ideia consiste em dizer que a ciência é anterior à tecnologia. Segundo pesquisa realizada por Acevedo et al., a visão de tecnologia como ciência aplicada é a mais comum entre os professores. Veraszto et al. (2008) também expressam que essa concepção está bastante presente na literatura, os autores chamam de Concepção Intelectualista da Tecnologia. Essa visão de tecnologia também está presente em muitos outros trabalhos, como foi visto na revisão dos artigos de revistas brasileiras apresentados no item resultados. A segunda categoria utilizada neste trabalho considera a ciência como derivada da tecnologia. Essa ideia consiste em dizer que a tecnologia é anterior à ciência e essa ideia é apresentada por Acevedo et al. (2003).

A terceira categoria foi baseada em Veraszto et al. (2008) e é apresentada pelos autores como concepção utilitarista da tecnologia. Essa concepção considera a tecnologia como sinônimo de técnica. Neste trabalho essa categoria foi denominada de "tecnologia ou técnica" e abarcará os trechos dos livros didáticos em que a palavra tecnologia e técnica se confundem como sinônimos. A quarta categoria utilizada neste trabalho é "discussão do significado da tecnologia". Essa categoria engloba os trechos do livro em que se apresenta o que é tecnologia e como ela surgiu. Essa categoria surgiu da necessidade de separar os trechos dos livros em que ocorre uma discussão explícita sobre o significado da tecnologia.

Aspectos Metodológicos 
A primeira categoria, que considera a tecnologia como ciência aplicada também conta com quatro subcategorias para dar conta de algumas especificidades. Essas subcategorias surgiram de uma primeira análise dos livros didáticos em que se perceberam diferentes formas de associar a tecnologia como ciência aplicada. As subcategorias são:

- Artefatos tecnológicos que utilizam conceitos, teorias e leis da química.

- Elementos ou substâncias químicas presentes em artefatos tecnológicos.

- Explicação do funcionamento de um artefato tecnológico.

- Modelo linear de desenvolvimento científico e tecnológico.

A segunda família de categorias se refere à cultura tecnológica, baseada no trabalho de Quintanilla et al. (2011). Os autores apresentam o conceito de cultura tecnológica:

A cultura tecnológica de um grupo social é a informação cultural sobre sistemas técnicos, seu funcionamento, projeto, produção e qualquer outro tipo de atividade relacionada com tecnologia, compartilhada por seus membros (QUINTANILLA et al., 2011, p. 5).

Quintanilla também destaca em sua obra o conceito de cultura intrínseca e extrínseca:

Cultura Tecnológica Intrínseca: todo conhecimento, norma de conduta e valores que são imanentes ao projeto, funcionamento ou uso adequado de um sistema técnico. Cultura Tecnológica Extrínseca: toda informação cultural (crenças, normas, atitudes e valores) que estão relacionadas aos sistemas técnicos, atividades ou conhecimentos, bem como as pessoas e instituições que projetam, produzem e difundem tecnologias, mas que não formam parte do sistema tecnológico ou técnico (QUINTANILLA et al., 2011, p.5).

Dessa forma, esses conceitos também serão utilizados para a análise dos dados, sendo criadas mais duas categorias de análise, a de cultura tecnológica intrínseca e extrínseca. Dentro da categoria de cultura tecnológica extrínseca, os exemplos estarão divididos em subcategorias, a saber:

- Pessimismo tecnológico

- $\quad$ Otimismo tecnológico

- $\quad$ Acessibilidade da tecnologia

- $\quad$ Neutralidade da tecnologia

- $\quad$ Tecnologia muda a forma de ver o mundo 
A primeira subcategoria "pessimismo tecnológico" está presente no trabalho de Veraszto et al. (2008) como sendo uma concepção de tecnologia bastante presente na literatura. Essa ideia atribui à tecnologia a culpa por diversos problemas da sociedade atual, como a poluição do meio ambiente, destruição da camada de ozônio, aquecimento global, desemprego, desigualdades sociais, etc. A segunda subcategoria "otimismo tecnológico" também está presente no trabalho de Veraszto et al. (2008). Essa ideia considera a ciência como salvadora da humanidade, capaz de trazer progresso, bem estar à população e melhorar a vida do ser humano. A subcategoria "acessibilidade da tecnologia" surgiu de uma análise preliminar dos dados, onde se percebeu que o livro trazia diversas discussões sobre a acessibilidade da tecnologia e se a tecnologia pode ser considerada como acessível à população ou não. A subcategoria "neutralidade da tecnologia" surgiu do trabalho de Veraszto et al. (2008). A neutralidade da tecnologia considera que a tecnologia não é boa nem má, o uso que fazem dela é que pode ser inadequado. A última subcategoria "Tecnologia muda a forma de ver o mundo" surgiu de uma análise preliminar dos dados em que foi possível analisar vários trechos dos livros didáticos em que consideravam a tecnologia como um fator que modificou a forma das pessoas verem o mundo.

De tal modo, algumas categorias foram criadas com base em uma primeira análise dos dados, emergindo dos próprios resultados do trabalho. Outras categorias foram criadas com base em trabalhos que apresentam concepções de tecnologia presentes na literatura da área. $\mathrm{Na}$ análise dos artigos presentes nos periódicos nacionais de ensino de ciências também foi possível identificar algumas visões de tecnologia. Com base nas categorias descritas acima foram analisadas as quatro coleções de livros didáticos especificados acima. O quadro 5 apresenta as categorias usadas nas análises.

Aspectos Metodológicos 
Quadro 5: Categorias utilizadas nas análises dos livros didáticos

\begin{tabular}{|c|c|c|}
\hline Família de categorias & Categorias & Subcategorias \\
\hline \multirow[t]{7}{*}{ O significado de tecnologia } & \multirow[t]{4}{*}{ Tecnologia como ciência aplicada } & $\begin{array}{l}\text { Artefatos tecnológicos que } \\
\text { utilizam conceitos, teorias e leis da } \\
\text { química }\end{array}$ \\
\hline & & 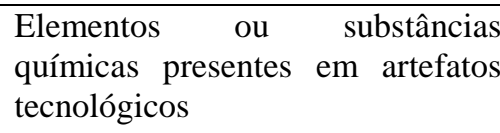 \\
\hline & & $\begin{array}{l}\text { Explicação do funcionamento de } \\
\text { um artefato tecnológico }\end{array}$ \\
\hline & & $\begin{array}{l}\text { Modelo linear de desenvolvimento } \\
\text { científico e tecnológico }\end{array}$ \\
\hline & $\begin{array}{lll}\begin{array}{l}\text { Ciência como derivada } \\
\text { tecnologia }\end{array} & \text { da } \\
\end{array}$ & \\
\hline & Tecnologia ou técnica & \\
\hline & $\begin{array}{llll}\begin{array}{l}\text { Discussão } \\
\text { tecnologia }\end{array} & \text { do } & \text { significado } & \text { da } \\
\end{array}$ & \\
\hline \multirow[t]{6}{*}{ Cultura tecnológica } & Cultura tecnológica intrínseca & \\
\hline & \multirow[t]{5}{*}{ Cultura tecnológica extrínseca } & Pessimismo tecnológico \\
\hline & & Otimismo tecnológico \\
\hline & & Acessibilidade da tecnologia \\
\hline & & Neutralidade da tecnologia \\
\hline & & $\begin{array}{l}\text { Tecnologia muda a forma de ver o } \\
\text { mundo }\end{array}$ \\
\hline
\end{tabular}




\section{RESULTADOS E DISCUSSÕES}

\subsection{A literatura e o Ensino de tecnologia}

Se a quantidade de pesquisas abordando o tema CTS no ensino de ciências já não é tão vasta, as pesquisas que abordam o tema tecnologia com maior destaque são ainda mais escassas. Mesmo com o movimento CTS ainda se atribui à tecnologia um caráter secundário. Gordillo e Galbarte (2002), Maiztegui et al. (2002), Lopes et al. (2009) nos mostram que os currículos e práticas escolares podem acabar deixando a tecnologia em segundo plano. Segundo Ricardo (2015), na escola se ensina apenas ciência; a tecnologia e a sociedade são apenas fontes de temas para problematizar ou aplicar a ciência, ficando a tecnologia como algo secundário. O ensino de tecnologia é visto como uma consequência natural quando se ensina ciência. Maiztegui et al. (2002) acredita que essa subvalorização da tecnologia está relacionada com concepções erradas sobre o que é tecnologia e suas relações com a ciência.

Pode-se perceber que, apesar de ser atribuído à tecnologia o status de algo que deve ser discutido e implementado no contexto escolar, ela ainda é vista como uma fonte de problematização para a ciência e não como uma área de conhecimento com características próprias.

Buscando fazer um levantamento bibliográfico dos trabalhos que abordam a questão da tecnologia, realizou-se uma pesquisa sobre o tema em onze dos principais periódicos nacionais da área de ensino de ciências, com o objetivo de compreender como o tema tecnologia é exposto nesses periódicos. Essa pesquisa permitiu compreender como os pesquisadores abordam e o que pensam sobre o tema tecnologia, com base nos trabalhos científicos ligados às áreas de pesquisa no ensino de ciências. Para a pesquisa foram selecionados os periódicos brasileiros online de acesso livre, que relatam um vínculo com a área de ensino de ciências e que contém artigos de pesquisa da área. A revisão se restringiu aos artigos publicados nos periódicos de Qualis A1, A2 e B1 da área de ensino de ciências visualizados na plataforma Sucupira / Capes do ano de 2015. Foram selecionados onze dos principais periódicos para análise, como mostra o quadro 6 com os periódicos em ordem alfabética.

Resultados e Discussões 
Para selecionar os artigos de interesse, realizou-se uma consulta ao site dos periódicos e buscou-se as três palavras-chave na seguinte ordem: $1^{\text {o }}$ "tecnologia", $2^{\circ}$ "CTS" e $3^{\circ}$ "educação tecnológica". As palavras-chave foram buscadas nos buscadores internos dos periódicos, em todas as seções disponíveis: título, resumo, palavras-chave e texto completo. Os trabalhos selecionados para análise foram os publicados entre 2000 e 2015.

Quadro 6: Lista de periódicos analisados

\begin{tabular}{|l|l|}
\hline Periódico da área de Ensino de Ciências & Qualis/Capes (2015) \\
\hline Alexandria & A2 \\
\hline Caderno Brasileiro de Ensino de Física & A2 \\
\hline Ciência e Educação & A1 \\
\hline Ciência \& Ensino & B1 \\
\hline Ensaio: Pesquisa em Educação em Ciências & A1 \\
\hline Experiências em Ensino de Ciências & B1 \\
\hline Investigações em Ensino de Ciências & A2 \\
\hline Química Nova na Escola & B1 \\
\hline $\begin{array}{l}\text { Revista Brasileira de Ensino de Ciências e e } \\
\text { Tecnologia }\end{array}$ & A2 \\
\hline Revista Brasileira de Ensino de Física & A1 \\
\hline $\begin{array}{l}\text { Revista Brasileira de Pesquisa em Educação } \\
\text { em Ciências }\end{array}$ & A2 \\
\hline
\end{tabular}

Após essa primeira revisão, foi encontrado um número bem extenso de trabalhos que trouxeram as palavras-chave expostas acima, como pode ser visto no quadro 7.

Quadro 7: Número de trabalhos encontrados por revista no período de 2000 a 2015

\begin{tabular}{|l|l|}
\hline Periódico da área de Ensino de Ciências & Número de trabalhos \\
\hline Alexandria & 42 \\
\hline Caderno Brasileiro de Ensino de Física & 47 \\
\hline Ciência e Educação & 72 \\
\hline Ciência \& Ensino & 20 \\
\hline Ensaio: Pesquisa em Educação em Ciências & 25 \\
\hline Experiências em Ensino de Ciências & 69 \\
\hline Investigações em Ensino de Ciências & 32 \\
\hline Química Nova na Escola & 171 \\
\hline Revista Brasileira de Ensino de Ciência e Tecnologia & 31 \\
\hline Revista Brasileira de Ensino de Física & 47 \\
\hline $\begin{array}{l}\text { Revista Brasileira de Pesquisa em Educação em } \\
\text { Ciências }\end{array}$ & 42 \\
\hline
\end{tabular}

Somando todos os periódicos pesquisados, encontrou-se 598 artigos que mencionavam o tema tecnologia, CTS e educação tecnológica. Realizou-se a leitura do resumo de todos os artigos encontrados e no campo de buscas do artigo procurou-se em que contexto o artigo 
mencionava a palavra tecnologia. Dos 598 artigos, apenas 30 abordaram a questão da tecnologia com um pouco mais de ênfase, ou seja, 5\% dos artigos dão alguma atenção à tecnologia. Com isso, podemos perceber que apesar da grande quantidade de trabalhos que abordam CTS ou mencionam a tecnologia, apenas 5\% deles discute realmente sobre a tecnologia.

O critério para a seleção desses 30 artigos foi conter discussões, mesmo que pequenas, sobre tecnologia ou ensino de tecnologia. Foram selecionados os artigos que discutiam de alguma forma a questão da tecnologia, como artigos que discutem o significado de tecnologia, as relações da tecnologia com a cultura, sociedade ou ciência, concepções de tecnologia, apresentam propostas para discutir sobre tecnologia em sala de aula, propostas práticas para aulas sobre tecnologia, discutem a importância da educação tecnológica ou o lugar da tecnologia no movimento CTS. Os artigos que de alguma forma discutiram sobre as especificidades da tecnologia ou sobre educação tecnológica foram selecionados para análise.

Após essa seleção, foi realizada a leitura apenas dos artigos que abordavam a tecnologia com mais ênfase. Os demais artigos foram classificados em: apenas menciona a palavra tecnologia, CTS sem discutir a tecnologia e TIC's sem discutir sobre tecnologia. A tabela 1 mostra a classificação dos artigos encontrados nas revistas que não foram selecionados para análise:

Resultados e Discussões 
Tabela 1: Classificação dos artigos encontrados nas revistas

\begin{tabular}{l|l|l|l|l}
\hline Periódico pesquisado & $\begin{array}{l}\text { Apenas } \\
\text { menciona a } \\
\text { palavra } \\
\text { tecnologia }\end{array}$ & $\begin{array}{l}\text { CTS sem } \\
\text { abordar a } \\
\text { tecnologia }\end{array}$ & $\begin{array}{l}\text { TIC sem } \\
\text { abordar a } \\
\text { tecnologia }\end{array}$ & Tecnologia \\
\hline Alexandria & 23 & 10 & 5 & 4 \\
\hline $\begin{array}{l}\text { Caderno Brasileiro de } \\
\text { Ensino de Física }\end{array}$ & 28 & 4 & 12 & 3 \\
\hline Ciência Educação & 37 & 19 & 9 & 7 \\
\hline Ciência ensino & 6 & 12 & 1 & 1 \\
\hline Ensaio experiências em Ensino & 10 & 8 & 4 & 3 \\
\hline $\begin{array}{l}\text { Expe Ciências } \\
\text { de }\end{array}$ & 92 & 8 & 0 \\
\hline $\begin{array}{l}\text { Investigações em Ensino } \\
\text { de Ciências }\end{array}$ & 22 & 6 & 2 & 2 \\
\hline $\begin{array}{l}\text { Química Nova na Escola } \\
\text { Revista Brasileira de } \\
\text { Ensino de Ciência e } \\
\text { Tecnologia }\end{array}$ & 144 & 15 & 9 & 3 \\
\hline $\begin{array}{l}\text { Revista Brasileira de } \\
\text { Ensino de Física }\end{array}$ & 36 & 11 & 6 & 1 \\
\hline $\begin{array}{l}\text { Revista Brasileira de } \\
\text { Pesquisa em Educação } \\
\text { em Ciências }\end{array}$ & 16 & 18 & 7 & 2 \\
\hline
\end{tabular}

Os artigos que foram classificados como "apenas menciona a palavra tecnologia" foram aqueles que apenas mencionavam a palavra tecnologia, sem discutir ou abordar o tema. Alguns artigos tratavam sobre o tema CTS, entretanto não faziam nenhuma observação sobre como abordar a tecnologia ou especificavam a questão tecnológica. Os artigos sobre TIC's que traziam propostas para o ensino com artefatos tecnológicos como vídeos, computador, simuladores, mas que não discutiam sobre como abordar a tecnologia em sala de aula ou sobre a própria tecnologia, foram classificados na terceira coluna da tabela 1. Na quarta coluna da tabela 1 foram inseridos os artigos que discutem a questão tecnológica, mesmo que de forma superficial e foram selecionados para análise.

Uma tendência geral observada nos artigos, tanto nos selecionados para análise como não selecionados é que, na maioria dos casos, a palavra "tecnologia" aparece sempre ao lado da palavra "ciência". Em uma maioria esmagadora dos artigos essas duas palavras sempre aparecem associadas, como se a expressão "ciência-tecnologia" fosse uma única palavra, um único conceito. Esses casos levam a ideia de que ciência e tecnologia são a mesma coisa e não há qualquer necessidade de uma atenção específica para a tecnologia. A tecnologia é uma dimensão esquecida no ensino, como apontado por Maiztegui et al. (2002) onde é destacado 
não apenas a insuficiente presença da tecnologia no ensino de ciências, mas a falta de reflexões sobre a natureza da tecnologia e o papel da tecnologia nas investigações.

Abaixo segue uma descrição dos artigos selecionados para análise encontrados em cada uma das revistas:

Alexandria: Nessa revista foram encontrados 42 trabalhos que continham a palavra tecnologia. Desses, 23 apenas mencionavam a palavra, porém não discutiam sobre nenhum aspecto da tecnologia. 5 trabalhos dessa revista abordavam o tema Tecnologia da Informação e Comunicação (TIC), porém sem discutir a importância da tecnologia no ensino ou trazer uma discussão a respeito da definição e aspectos históricos e filosóficos da tecnologia. 10 trabalhos dessa revista abordaram o tema CTS, porém deixando a tecnologia como algo secundário, sem discutir o que seria um ensino de tecnologia realmente. Apenas 4 trabalhos abordaram o tema tecnologia de fato. Abaixo apresenta-se um resumo de como cada um desses 4 trabalhos abordou o tema tecnologia.

- La Formación de Ingenieros para la Participación Pública en Ciencia y Tecnologia (2008), Carlos Augusto Osorio Marulanda: o trabalho descreve um curso de formação para estudantes de engenharia que busca formar profissionais mais aptos a discutir sobre temas de ciência e tecnologia. O artigo esclarece a importância de formar pessoas que possam discutir ativamente e tomar decisões sobre temas de ciência e tecnologia e não deixar essas decisões apenas nas mãos de "experts", pois esse tipo de decisão pode influenciar todos os cidadãos. Porém, o texto dá ênfase à discussão de como formar "experts", no caso do artigo em questão, estudantes de engenharia para que durante a sua prática profissional eles possam reconhecer a importância da participação pública em ciência e tecnologia. Dessa forma, os autores discutem características de um curso com enfoque CTS para a formação desses engenheiros, utilizando grupos de discussão envolvendo casos simulados de transgênicos. No curso de formação de engenheiros são discutidas questões sobre os conceitos de técnica, tecnologia e ciência, bem como questões sobre ética, filosofia da ciência e da tecnologia e natureza da ciência e da tecnologia. $\mathrm{O}$ autor também traz três argumentos que defendem a participação da população em questões de ciência e tecnologia. O primeiro é que todas as pessoas têm sua vida afetada, de alguma forma, pela tecnologia e devem participar das decisões sobre ela. $\mathrm{O}$ segundo considera que mesmo pessoas que não são profissionais da área das ciências e 
engenharias podem dar contribuições importantes para essas áreas. O terceiro diz que uma sociedade só será democrática se todos os cidadãos puderem influenciar as decisões sobre o desenvolvimento tecnológico.

- As Percepções na Teoria Sociocultural de Vigotski: uma análise na escola (2012), Marcia Borin da Cunha e Marcelo Giordan: neste trabalho, realizou-se uma pesquisa com 226 estudantes de ensino médio de uma escola pública sobre a percepção de ciência e tecnologia destes estudantes, através de questionários e posterior entrevista com alguns dos participantes da pesquisa. Através do trabalho se percebeu a percepção de ciência e tecnologia dos estudantes, observando a influência da mídia na opinião dos estudantes e que os estudantes buscam poucas informações sobre ciência e tecnologia em diferentes meios de comunicação. Outro ponto importante, é que os estudantes não conseguem separar ciência de tecnologia, acreditando que ambas são a mesma coisa. A visão dos estudantes também é de que a ciência só está presente na vida deles na escola, não enxergando outros momentos em seu cotidiano que ela está presente. Já a tecnologia, os estudantes acreditam que está profundamente presente no cotidiano deles, na forma de artefatos tecnológicos como computadores e celulares, e que ela lhes proporciona uma melhor qualidade de vida. Neste caso, percebemos que a visão dos alunos de ensino médio é da tecnologia como uma "salvadora" da humanidade, encantadora e fascinante, mesmo sem conseguir formular um conceito para ela e compreendê-la mais profundamente. Os únicos conceitos apresentados sugerem que a tecnologia seja uma ramificação da ciência ou resultado dela.

- Contextualização e Visões de Ciência e Tecnologia nos Livros Didáticos de Física Aprovados pelo PNLEM (2010), Cristina Cândida de Macedo e Luciano Fernandes Silva: o objetivo do artigo consistiu em identificar como está ocorrendo a contextualização e a visão de ciência e tecnologia dos livros didáticos de física, aprovados pelo PNLD 2007, a partir do tema Produção de Energia Elétrica em Larga Escala. No trabalho, os autores observam que nos livros didáticos a ciência e a tecnologia são apresentadas como neutras, sem influências sociais, e com uma visão reducionista de que apenas cientistas devem opinar sobre assuntos envolvendo ciência e tecnologia, não sendo apresentada de forma contextualizada e ligada ao cotidiano do aluno. Também é vista nos livros didáticos a ideia salvacionista ou redentora da ciência e da tecnologia e que a tecnologia é algo inevitável, que temos que aprender a conviver, pois não há como voltar atrás. É difundida a visão de que o ensino de ciências, neste 
caso o ensino de física, serve apenas para preparar o aluno para vestibulares e para a formação de cientistas.

- A Ciência Reguladora e Precaucionária na Análise dos Riscos Tecnológicos (2014), Carlos Silva de Jesus, Bruno Stefoni Böck e Álvaro Chrispino: o trabalho se inicia abordando o que seria um ensino CTS. Os autores citam o trabalho de Feenberg (2010) que espera que a tecnologia possa ser controlada pela sociedade e não apenas por especialistas. É destacado que o conhecimento científico é socialmente construído e é necessário ocorrer uma desmistificação da ciência para promover a participação pública nas decisões em relação à ciência e tecnologia. Os autores defendem que vivemos em uma sociedade tecnocientífica, onde ciência e tecnologia seriam interdependentes. Os autores utilizam as ideias de Ortega y Gasset, Mumford, Echeverria, Ferreira e Hughes. Ortega y Gasset (1939) acredita que a técnica e a tecnologia representam a superação do homem à hostilidade do ambiente e explica os três tipos de técnica existentes. Mumford (1934) discute as transformações feitas pelas máquinas na sociedade. Echeverría (1999) distingue as sociedades conforme a influência da tecnologia como natural, cultural, social e urbano e comunicação e informação. Ferreira (2010) aborda a questão de paradigma econômico. Hughes (2008) aborda o conceito de sistemas tecnológicos como o conjunto de componentes para resolver problemas complexos. Em relação aos riscos tecnológicos, é apontado como um problema da sociedade tecnocientífica e são citados exemplos como a poluição, variação climática, radioatividade, etc. A sociedade deve conhecer e ser capaz de tecer considerações sobre esses riscos. Assim, surge a necessidade de participação social, exigindo uma sociedade mais informada sobre os assuntos, que podem ser abordados em um ensino CTS. A ciência reguladora seria incumbida de fornecer conhecimentos e orientar práticas para discutir a tecnologia. $\mathrm{O}$ artigo traz a proposta de se trabalhar ciência, utilizando a questão de riscos tecnológicos.

Caderno Brasileiro de Ensino de Física: Desse periódico, 28 artigos apenas mencionam o nome tecnologia, 11 trabalhos abordam o ensino com a utilização de TICs, 4 trabalhos falam sobre um ensino CTS, negligenciando a tecnologia e 4 trabalhos abordam de forma mais profunda a tecnologia. Os trabalhos são:

- Alfabetização científica e tecnológica e a interação com os objetos técnicos (2006), Silvania Sousa do Nascimento, Robson Santos e Elbert Nigri: o trabalho discute que mesmo com 
várias propostas curriculares para a inserção dos conhecimentos de tecnologia na educação básica, ainda se tem poucos registros práticos de investigação referentes ao assunto. No trabalho são analisados dois grupos de alunos de 9 a 12 anos de uma escola de ensino Fundamental, primeiro ciclo de alfabetização, ao interagirem com a construção de um objeto técnico, um aeromodelo. Discutem-se quais são as possibilidades e limitações desse tipo de atividade e como influencia uma alfabetização científica e tecnológica. Na proposta de atividades, discutiu-se sobre tecnologia e aviões e construiu-se um aeromodelo com os alunos. Concluiu-se do trabalho a importância desse tipo de atividade para o ensino.

- História da ciência e o uso da instrumentação: construção de um transmissor de voz como estratégia de ensino (2011), Enoque Rinaldi e Andreia Guerra: o trabalho discute um projeto de atividade com aparatos históricos, visando a discutir a história da ciência e da tecnologia e a relação entre ambas. $O$ projeto foi realizado com alunos de ensino médio com o desenvolvimento de atividades experimentais, discussão de textos sobre eletromagnetismo e a construção de um transmissor de ondas eletromagnéticas rudimentar. Os autores destacam a importância de se discutir sobre tecnologia e que uma das formas de inserir esse tema é por meio de discussões histórico-filosóficas de como a ciência e a tecnologia se construíram ao longo do tempo e limites e possibilidades desses conhecimentos. As discussões históricofilosóficas giraram em torno do tema eletromagnetismo, levando sempre em consideração o contexto histórico-cultural do assunto. Após a discussão histórico-filosófica, os alunos participaram da construção de um aparato tecnológico, um transmissor de ondas eletromagnéticas e discutiram o funcionamento de alguns artefatos tecnológicos como o rádio e o celular. Os resultados da pesquisa mostraram que os alunos possuem muitas dúvidas e questionamentos referentes à tecnologia e artefatos tecnológicos, os alunos demostraram muito interesse pelo assunto e que é um assunto de muita urgência em ser trabalhado. Com o projeto foi possível que os alunos conhecessem a história dos aparatos tecnológicos, compreendendo melhor a história, a filosofia e a construção da tecnologia. Apesar do projeto trazer uma discussão importante sobre tecnologia, percebe-se que a ideia vinculada é de tecnologia como ciência aplicada, pois ao se abordar os artefatos tecnológicos é discutido os conceitos científicos envolvidos.

- Pensando a natureza da ciência a partir de atividades experimentais investigativas numa escola de formação profissional (2014), Clarice Parreira Senra e Marco Braga: o artigo aborda 
um projeto realizado com alunos de ensino médio de uma escola técnica para a construção de um coletor solar para aquecimento de água, utilizando materiais de baixo custo. Em relação a isso, buscou-se investigar as reflexões sobre ciência e tecnologia dos alunos, por meio de anotações e um grupo focal. Com a construção de um artefato tecnológico pelos alunos, foi possível compreender mais sobre Natureza da Ciência e da Tecnologia, com questões como a construção de protótipos, testes com o artefato tecnológico, construção de um artefato, questões de mercado, etc. Apesar do artigo trazer discussões importantes sobre um projeto de construção de um artefato tecnológico, não há discussão sobre o que é tecnologia, relação entre ciência e tecnologia e questões socioeconômicas da tecnologia.

Ciência e Educação: Os trabalhos que apenas mencionam a tecnologia são 39 artigos, os que discutem o movimento CTS são 19, as intervenções em sala de aula com a utilização de TICs são 9 e as que abordam a tecnologia são 9.

- Visión de profesores en ejercicio respecto de la enseñanza de tecnologia: un estudio en Argentina (2001), Graciela Utges, Alberto Jardón, Luis Feráboli, Patricia Fernández: o trabalho apresenta a visão de professores em relação à tecnologia e seu ensino, a partir de um questionário e prévia entrevista aplicado a 66 professores da educação básica na Argentina. Existem poucos trabalhos abordando o ensino de tecnologia e a tecnologia pode ser abordada de três formas diferentes, como uma disciplina específica, com enxertos CTS em outras disciplinas ou dentro de disciplinas científicas como física, química e biologia. Na Argentina, tecnologia foi inserida no currículo, porém, os autores acreditam que não existem professores preparados para o ensino da mesma. Devido a isso, os autores buscaram investigar a visão de tecnologia desses professores para verificar sua hipótese. A pesquisa foi baseada em um questionário construído pelos autores com base em entrevistas. Os resultados mostram que não existe um consenso entre os professores em como deve ocorrer o ensino de tecnologia e o que é tecnologia, sendo muito distintos um pensamento de outro. Cada professor compreende o ensino de tecnologia de forma diferente e sua aplicação em sala de aula também é distinta. Alguns professores compreendem que a tecnologia deve ser tratada em uma interação com a sociedade e a ciência, enquanto outros acreditam que ela deve ser abordada de forma disciplinar sem discutir suas implicações sociais. O artigo também mostra que os professores possuem uma visão de tecnologia bastante tradicional, como sendo ciência aplicada.

Resultados e Discussões 
- Educação em física: discutindo ciência, tecnologia e sociedade (2001), José André Perez Angotti, Fábio da Purificação de Bastos e Rejane Aurora Mion: o texto aborda a importância de se trabalhar com objetos tecnológicos no ensino de física. Os alunos utilizam objetos tecnológicos diariamente, porém não compreendem seu funcionamento e não problematizam o seu uso. Também é importante que as discussões na escola não se restrinjam na definição de tecnologia, mas sejam discutidas as implicações da tecnologia na sociedade. Os autores também abordam que a população vive em um "sonambulismo", devido à falta de formação escolar adequada para discussões envolvendo ciência e tecnologia. Com base nisso, os autores defendem a utilização de objetos tecnológicos como geradores de discussão em sala de aula, como, por exemplo, o carro, que pode gerar importantes discussões sobre ciência e tecnologia. Os alunos participantes da pesquisa tiveram mais interesse em como os objetos técnicos funcionavam e como eram fabricados. Os autores acreditam que a experiência de se trabalhar com objetos técnicos foi bastante significativa para os alunos, porém faltou aprofundamento em algumas discussões filosóficas e epistemológicas da tecnologia.

- Uma visão comparada do ensino em ciência, tecnologia e sociedade na escola e em um museu de ciência (2001), Guaracira Gouvêa e Maria Cristina Leal: o trabalho analisa a fala de crianças e professores sobre atividades realizadas na sala de aula e em um museu de ciências. Os autores defendem uma educação com enfoque CTS, expondo o seu significado e principais discussões envolvidas. As autoras apresentam a ideia de que a tecnologia sempre teve uma imagem secundária em relação à ciência, porém atualmente ela tem recebido maior destaque, e que ela não pode ser considerada apenas ciência aplicada. Apesar de estar descrito aqui, o artigo aborda muito pouco e de forma superficial a questão da tecnologia.

- Ciência, tecnologia e suas relações sociais: a percepção de geradores de tecnologia e suas implicações na educação tecnológica (2009), Rosemari Monteiro Castilho Foggiatto Silveira e Walter Bazzo: o artigo investiga a visão de pessoas envolvidas com tecnologia (envolvidas com o processo de desenvolvimento de inovações tecnológicas) sobre ciência, tecnologia, inovação e o contexto social. Os envolvidos com tecnologia foram entrevistados sobre o que pensam em relação à ciência, tecnologia, inovação e sociedade (CTS e inovação). As entrevistas foram semiestruturadas e foram realizadas com 29 participantes. Inicialmente, os autores apresentam algumas definições para o termo tecnologia, expostas por Bastos (1998) e Miranda (2002) e discutem a presença da tecnologia na sociedade e sua influência, com base 
em diversos pensadores. Primeiramente, os autores questionaram os participantes da pesquisa em relação à tecnologia e o contexto social e perceberam que os entrevistados mostraram bastante estranhamento na pergunta, expondo que a relação entre tecnologia e sociedade não é tão refletida pelos mesmos. A maioria dos entrevistados percebe que ciência e tecnologia possuem muita influência na sociedade e apontam como uma das diferenças que a tecnologia só é atrativa se tiver retorno comercial e gerar lucro, já a ciência não se preocupa tanto com o lado econômico. Para 13\% dos participantes da pesquisa, ciência, tecnologia e sociedade estão interligadas e não podem ser dissociadas. Grande parte dos pesquisados acredita que a tecnologia é um mal necessário.Com relação a isso os autores argumentam que a tecnologia como conhecemos hoje não é tão antiga, portanto ela não é inerente à sociedade humana, sendo uma opção da sociedade capitalista em que vivemos. Poucos entrevistados expressaram a necessidade de se pensar na sociedade quando o assunto é tecnologia, pensar em tecnologias mais limpas e em tecnologias que possam melhorar a vida da população. Para finalizar, os autores defendem que devemos investir mais em uma educação tecnológica.

- Concepções de tecnologia de graduandos do estado de São Paulo e suas implicações educacionais: breve análise a partir de modelagem de equações estruturais (2013), Estéfano Vizconde Veraszto, Dirceu da Silva, Eder Pires de Camargo e Jomar Barros Filho: a pesquisa foi realizada com graduandos do Estado de São Paulo sobre as suas concepções sobre tecnologia. Os autores levam em consideração a diferença na imagem de tecnologia que é vinculada na mídia, nas universidades e nos documentos oficiais. Dessa forma, não há muito consenso ao definir tecnologia e por isso é importante analisar o que os graduandos pensam em relação à mesma. De acordo com a pesquisa, foi possível perceber que a tecnologia é considerada pelos graduandos como intelectualista e sinônimo de ciência, reforçando ainda mais a ideia de que a tecnologia seria uma aplicação da ciência; instrumentalista, onde seriam considerados apenas os artefatos tecnológicos por ela produzidos; neutra, onde a tecnologia é considerada nem boa nem má, mas depende do uso que fazem dela. Essas concepções dos graduandos, os autores consideraram como limitadas.

- A noção de mobilização na associação da Física a objetos tecnológicos contemporâneos (2015), André Coelho da Silva, Maria José Pereira Monteiro de Almeida: o trabalho aborda a questão do ensino de física no ensino médio utilizando como tema artefatos tecnológicos. $\mathrm{O}$ artigo inicia argumentando a importância do ensino de física se aproximar do cotidiano. Nesse 
caso, os autores utilizam como justificativa para aprender física os objetos tecnológicos presentes em nosso cotidiano. Os autores ainda discutem a definição de tecnologia, defendendo que ela não é neutra e também não é apenas uma aplicação da ciência. Foram analisadas informações de três atividades diferentes, desenvolvidas em sala de aula, sobre objetos tecnológicos, utilizando textos de divulgação científica. Com base nos resultados, os autores acreditam que trabalhar sobre artefatos tecnológicos presentes no cotidiano pode despertar nos alunos o interesse por aprender física, aumentando a motivação dos estudantes.

- Concepções de professores de química sobre ciência, tecnologia, sociedade e suas interrelações: um estudo preliminar para o desenvolvimento de abordagens CTS em sala de aula (2008), Ruth do Nascimento Firme e Edenia Maria Ribeiro do Amaral: o artigo buscou investigar a concepção de professores de química sobre CTS. Foram entrevistados professores de escolas públicas de ensino médio. Os autores defendem que o ensino deve ocorrer em uma perspectiva CTS, portanto é de extrema importância compreender a concepção dos professores sobre CTS. Os resultados mostram que os professores possuem uma compreensão limitada sobre o que seria um ensino CTS, apresentam concepções ingênuas e sugerem uma mudança no processo formativo dos professores. É possível perceber que os professores possuem muita dificuldade para definir tecnologia e acreditam que ela seja uma aplicação de conhecimentos científicos, subproduto da ciência. A tecnologia também é associada com a técnica e acredita-se que o conhecimento científico precede o tecnológico.

Ciência e Ensino: A tecnologia é apenas mencionada em 6 artigos, 2 artigos abordam a questão de TICs, 11 artigos discutem a questão CTS porém apenas 1 trabalho aborda a tecnologia com ênfase.

- De olho no futuro: ficção científica para debater questões sociopolíticas de ciência e tecnologia em sala de aula (2007), Luís Paulo Piassi e Maurício Pietrocola: o artigo busca analisar obras de ficção científica, discutindo questões sociais envolvendo ciência e tecnologia e buscando apresentar caminhos de como essas questões podem ser adaptadas para serem inseridas em sala de aula. Os autores utilizam como exemplo três histórias de ficção científica e como elas podem ser inseridas em sala de aula. Os autores defendem que a ficção científica pode ser usada no ensino, com finalidade educacional. Sobre tecnologia, os autores abordam que histórias de ficção científica podem tornar os alunos mais questionadores em 
relação à tecnologia, muitas ficções científicas levam a reflexões sobre a tecnologia, se ela é maléfica ou benéfica, a vida em um mundo tecnológico, a função da tecnologia na sociedade, etc. Essas reflexões podem tornar o aluno mais crítico em relação à tecnologia.

Ensaio: Nesta revista foram encontrados 25 artigos abordando o tema tecnologia, desses artigos apenas 3 discutiram a tecnologia realmente. 10 artigos apenas mencionam a palavra tecnologia, 4 artigos abordam a questão de TIC's e 8 artigos abordam o tema CTS. Os artigos que abordam a tecnologia com mais ênfase são:

- Uma análise de pressupostos teóricos da abordagem C-T-S (Ciência - Tecnologia Sociedade) no contexto da educação brasileira (2002), Wildson Luiz Pereira dos Santos e Eduardo Fleury Mortimer: os autores discutem no trabalho os pressupostos de currículos CTS, buscando discutir como elaborar novos modelos curriculares para as Ciências da Natureza que possam preparar o aluno para a cidadania. No artigo se discute o que são currículos CTS, um histórico do movimento CTS e porque ele surgiu, os objetivos do ensino CTS e a seguir apresenta algumas visões de diferentes autores sobre o que seria e qual a importância da ciência, da tecnologia e da sociedade, dando maior ênfase a cada termo separadamente e inter-relacionados. Nesse momento o artigo discute um pouco a importância de se tratar a tecnologia no ensino de ciências e seus autores argumentam que a tecnologia é muito importante para a sociedade e conhecimento indispensável para exercer a cidadania. Os autores apresentam como definição para a tecnologia: "conhecimento que nos permite controlar e modificar o mundo" e a definição de Vargas (1994): “A tecnologia consiste em um conjunto de atividades humanas, associadas a sistemas de símbolos, instrumentos e máquinas, visando à construção de obras e à fabricação de produtos por meio de conhecimento sistematizado (SANTOS; MORTIMER, 2002, p. 8). Então é apresentado que a tecnologia está ligada ao conhecimento científico de forma indissociável, mas não pode ser reduzida somente a ele e por isso surge a confusão de acreditar que a tecnologia é ciência aplicada. Os autores argumentam a importância de o aluno compreender verdadeiramente a tecnologia e não apenas entendê-la como ciência aplicada, considerando que ela possui implicações econômicas e sociais. É necessário que o aluno aprenda sobre tecnologia não apenas para saber utilizar artefatos tecnológicos, mas compreender suas implicações e como ela afeta sua vida.

Resultados e Discussões 
- Alfabetização científico-tecnológica para quê? (2001), Décio Auler e Demétrio Delizoicov: o artigo aborda a questão da alfabetização científica e tecnológica (ACT), que possui amplos significados. No trabalho, a ACT é discutida com base em duas classificações: reducionista e ampliada. A perspectiva reducionista defende a neutralidade da ciência e da tecnologia, a superioridade do modelo de decisões tecnocráticas, perspectiva salvacionista da ciênciatecnologia e o determinismo tecnológico, chamados mitos sobre ciência e tecnologia. Já a perspectiva ampliada, defende as interações CTS e busca problematizar esses mitos.

- O conceito Cultura Tecnológica e um estudo no meio educacional (2007), Zulmira Medeiros e Paulo Cezar Santos Ventura: é apresentado o conceito de cultura, como um conjunto de comportamentos de uma sociedade específica que a diferencia e separa de outras. Hoje a tecnologia causa grandes mudanças na sociedade e a cultura dessas sociedades também vai passando por transformações. São necessárias novas formas de comportamento para acompanhar essas mudanças. Esse novo comportamento devido às mudanças causadas na sociedade pela tecnologia é chamado de cultura tecnológica. Os autores fazem uma discussão a respeito do significado de cultura e como ela influencia as atitudes das pessoas.

Experiências em Ensino de ciências: Neste periódico a tecnologia não foi abordada com mais ênfase em nenhum dos artigos encontrados. Dos artigos analisados, 52 deles apenas mencionam a questão da tecnologia, 9 abordam o ensino CTS e 8 artigos abordam a utilização de TICs. Entretanto, nenhum deles discutiu a questão da tecnologia, ficando de fora inclusive nos artigos que abordavam o tema CTS.

- Investigações em Ensino de ciências: Nesse periódico foram encontrados 32 trabalhos que mencionam a tecnologia. Desses trabalhos, apenas 2 artigos abordam com maior ênfase a questão da tecnologia. Os artigos em questão estão discutidos abaixo. Dos demais artigos, 22 apenas mencionam a questão da tecnologia, 6 artigos abordam a questão de CTS e 2 artigos abordam a questão de TICs.

- O Ensino de ciências nos anos iniciais do Ensino Fundamental sob a ótica CTS: uma proposta de trabalho diante dos artefatos tecnológicos que norteiam o cotidiano dos alunos (2013), Fabiane Fabri e Rosemari Monteiro Castilho Foggiatto Silveira: O artigo traz os resultados de uma proposta de ensino sobre artefatos tecnológicos aplicada aos alunos dos

Resultados e Discussões 
anos iniciais do ensino fundamental. As autoras abordam a importância de se ensinar ciência, tecnologia e a importância de se abordar o tema de artefatos tecnológicos no ensino fundamental. São discutidos os princípios e características de um ensino de ciências com enfoque CTS e a questão da ACT. O projeto foi desenvolvido com alunos do $4^{\circ}$ ano do ensino fundamental, séries iniciais, com idade entre 9 e 12 anos. Os alunos acreditam que a ciência e os cientistas trazem apenas benefícios à humanidade, fazendo apenas descobertas boas. Também é percebida a ideia de que tudo que os cientistas falam são verdades incontestáveis. A ideia de cientista é de uma pessoa maluca e de um gênio. Os alunos fizeram uma entrevista com um cientista, visando aproximá-los do trabalho de pesquisadores. Em relação à tecnologia, os alunos associaram o seu significado com artefatos tecnológicos, dizendo que tecnologia são computadores, televisões, rádios e outros. A visão de tecnologia dos alunos também está atrelada apenas aos benefícios da mesma, dizendo que ela serve para melhorar a vida do ser humano. Após esse questionário, foi desenvolvida e aplicada uma sequência didática abordando o tema artefatos tecnológicos. Foi abordado o tema lixo tecnológico, a importância do descarte adequado de produtos tecnológicos e a questão da reciclagem. Os alunos também estudaram um pouco sobre a história dos artefatos tecnológicos, como são construídos e os materiais presentes nos artefatos. Também foi abordada a questão da energia e formas de energia. Também ocorreu uma discussão sobre o consumismo e o consumo desenfreado de produtos tecnológicos. Aliada à discussão sobre o lixo tecnológico, foi realizada uma visita a uma cooperativa de recicláveis na cidade, onde os alunos conseguiram compreender melhor como ocorre o processo de reciclagem.

- Abordagem das relações ciência/tecnologia/sociedade nos conteúdos de funções orgânicas em livros didáticos de química do Ensino Médio (2009), Carmem Lúcia Costa Amaral, Eduardo da Silva Xavier e Maria de Lourdes Maciel: O artigo investigou como está sendo abordada a relação CTS nos livros didáticos de Química aprovados pelo PNLD. Os conteúdos escolhidos para análise foram funções orgânicas e a análise foi realizada com base no referencial teórico de Fracalanza e Megid-Neto (2006). Fracalanza e Megid-Neto (2006) apresentam indicadores para avaliar as relações CTS. O resultado da análise dos livros didáticos mostra que as obras buscam associar os conhecimentos científicos com fatos do cotidiano, mas isso ocorre de forma bastante superficial, não permitindo ao aluno compreender as implicações sociais da ciência e da tecnologia. É apresentado em todos os 
livros didáticos em questão que o conhecimento científico é a base para o conhecimento tecnológico. Nesse caso, embora os autores não tenham chamado dessa maneira, podemos perceber a ideia de tecnologia como ciência aplicada. O contrário disso não é percebido nos livros didáticos, não são percebidos exemplos em que a tecnologia é vista como capaz de auxiliar no desenvolvimento da ciência. Os benefícios relacionados à tecnologia também estão presentes em todas as coleções, sendo utilizados como uma forma de exemplificação da tecnologia na sociedade.

Química Nova na Escola: Esse periódico é o que contém mais artigos que mencionam a palavra tecnologia. Entretanto, apenas 3 artigos abordam realmente a questão tecnológica. Dos demais artigos, 144 apenas mencionam a palavra tecnologia, 15 abordam a questão CTS e 9 abordam a utilização de TICs.

- Questões Tecnológicas Permeando o Ensino de Química: O Caso dos Transgênicos (2008), Jacqueline Aparecida Takahashi, Polyana Fabrícia Fernandes Martins e Ana Luiza de Quadros: As autoras abordam a importância de o aluno compreender a questão tecnológica para compreender o mundo de uma forma mais crítica e poder se posicionar em relação às influências da tecnologia na sociedade. Os autores utilizam o tema transgênico como um exemplo de tecnologia que é importante que o aluno compreenda. Defendendo a importância da compreensão do tema transgênicos, foi aplicado um questionário a 30 alunos do $3^{\circ}$ ano do ensino médio e a 20 professores que lecionam no ensino médio. O questionário perguntava se os alunos sabiam o que é um alimento transgênico, se conhecem algum alimento desse tipo, se já consumiram, se continuariam consumindo ao saber que é transgênico e a finalidade desses produtos. As respostas mostram que a mídia é a principal fonte de informação de alunos e professores sobre o tema transgênicos. Muitos alunos e professores não conhecem alimentos transgênicos e os que conheciam citaram apenas a soja como exemplo. Apesar de não conhecer quais alimentos são transgênicos, a maioria dos alunos e professores já consumiram mais de um alimento desse tipo. O questionário mostra que apesar dos alunos e professores já terem ouvido falar sobre alimentos transgênicos, o entendimento sobre o tema é bastante limitado. Dessa forma, os autores acreditam que a escola deve preparar melhor os alunos para discussões sobre esse tema importante.

- Afinal, o que é Nanociência e Nanotecnologia? Uma Abordagem para o Ensino Médio (2009), Suzeley Leite Abreu Silva, Marcelo Machado Viana e Nelcy Della Santina Mohallem: 
$\mathrm{O}$ artigo aborda o significado de nanociência e nanotecnologia. Considerando a importância de se abordar o tema no ensino, o artigo propõe uma história para a abordagem do tema e quais conceitos devem ser desenvolvidos.

- O Lixo Eletroeletrônico: Uma Abordagem para o Ensino Fundamental e Médio (2010), Rafael da Silva Oliveira, Elisa Silva Gomes e Júlio Carlos Afonso: O lixo eletrônico é um grande problema da sociedade atual. Os autores discutem essa problemática, trazendo dados de como o lixo eletrônico tem afetado o meio ambiente. $\mathrm{O}$ artigo discute dezesseis palestras sobre lixo eletrônico ministradas a alunos do ensino fundamental, realizadas em feiras de ciências e semanas culturais. As palestras apresentavam a questão do lixo tecnológico, dados de produção, consumo e descarte, materiais tóxicos presentes no lixo tecnológico e consequências para o meio ambiente. As autoras acreditam que o tema foi de grande importância para sensibilização dos alunos e discutir a influência da tecnologia na sociedade.

Revista Brasileira de Ensino de Ciência e Tecnologia: Neste periódico foram encontrados 31 trabalhos sobre tecnologia. Desses trabalhos, 10 artigos apenas mencionam a palavra tecnologia, 11 abordam a temática CTS sem dar atenção à tecnologia e 6 abordam a utilização de TICs. Apenas 4 trabalhos abordam a questão tecnológica com maior destaque. Os trabalhos estão expostos a seguir.

- Concepções sobre o Conhecimento Tecnológico e a Estrutura Curricular dos Cursos Técnicos (2011), Saul Silva Caetano e Irlan von Linsingen: O trabalho inicia abordando a questão do ensino técnico, sua história e seus objetivos. A proposta do artigo é uma reflexão sobre as concepções de tecnologia e ciência na estruturação do currículo do ensino técnico. $\mathrm{O}$ autor também aborda que o conceito de tecnologia é polissêmico e apresenta que a definição de tecnologia utilizada no artigo é "uma ação social humana de criação de artefatos e procedimentos destinados a intervir na natureza, buscando a satisfação das necessidades do homem" (p. 38). O ensino técnico passou por uma série de alterações curriculares, cabendo aos professores dos cursos técnicos elaborar os currículos. Enquanto alguns cursos tiveram seus currículos divididos em disciplinas com repasse de conteúdos, outros foram estruturados a partir de projetos a serem desenvolvidos. Essas diferenças refletem as concepções dos professores que elaboraram seus currículos. Se a concepção do professor for de conhecimento como cumulativo e sem ruptura pode ser traduzida em uma concepção de currículo com

Resultados e Discussões 
disciplinas com conteúdos isolados. Os conteúdos são apresentados como prontos e acabados. Apesar dos professores possuírem uma visão de tecnologia como algo em constante mudança, ainda sim os conteúdos repassados aos alunos são apresentados como estáticos.

- Alfabetização científica e tecnológica nos anos iniciais a partir do tema lixo tecnológico (2012), Fabiane Fabri e Rosemari Monteiro Castilho Foggiatto Silveira: o artigo aborda um estudo desenvolvido com alunos do $4^{\circ}$ ano das séries iniciais do ensino fundamental sobre lixo tecnológico. O trabalho visa a uma alfabetização científica e tecnológica desses alunos. As autoras abordam a importância de se abordar a tecnologia, visto que elas estão impregnadas na sociedade, são influenciadas por ela e a influenciam. A ciência promove o avanço tecnológico, assim como a tecnologia promove o avanço científico. Porém, tanto a ciência quanto a tecnologia podem ter influências negativas na sociedade. É citada a questão do consumismo e como isso aumenta a quantidade de lixo tecnológico e a importância de se abordar essa questão com os alunos. Foram realizadas aulas para abordar a questão do lixo tecnológico com os alunos e a importância da reciclagem. A abordagem foi através de miniaulas, produções escritas, visita a cooperativa de reciclagem, entre outros. Segundo as autoras, ao final do estudo os alunos conseguiram fazer algumas reflexões sobre as questões sociais do desenvolvimento tecnológico.

- Mediação da trilogia "Fundação" como possível parâmetro para análises do determinismo tecnológico no Ensino de Ciências (2014), Awdry Feisser Miquelin, Nestor Cortez Saavedra Filho e Sam Adam Hoffmann Conceição: os autores buscam fazer uma discussão entre os artefatos tecnológicos e a tecnologia presentes na sociedade com obras de ficção científica. Neste caso, a obra em questão é a trilogia Fundação de Isaac Asimov. Essa proposta teórica é feita para que os professores possam utilizar essa discussão com os alunos. A partir dessa obra é possível fazer algumas reflexões sobre as questões sociais que envolvem o uso da tecnologia. O determinismo tecnológico também é algo que pode ser discutido a partir da obra, fazendo um paralelo desses livros de ficção científica com a sociedade atual. Os autores acreditam que obras de ficção científica podem ter um importante papel nas discussões sobre as implicações sociais e econômicas da tecnologia, estabelecendo relações com os problemas tecnológicos atuais que a sociedade enfrenta.

Resultados e Discussões 
- Uma proposta didática com abordagem CTS para o estudo dos gases e a cinética química utilizando a temática da qualidade do ar interior (2015), Silvaney de Oliveira, Orliney Maciel Guimarães, Leonir Lorenzetti: O artigo aborda uma sequência de aulas sobre a qualidade do ar interior, relacionando com o estudo dos gases e cinética química. No artigo ocorre a descrição da sequência de aulas, discutindo como ocorreu a sua aplicação. Os autores acreditam que a sequência pode ser uma importante forma de abordar as questões CTS em sala de aula. Na sequência didática proposta os autores buscam uma alfabetização científica e tecnologia dos alunos. Na questão da alfabetização tecnológica, os autores propõem debater as implicações da tecnologia na sociedade, discutir a natureza da tecnologia e as relações entre tecnologia, ciência e sociedade. Essa discussão ocorreu por meio da leitura do texto "A filosofia da tecnologia" (CUPANI, 2011) e de discussões em sala de aula, buscando articular com artefatos tecnológicos.

Revista Brasileira de Ensino de Física: Dos trabalhos desse periódico, 2 deles abordam o tema tecnologia. Os demais trabalhos, 36 artigos apenas mencionam a palavra tecnologia, 6 abordam a questão CTS e 3 trabalhos abordam a questão de TICs.

- A concepção dos alunos sobre a física do Ensino Médio: um estudo exploratório (2007), Elio C. Ricardo e Janaína C.A. Freire: é apresentado um estudo sobre as concepções dos alunos do ensino médio sobre o ensino de física. O estudo foi realizado com alunos do ensino médio de escolas públicas por meio da aplicação de questionários. Os resultados mostram que os alunos associam a física com a matemática, como se a disciplina fosse apenas a realização de cálculos. Uma das questões do questionário buscava averiguar se os alunos tiveram um ensino de física que os permitisse estabelecer relações entre a física e a tecnologia. Os alunos tiveram bastante dificuldade para associar a física com a tecnologia, isso porque não tiveram um ensino que lhes permitisse entender a tecnologia. A concepção de tecnologia como ciência aplicada também apareceu nos questionários. Os alunos costumam associar a importância de se aprender física com o cotidiano e a utilização de tecnologias, entretanto a física escolar pouco auxilia o aluno a compreender o cotidiano e as tecnologias. Nesse caso, a tecnologia geralmente é utilizada apenas como uma ilustração dos conteúdos a serem aprendidos e em raríssimas vezes os alunos recebem uma formação explícita em tecnologia.

Resultados e Discussões 
- A tecnologia como referência dos saberes escolares: perspectivas teóricas e concepções dos professores (2007), Elio Carlos Ricardo, José Francisco Custódio e Mikael Frank Rezende Junior: O trabalho aborda as concepções dos professores em relação ao significado da tecnologia e seu ensino. Os professores entrevistados são das disciplinas de física, química, biologia e matemática. A tecnologia tem sido apontada como necessária, sendo relacionada à contextualização do conhecimento. Nesse contexto, é necessário discutir o sentido atribuído à tecnologia. Os autores discutem que a tecnologia deve ser abordada como um conteúdo escolar e não apenas como ilustração e sobre a possiblidade de tornar a tecnologia um saber de referência. Uma parcela dos professores entrevistados reduz a tecnologia à utilização da informática. Nesse caso a tecnologia não é vista como um objeto de ensino e sim como um instrumento para atrair a curiosidade dos alunos. Outra visão compartilhada pelos professores é da tecnologia como uma aplicação da ciência, onde a ciência sempre precede a tecnologia. A tecnologia é vista como uma forma de motivação dos alunos para aprender o conteúdo científico e são ensinados apenas os produtos da tecnologia e não o processo de investigação.

Revista Brasileira de Pesquisa em Educação em Ciências: Dos trabalhos investigados dessa revista, apenas 16 mencionam a questão da tecnologia, 18 abordam a questão CTS e 7 abordam a utilização de TICs. Apenas um trabalho abordou a questão da tecnologia com mais ênfase.

- Robôs e androides: a abordagem de questões sociopolíticas de ciência e tecnologia em sala de aula (2011), Luís Paulo Piassi: o autor analisa a questão de obras de ficção científica e a tecnologia apresentada nessas obras. O trabalho busca verificar se a leitura desses textos de ficção científica pode levar o aluno às reflexões sobre questões epistemológicas e sociopolíticas de ciência e tecnologia. Foi ministrada uma disciplina aos alunos de cursos não relacionados à área científica. Essa disciplina apresentava tópicos de ficção científica, trechos de filmes de ficção científica e leitura de contos de ficção científica. Posteriormente, ocorria uma discussão sobre os materiais e os alunos apresentavam comentários escritos sobre os assuntos. O objetivo do trabalho foi analisar esses comentários e as interpretações sobre as obras de ficção científica. Os comentários mostram discussões dos alunos a respeito do papel da tecnologia na vida humana.

Resultados e Discussões 
Com base no exposto sobre os artigos que abordam o tema da tecnologia é possível observar que, apesar de haver vários artigos abordando o tema CTS e educação científica e tecnológica, são poucos os trabalhos que abordam a questão da tecnologia de maneira mais clara e com maior ênfase. Nos demais trabalhos, a tendência é reduzir a tecnologia como algo de caráter secundário. Fala-se apenas em ensinar ciência e a tecnologia fica completamente esquecida, ou acredita-se que ambas são a mesma coisa.

Mesmo nos artigos em que a tecnologia é abordada de forma mais clara, muitos deles ainda não trazem uma discussão maior sobre o conceito de tecnologia e finalidades do seu ensino. Dos artigos selecionados 15 deles apresentam propostas para trabalhar a tecnologia na educação básica, 9 abordam concepções sobre tecnologia, 3 trazem discussões teóricas sobre a tecnologia, 2 abordam a tecnologia nos livros didáticos e 1 aborda um curso de formação em tecnologia para engenheiros.

Dos 15 artigos que apresentam propostas para trabalhar a tecnologia na educação básica, 8 propõem a abordagem da tecnologia em sala de aula utilizando como tema os artefatos tecnológicos. Desses trabalhos, 3 que propõem a utilização de artefatos tecnológicos, como tema da proposta de ensino, abordam a construção de artefatos tecnológicos em sala de aula para que os alunos compreendam o seu funcionamento. Os artefatos tecnológicos específicos sugeridos para serem construídos são: aeromodelo, transmissor de voz e coletor solar. Os outros 5 trabalhos que propõem os artefatos tecnológicos como tema não utilizam um artefato tecnológico específico na proposta, apenas falam de artefatos tecnológicos de uma forma geral e da importância dos alunos compreenderem o seu funcionamento, sem especificar nenhum. Dos demais artigos que trazem propostas para abordar a tecnologia em sala de aula, 3 fazem propostas de abordar a tecnologia a partir de obras de ficção científica, 1 através de uma visita à um museu de ciências, 1 sugere trabalhar com alimentos transgênicos, 1 propõe discutir a questão dos riscos tecnológicos e 1 sugere abordar a definição da tecnologia e a filosofia da tecnologia.

Sobre os 9 artigos que abordam as concepções de tecnologia da sociedade, 4 artigos discutem as concepções de tecnologia dos professores, 2 artigos discutem as concepções de alunos do ensino médio, 1 artigo discute concepções de tecnologia de graduandos, 1 artigo discute as concepções de pessoas que trabalham com tecnologia, como engenheiros e tecnólogos e 1 artigo discute as concepções da sociedade em geral sobre tecnologia. Os 
artigos mostram que, em geral, as pessoas, tanto alunos como professores, não compreendem o significado de tecnologia. As concepções mais comuns apontadas pelos artigos são da tecnologia como ciência aplicada, tecnologia como algo benéfico capaz de salvar a humanidade e tecnologia como neutra. Isso mostra que além de desconhecer o significado da tecnologia, a sociedade não compreende as implicações sociais da tecnologia. Essas concepções de tecnologia retiradas dos artigos analisados serão posteriormente utilizadas para a análise de livros didáticos, visando a compreender se os livros didáticos estão contribuindo para a manutenção dessas concepções.

Também foram analisados 2 trabalhos que faziam análise da tecnologia nos livros didáticos (AMARAL, XAVIER, MACIEL, 2009; MACEDO, SILVA, 2010). Um deles analisava como ocorria a contextualização e como a tecnologia era apresentada em livros didáticos de física. A conclusão do trabalho é que a tecnologia é apresentada como neutra e sem influências sociais. Em outro trabalho, buscou-se analisar como a tecnologia é apresentada em livros didáticos de química no conteúdo de química orgânica. Os resultados mostram que os benefícios da tecnologia são exaltados, ela é vista como dependente do desenvolvimento científico e é apresentada de forma bastante superficial. Esses dois trabalhos revelam como a tecnologia foi apresentada em livros didáticos mais antigos, anteriores a 2010. Eles também oferecem um panorama do que se poderá encontrar na análise de livros didáticos proposta neste trabalho.

Em relação aos 3 artigos que trazem discussões teóricas sobre tecnologia, 1 deles discute a questão da cultura tecnológica, 1 faz uma discussão sobre um ensino CTS, e 1 deles discute sobre nanociência e nanotecnologia. Os artigos que apresentam discussões teóricas apresentados não se aprofundam tanto em discutir a questão da tecnologia.

Resultados e Discussões 


\subsection{A tecnologia nos documentos oficiais de Ensino de Ciências}

O ensino de Química é permeado por documentos oficiais que direcionam o professor sobre o que ensinar em sala de aula. Existem diversos documentos que podem direcionar o trabalho do professor, tanto documentos estaduais como nacionais. Nosso foco será analisar documentos nacionais. Os documentos analisados foram: Parâmetros Curriculares Nacionais para o Ensino Médio - PCNEM (BRASIL, 1999), PCN+ Ensino Médio: orientações educacionais complementares aos Parâmetros Curriculares Nacionais (BRASIL, 2002), Orientações Curriculares para o Ensino Médio (BRASIL, 2006) e Diretrizes Curriculares Nacionais da Educação Básica - DCNEB (BRASIL, 2013). Visto a importância desses documentos, buscou-se compreender o que eles dizem a respeito do ensino de tecnologia.

$\mathrm{Na}$ análise dos documentos oficiais, percebe-se que o tema tecnologia está presente, impondo que ele deve ser abordado em sala de aula. Porém, como esta abordagem deve ser realizada e como está sendo realizado atualmente nas escolas é algo que não fica muito claro e necessita de reflexão e discussão.

Na análise dos PCNEM (BRASIL, 1999), percebe-se a referência ao termo tecnologia em todo o documento. Apesar de enfatizarem tanto o termo em vários momentos, a expressão tecnologia refere-se tanto à "tecnologia educacional" quanto "educação tecnológica". Quando se refere à tecnologia educacional, o documento está fazendo menção à utilização de artefatos tecnológicos em sala de aula, como computadores, televisão, etc. A educação tecnológica seria o ensino sobre tecnologia, na qual a tecnologia seria algo a ser ensinado ao aluno e não uma ferramenta de ensino.

Os PCNEM ressaltam que a tecnologia é muito importante para a sociedade atual e seus ensinamentos devem estar presentes nas escolas. Durante todo o documento há uma defesa constante do ensino de tecnologia nas escolas, abordando a sua relevância para uma melhor compreensão do cotidiano e dos processos que envolvem a vida contemporânea. $\mathrm{O}$ ensino de tecnologia é defendido no documento não apenas como obrigatório para as Ciências da Natureza, mas também para todas as áreas de conhecimento, como podemos ver no seguinte trecho:

A presença das tecnologias em cada uma das áreas merece um comentário mais longo. A opção por integrar os campos ou atividades de aplicação, isto é, os processos tecnológicos próprios de cada área de conhecimento, resulta da 
importância que ela adquire na educação geral - e não mais apenas na profissional -, em especial no nível do Ensino Médio. Neste, a tecnologia é o tema por excelência que permite contextualizar os conhecimentos de todas as áreas e disciplinas no mundo do trabalho (BRASIL, 1999, p. 93).

Os PCNEM propõem um currículo dividido em três áreas (Linguagens e Códigos, Ciências Humanas, e Ciências da Natureza e da Matemática), abrangendo disciplinas entendidas como conectadas e a tecnologia (ou as tecnologias) seria o integrador entre essas áreas. A tecnologia é vista no documento como uma forma de aplicar os conhecimentos da Educação Básica: "remete diretamente às atividades relacionadas à aplicação dos conhecimentos e habilidades constituídas ao longo da Educação Básica, dando expressão concreta à preparação básica para o trabalho prevista na LDB” (BRASIL, 1999, p. 95).

Apesar da ênfase, no documento não está claro o que se entende por ensino de tecnologia e como esse ensino deveria ocorrer. Também se percebe a ideia de que o desenvolvimento tecnológico e a presença de artefatos tecnológicos no nosso cotidiano é a justificativa para aprender sobre ciência e tecnologia. A tecnologia, nesse caso, é vista como uma forma de contextualização dos conteúdos científicos e de aproximar a ciência das pessoas.

Assim, nos PCNEM é entendido como um dos objetivos do ensino de ciências a compreensão do significado de ciência e da tecnologia. Entretanto, o significado da tecnologia é bastante complexo e sua compreensão não se limita a definições prontas, mas a um estudo mais detalhado da tecnologia em sala de aula. O documento também apresenta algumas competências e habilidades que os alunos devem desenvolver durante sua trajetória escolar, em Ciências da Natureza. Algumas dessas competências e habilidades estão citadas a seguir:

[...] Aplicar as tecnologias associadas às Ciências Naturais na escola, no trabalho e em outros contextos relevantes para sua vida; [...] Compreender e utilizar a ciência, como elemento de interpretação e intervenção, e a tecnologia como conhecimento sistemático de sentido prático; [...] Reconhecer o sentido histórico da ciência e da tecnologia, percebendo seu papel na vida humana em diferentes épocas e na capacidade humana de transformar o meio [...] Entender o impacto das tecnologias associadas às Ciências Naturais, na sua vida pessoal, nos processos de produção, no desenvolvimento do conhecimento e na vida social." (BRASIL, 1999, p. 13).

Nestes trechos, pode-se ressaltar a compreensão dos PCNEM em relação ao papel da tecnologia no ensino. Entretanto, o termo tecnologia ainda aparece no documento sem muito direcionamento para os professores, ou seja, torna-se difícil para os professores cumprirem as recomendações, de modo a desenvolverem essas competências nos alunos. Nos PCNEM, a 
tecnologia aparece em cada uma das áreas de conhecimentos. $\mathrm{Na}$ área de Ciências da Natureza e Matemática sugere-se que a tecnologia forneça uma visão relacionada aos processos tecnológicos industriais, produtos e artefatos tecnológicos. O direcionamento é para que esses conhecimentos não sejam puramente técnicos, mas incorporar informações e conhecimentos úteis para o cotidiano e para a cidadania (BRASIL, 1999).

O ensino de tecnologia não implica necessariamente em um ensino mais crítico. Primeiramente, é necessário discutir a forma como o ensino de tecnologia está sendo inserido no contexto educacional e que tipo de tecnologia está sendo apresentada aos alunos. O conhecimento tecnológico, assim como o científico não é neutro, mas está carregado de interesses sociais, políticos e econômicos, que devem ser abrangidos durante o seu ensino.

Além dos PCNEM, o Ministério da Educação e especialistas da área construíram os PCN+ Ensino Médio: orientações educacionais complementares aos Parâmetros Curriculares Nacionais (BRASIL, 2002). Esse documento apresenta uma série de orientações a serem consideradas em relação ao ensino. Essas orientações servem como um complemento para os PCN. Na análise desse documento percebe-se que ele reforça ainda mais a importância de se trabalhar a tecnologia em sala de aula, inclusive nas competências e habilidades.

Outro documento norteador do ensino são as Orientações Curriculares para o Ensino Médio (BRASIL, 2006). Esse documento também coloca a tecnologia em um ponto de destaque no ensino e aponta para a importância da compreensão da tecnologia para o desenvolvimento da cidadania, como se pode perceber neste trecho que diz que é importante que os alunos:

[...] compreendam o mundo social em que estão inseridos e desenvolvam a capacidade de tomada de decisão com maior responsabilidade, na qualidade de cidadãos, sobre questões relativas à Química e à Tecnologia, e desenvolvam também atitudes e valores comprometidos com a cidadania planetária em busca da preservação ambiental e da diminuição das desigualdades econômicas, sociais, culturais e étnicas (BRASIL, 2006).

Em outro documento, DCNEB, a palavra tecnologia é citada 209 vezes durante todo o documento, o que revela a importância dada à tecnologia por esse documento. $\mathrm{O}$ documento defende bastante a utilização da tecnologia em sala de aula, as chamadas Tecnologias da Informação e Comunicação que, como exposto acima seria o ensino utilizando artefatos tecnológicos. Além disso, o documento também defende que os alunos devem compreender sobre a tecnologia e sobre a utilização de artefatos tecnológicos, em todos os níveis de ensino, 
desde o início da Educação Básica. No trecho abaixo, pode-se perceber que o ensino de tecnologia é algo a ser defendido na Educação Básica:

\begin{abstract}
Isto porque o conhecimento científico, nos tempos atuais, exige da escola o exercício da compreensão, valorização da ciência e da tecnologia desde a infância e ao longo de toda a vida, em busca da ampliação do domínio do conhecimento científico: uma das condições para o exercício da cidadania. O conhecimento científico e as novas tecnologias constituem-se, cada vez mais, condição para que a pessoa saiba se posicionar frente a processos e inovações que a afetam. Não se pode, pois, ignorar que se vive: o avanço do uso da energia nuclear; da nanotecnologia; a conquista da produção de alimentos geneticamente modificados; a clonagem biológica. Nesse contexto, tanto o docente quanto o estudante e o gestor requerem uma escola em que a cultura, a arte, a ciência e a tecnologia estejam presentes no cotidiano escolar, desde o início da Educação Básica (BRASIL, 2013, p. 26).
\end{abstract}

Ao abordar o ensino médio, é defendido neste documento que o ensino deve se basear em quatro dimensões: trabalho, ciência, tecnologia e cultura. Portanto, a tecnologia deveria ser um dos fundamentos básicos para a formação humana. Apesar de todos os demais documentos também abordarem a inserção da tecnologia no ensino médio, apenas as DCNEB trazem uma definição para tecnologia:

A extensão das capacidades humanas, mediante a apropriação de conhecimentos
como força produtiva, sintetiza o conceito de tecnologia aqui expresso. Pode ser
conceituada como transformação da ciência em força produtiva ou mediação do
conhecimento científico e a produção, marcada desde sua origem pelas relações
sociais que a levaram a ser produzida. O desenvolvimento da tecnologia visa à
satisfação de necessidades que a humanidade se coloca, o que nos leva a perceber
que a tecnologia é uma extensão das capacidades humanas. A partir do nascimento
da ciência moderna, pode-se definir a tecnologia, então, como mediação entre
conhecimento científico (apreensão e desvelamento do real) e produção (intervenção
no real) (BRASIL, 2013, p.26).

Nesta definição pode-se perceber que o documento associa a tecnologia ao conhecimento científico. A tecnologia seria considerada uma "transformação da ciência" e é ressaltada que a tecnologia envolve relações sociais. Apesar de possuir uma definição para tecnologia, a forma como deve ocorrer uma educação tecnológica ou um ensino de tecnologia ainda fica bastante vago.

A Base Nacional Comum Curricular - BNCC (BRASIL, 2016), apesar de ainda não ter sido aprovada, será um documento de bastante importância para a educação, pois estabelecerá como deverá ocorrer o ensino em todo o país. Esse documento consta no site do Ministério da Educação como uma versão preliminar em que serão feitas modificações até ser aprovada. Aqui analisou-se a segunda versão da BNCC corrigida, elaborada em abril de 2016. 
O termo tecnologia também é citado diversas vezes na BNCC, um total de 156 vezes. A base também discute muito a importância de se trabalhar com artefatos tecnológicos no ensino, como computador, televisão, etc, as chamadas TICs- Tecnologias da Informação e Comunicação.

Na parte de Ciências da Natureza, a base também aborda que o ensino deve ocorrer com base nas relações CTS e defende que o aluno deve compreender o desenvolvimento histórico da ciência e da tecnologia. A BNCC também defende, assim como as DCNEB, que o ensino deve se pautar em quatro dimensões: trabalho, ciência, tecnologia e cultura. $\mathrm{O}$ documento reforça bastante o que as Diretrizes propõem sobre a tecnologia ser uma das dimensões do ensino e também reforça aquilo que muitos autores da área já defendem há muito tempo, um ensino em uma perspectiva CTS.

Dessa forma, pode-se perceber que todos os documentos oficiais apontam para a importância do ensino de tecnologia nas escolas. Porém não há uma posição clara do que os documentos entendem por tecnologia e por educação tecnológica. Apesar de se compreender que o tema tecnologia é bastante polêmico, não há definições muito claras e não há um consenso sobre o seu significado, sem um "norte" apontado pelos documentos oficiais, tornase muito difícil que o professor sozinho consiga fazer suas próprias conclusões e tomar suas atitudes. Dessa forma, as propostas educacionais tendem a não sair do papel, considerando que os professores que deveriam colocá-las em prática não possuem orientação suficiente para tal.

Resultados e Discussões 


\subsection{A tecnologia no GLD e editais do PNLD}

Para auxiliar o professor na escolha do livro, foi criado o Guia de Livros Didáticos (GLD). Nele são descritos os livros aprovados pelo MEC. Os livros didáticos aprovados estarão descritos em uma resenha no GLD e poderão ser escolhidos pelos professores das escolas da Educação Básica para a utilização em sala de aula. O GLD é um documento bastante importante para a escolha do professor, pois as resenhas apresentam as potencialidades e as fragilidades dos livros avaliados. Na avaliação do PNLD de 2015, foram inscritas 13 coleções de livros didáticos, de diferentes autorias e diferentes editoras. Dessas coleções 4 foram aprovadas e 9 foram excluídas.

O GLD 2015 aponta como questões norteadoras do ensino de química a experimentação, a história da ciência e a contextualização dos conteúdos. A experimentação é apontada como de fundamental importância para a compreensão dos fenômenos químicos. O Guia também aponta a importância da experimentação investigativa e aborda que a experimentação como mera verificação de conceitos não é o ideal para promover uma aprendizagem com significado para os estudantes. Outra questão apontada no GLD é a importância da História da Ciência para a aprendizagem em Química. É importante apresentar a ciência como fruto da atividade humana na sociedade, demonstrando que a ciência não é resultado de alguns gênios brilhantes, mas sim construída ao longo do tempo e do trabalho coletivo. Segundo o GLD 2015:

\footnotetext{
Os conceitos científicos não são produtos da imaginação brilhante de gênios iluminados, que isoladamente teriam poder de mudar os rumos da ciência. Ao contrário, todo conhecimento científico é produzido por grupos de pesquisadores localizados em diferentes tempos históricos, em diferentes contextos socioeconômicos, em diferentes cenários políticos (BRASIL, 2014, p. 9).
}

O Guia também discute a importância da História da Ciência para apresentar o processo de construção do conhecimento científico e como os conceitos e descobertas da ciência estão intimamente ligados a aspectos sociais, econômicos, políticos, religiosos e culturais de uma época específica, humanizando, assim, a ciência. A terceira questão apontada pelo Guia como importante para o ensino de química é a contextualização dos conteúdos. O GLD aponta a contextualização como uma forma de relacionar os conteúdos escolares com o 
cotidiano do aluno e com a sociedade, considerando assim a formação do aluno para a cidadania.

O GLD também discute a importância da interdisciplinaridade e da produção de livros digitais. Ele aponta o livro didático como uma importante ferramenta para contribuir com a interdisciplinaridade na escola, auxiliando a estabelecer vínculos com as disciplinas. O GLD traz à tona a importância de discussões de questões de relevância social, utilizando articulações entre conhecimentos de várias disciplinas e campos do conhecimento. Outra questão relevante é a utilização de ferramentas digitais no aprendizado, como internet, aplicativos, redes sociais, vídeos, simulações, jogos, etc. Essas ferramentas podem estimular o aluno, auxiliar na aprendizagem e na compreensão dos modelos científicos e potencializar a aprendizagem do conteúdo. Essas são algumas sugestões do Guia para serem inseridas no ensino de química. O GLD apresenta a disciplina de química, dizendo que ela:

[...] ocupa um lugar importante na área de Ciências da Natureza, representando um campo científico que contribui de forma decisiva para o exercício da cidadania na sociedade contemporânea, cujos modos de vida são tão marcados pela tecnologia (BRASIL, 2014, p. 7).

Neste trecho podemos perceber uma relação explícita entre o ensino de química e a tecnologia. Na nossa sociedade atual, a tecnologia está muito presente na vida das pessoas, tornando-se impossível que a escola feche os olhos para isso. Portanto, percebe-se que uma educação tecnológica também é necessária para a formação de cidadãos mais atuantes na sociedade. Na citação acima percebe-se novamente que a presença da tecnologia na sociedade é usada como uma justificativa para aprender sobre ciência, neste caso específico a química. A tecnologia e a ciência também estão sendo associadas ao exercício da cidadania.

Na resenha dos livros didáticos aprovados, em dois deles consta uma referência direta à tecnologia. Apesar de em outras coleções não constar referência direta à tecnologia, como essa referência está nos documentos oficiais e nas pesquisas da área, serão analisadas as quatro coleções para responder à questão de pesquisa.

O Guia também ressalta a importância das relações CTS nos livros didáticos:

O tratamento das relações entre ciência, tecnologia e sociedade, no âmbito do ensino de Química, mostra-se como possibilidade bastante promissora para a aprendizagem no ensino médio, pois possibilita compreender a forma como a Química produz artefatos tecnológicos que garantem a existência do trabalhador e desenvolver a consciência sobre a relação entre conhecimento científico e questões sociais, envolvendo cidadania e consumo (BRASIL, 2014, p.10). 
Neste ponto, percebe-se uma orientação clara do Guia de que em sala de aula e no livro didático devem ser trabalhadas as relações CTS. Mas como o livro didático está seguindo essa recomendação do Guia? Os livros didáticos conseguem abordar essas relações claramente? Esses itens necessitaram de aprofundamento nesta pesquisa.

Dessa forma, o GLD apresenta várias referências sobre a importância da tecnologia no cotidiano das pessoas, devendo o ensino de química e, consequentemente, o livro didático darem atenção a esse tipo de conhecimento. Porém, como os livros estão abordando a tecnologia e as relações CTS? Portanto, nessa pesquisa será realizada a análise desses livros, visando a observar as concepções dos mesmos sobre tecnologia.

Antes das editoras enviarem os livros didáticos para avaliação, o Ministério da Educação faz a publicação de um edital contendo algumas orientações para as editoras de livros didáticos adequarem seus livros. A partir desse edital, as editoras escrevem seus livros para serem inscritos no PNLD. O edital é uma convocação do MEC para as editoras fazerem a inscrição de suas obras para avaliação no PNLD. O edital contém os prazos para as editoras inscreverem seus livros; algumas regras que as editoras devem seguir, como a quantidade de volumes e número de páginas; das documentações exigidas; se deve conter manual do professor, livros digitais; como é realizado o processo de triagem e a avaliação pedagógica; entre outros fatores para direcionar as editoras para a adequação dos livros didáticos. Todos esses fatores expressos no edital buscam deixar claro como é realizada a avaliação das obras, para que o processo de avaliação dos livros ocorra com critérios claros e pré-estabelecidos.

No edital de 2013 aparecem os critérios de avaliação que os livros passaram para serem aprovados e algumas orientações a respeito. Os livros aprovados fizeram parte do PNLD 2015. Na análise do edital do PNLD 2015, publicado no site do Ministério da Educação em 2013, já se percebe também algumas referências sobre a relação da tecnologia dentro do ensino de química. Segundo o edital:

[...] Porém, na medida em que a sociedade contemporânea é marcada, cada vez mais, por dinâmicas sociais definidas a partir das suas relações com a Ciência e com a Tecnologia, essa área curricular, no contexto escolar, vem assumindo papel específico na formação de nossos jovens, tornando-os aptos para o pleno exercício da cidadania, qual seja, o de garantir a sua adequada alfabetização científicotecnológica (BRASIL, 2013, p. 59).

Também é abordada no edital a importância de que os livros trabalhem em uma perspectiva CTS: 
Por isso, a utilização de discussões sobre as relações entre Ciência, Tecnologia e Sociedade, como elemento organizador das atividades de ensino de Biologia, de Física e de Química, constitui-se em importante ferramenta para a compreensão dos problemas contemporâneos e capacitação para tomada de decisões fundamentadas em argumentações consistentemente construídas, favorecendo, portanto, a possibilidade de uma melhor atuação dos nossos jovens na realidade social (BRASIL, 2013, p. 60).

O edital ainda aborda a questão da tecnologia, mostrando a importância dela no cotidiano dos alunos e que é de suma importância que eles aprendam o funcionamento de artefatos tecnológicos:

A abordagem do conhecimento científico, seja ele em Biologia, em Física ou em Química, com a priorização de uma visão integradora interdisciplinar, traz à tona reflexões importantes sobre as relações humanas nas dinâmicas do mundo do trabalho e do mundo da vida, visto que a contemporaneidade está marcada pela apropriação social e cultural da tecnologia como mediadora de processos de produção e de consumo. Assim, em cada eixo integrador, expressam-se diferentes aspectos da formação dos jovens no ensino médio, a saber: no trabalho, a possibilidade da qualificação e da habilitação profissional; na ciência, a iniciação científica, com a compreensão de fenômenos e processos naturais; na tecnologia, a iniciação tecnológica, com a compreensão dos funcionamentos e das aplicações dos artefatos tecnológicos na vida cotidiana; e, na cultura, a ampliação do repertório de práticas, princípios e conhecimentos (BRASIL, 2003, p. 60 e 61).

O edital aborda os critérios específicos de avaliação dos livros didáticos da disciplina de Química. Entre os critérios de avaliação estão:

[...] aborda a dimensão ambiental dos problemas contemporâneos, levando em conta não somente situações e conceitos que envolvem as transformações da matéria e os artefatos tecnológicos em si, mas também os processos humanos subjacentes aos modos de produção do mundo do trabalho (BRASIL, 2003, p. 65).

Portanto, todas as coleções deveriam apresentar uma discussão da relação entre tecnologia e questão ambiental. Este deveria ser um critério de eliminação para a avaliação das coleções de livros didáticos. Destaca-se para a importância das coleções abordarem a dimensão ambiental de forma relacionada à tecnologia. 


\subsection{A tecnologia nos Livros Didáticos}

As coleções de livros foram nomeadas do número 1 ao número 4. Cada coleção é caracterizada pela letra $\mathrm{C}$ e o número correspondente, sendo de 1 a 4 . Os livros são caracterizados pela letra L e o número do volume correspondente, sendo de 1 a 3 , o volume está relacionado com o ano do ensino médio a que é proposto. Assim, o símbolo C2-L1, por exemplo, indicaria a coleção 2 , livro volume 1 (primeiro ano do ensino médio), após é seguido pela indicação da página em que se encontra tal trecho a ser analisado. Os trechos retirados do livro para análise serão identificados por um número entre parênteses colocado na frente do trecho, estão em letra de menor tamanho, na forma de citação ou em tabelas.

Serão apresentados alguns casos encontrados de cada categoria, podendo um caso se encaixar também em mais de uma categoria. Quando isso ocorrer, a citação será repetida novamente em cada uma das categorias em que o caso se encaixa.

As coleções analisadas trazem de forma explícita na apresentação dos livros que irão abordar o tema tecnologia ou o tema CTS, como podemos ver na tabela 2 trechos retirados das apresentações das coleções. Os livros estão, logo na apresentação, comprometendo-se a realizar um ensino numa perspectiva CTS ou abordar a dimensão tecnológica. A apresentação é utilizada como uma forma de prometer ao aluno que ele irá aprender sobre tecnologia e isso o ajudará a exercer melhor sua cidadania.

A coleção 2 traz três apresentações diferentes, uma para cada livro do ensino médio. A coleção 2 se refere à tecnologia ou ao ensino CTS nas apresentações dos livros da forma apresentada na tabela 2.

Resultados e Discussões 
Tabela 2. Trechos retirados da apresentação dos livros didáticos da coleção 2 que abordam tecnologia.

(1) Com o propósito de formar um cidadão crítico, nos três volumes da coleção trataremos das relações entre a Química, as suas tecnologias, a sociedade e o ambiente. (C2, L1, p.3)

(2) Em nossa abordagem temática, daremos um enfoque à Química ambiental por meio de temas que demonstram os impactos da tecnologia química na sociedade e que possibilitam desenvolver ações que conciliem desenvolvimento tecnológico, qualidade de vida, preservação ambiental e justiça social. (C2, L1, p.3)

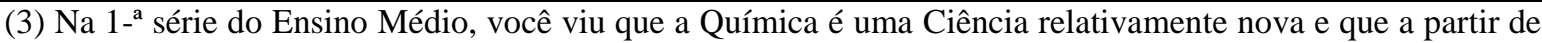
conhecimentos de outros campos científicos, como o da Física e Biologia, ela tem contribuído para o desenvolvimento de tecnologias que estão propiciando uma melhor qualidade de vida. (C2, L2, p. 3)

(4) Vamos ver neste livro como o conhecimento químico nos auxilia a compreender o mundo físico que nos rodeia e como a Química tem contribuído para o desenvolvimento de nossa sociedade. Você tem aprendido que a Química e as suas tecnologias têm provocado uma grande revolução em nosso modo de vida, mas que essa revolução, todavia, tem acarretado inevitavelmente mudanças drásticas no meio ambiente, ocasionando sérias consequências à vida no planeta. (C2, L2, p. 3)

(5) Assim é que temos tratado em todos os volumes desta coleção as relações entre a Química, as suas tecnologias, a sociedade e o ambiente. (C2, L2, p. 3)

(6) A metodologia adotada pelos autores desta obra, com larga experiência no Ensino de Química, tem como propósito capacitá-lo para resolver questões reflexivas que têm sido apresentadas no novo contexto. É por isso que em todos os volumes desta coleção tratamos das relações entre a Química, as suas tecnologias, a sociedade e o ambiente. Essa abordagem com textos sobre questões sociais propiciam o desenvolvimento de seu pensamento para o entendimento dos grandes problemas da atualidade que vai qualificá-lo para enfrentar os desafios do mercado de trabalho com uma visão mais crítica. A atualização de temas permitirá uma visão mais aguçada para enfrentar os exames que você encontrará pela frente. (C2, L3, p. 3)

(7) Esperamos que a conclusão de seu aprendizado em Química seja muito prazeroso com essa nova abordagem e que ele tenha continuidade com a sua busca incessante pelo acesso à informação que lhe torne um cidadão consciente e participante dos desafios da sociedade tecnológica atual. (C2, L3, p. 3)

A tabela mostra que na apresentação dos três livros da coleção 2 aparece mais de uma referência direta a tecnologia. Todos os livros da coleção 2 estão prometendo ao aluno que irão abordar a questão da tecnologia. Na citação 1, o livro manifesta que o objetivo é a formação de um cidadão crítico e, para isso, será utilizado um enfoque de ciência, tecnologia, sociedade e ambiente (CTSA). Durante o conteúdo dos livros dessa coleção, também percebemos essa preocupação em expor que o livro está preocupado com a formação da cidadania. A coleção está indo de acordo com o proposto nos documentos oficiais e na literatura sobre CTS, mas iremos observar posteriormente se os autores cumprem essa ideia que propagam. Na citação 5 e 6 a ideia de CTSA volta a aparecer. Na citação 2 a coleção promete abordar a questão ambiental de maneira relacionada com a tecnologia.

Novamente se percebe uma preocupação em relacionar a importância de se aprender sobre tecnologia com a cidadania e perceber os impactos e influências da tecnologia na sociedade, prometendo levar o aluno a uma compreensão crítica sobre a tecnologia, que o permita avaliar sobre o seu lugar na sociedade, posicionar-se e repensar sobre as suas escolhas. 
A coleção 2 possui uma grande preocupação em prometer que o aluno aprenderá sobre tecnologia e desenvolverá a cidadania. Isso pode estar relacionado com a questão de que os autores dessa coleção são importantes referências brasileiras na área de CTS e costumam classificar o livro como uma obra CTS. Entretanto é necessário analisar se o livro se encaixa no que vem prometendo em relação à tecnologia.

Essa ideia também se repete nos exemplos 4 e 7, onde os autores voltam a afirmar a importância de se aprender tecnologia para o exercício da cidadania e tomada de decisões conscientes e que a tecnologia está ligada à sociedade e ao meio ambiente. Também já se percebe em 4 uma visão pessimista da tecnologia, dizendo que a mesma causa desequilíbrios ambientais. O contrário ocorre em 3 , onde se aborda que a tecnologia causa uma melhor qualidade de vida, mostrando uma visão otimista.

Os livros da coleção 1 apresentam praticamente a mesma apresentação nos três livros e também fazem uma referência à abordagem da tecnologia. A coleção 4 apresenta a mesma apresentação e essa referência aparece duas vezes na apresentação dos livros (tabela 3).

Tabela 3. Trechos que abordam a tecnologia na apresentação das coleções 1 e 4

(8) Assim, o estudo da Química, em particular, vai lhe fornecer informações que farão você compreender melhor o funcionamento do seu corpo e do mundo em que vive. Essas informações ajudarão você a exercer efetivamente sua cidadania e a ter consciência de suas escolhas — incluindo o uso da tecnologia -, pois será capaz de avaliar o impacto dessas escolhas tanto no meio ambiente quanto na sua saúde. (C1, L1, L2, L3, p. 3)

(9) Cada capítulo da coleção é um estímulo para que você estabeleça uma relação entre algumas situações vivenciadas em seu cotidiano e os fenômenos químicos que as explicam. Esse convite é feito a todo momento: nas aberturas de unidades e capítulos, nas atividades experimentais e nas leituras que envolvem ciência, tecnologia e sociedade. (C4, L1, L2, L3, p. 3)

(10) Aqui você terá elementos para, individualmente ou em grupo, posicionar-se criticamente ante os impactos que a tecnologia e as atividades industriais impõem ao meio ambiente e analisar, com base nos conceitos desenvolvidos, os meios para minimizar esses impactos. (C4, L1, L2, L3, p. 3)

Essas informações aparecem nos três livros de cada coleção. Podemos perceber nas citações acima, que há uma busca por justificar a aprendizagem da química, os autores buscam dizer aos alunos porque aprender química é importante, para justificar o ensino de química nas escolas e a importância do referido livro didático. Para justificar a aprendizagem da Química, os autores utilizam a questão da tecnologia, assim como outras questões como saúde, meio ambiente e sociedade.

Em 8, 9 e 10, as coleções anunciam ao aluno que ele irá estudar sobre tecnologia, as relações CTS e terá a oportunidade de adquirir conhecimentos para uma formação cidadã. É 
possível perceber uma associação da tecnologia com impactos no meio ambiente, na sociedade e na saúde da população, já apresentando que a tecnologia pode ter seus malefícios e que o aluno deve compreendê-los e se posicionar criticamente em relação a isso, algo que se mostrará presente durante todos os livros das coleções, onde é possível identificar diversas reflexões a respeito dos impactos ambientais e sociais associados à tecnologia.

A coleção 3 é a única que não aborda na apresentação dos livros que trabalhará a questão da tecnologia. Porém, a coleção 3 contém um "box" intitulado "O que você vai estudar neste volume". Nesse "box" é apresentada a relação entre ciência e tecnologia.

(11) Neste livro, procuramos abordar temas que julgamos fundamentais para a construção de uma base conceitual que possibilite uma visão de conjunto da Química. Procuramos abordar esses temas de forma contextualizada, buscando articular a construção do conhecimento químico e sua aplicação a problemas sociais, ambientais e tecnológicos (C3, L1, L2, L3, p.10).

(12) Nesse mundo tecnológico em que vivemos, o químico é um grande "artífice da matéria", pois é capaz de transformá-la para obter produtos com constituição e propriedades específicas que permitem sua utilização para finalidades bem determinadas (C3, L1, L2, L3, p.10).

Em 11 e 12, a coleção 3, como as anteriores, busca estabelecer relações entre ciência e o mundo tecnológico, buscando formar alunos que possam refletir sobre a presença da tecnologia na sociedade. É comum nas quatro coleções a tentativa de justificar a aprendizagem da Química utilizando a tecnologia, pois os livros utilizam artefatos tecnológicos e a tecnologia para justificar a aprendizagem de conceitos, leis e teorias da Química. Essa é uma maneira que os autores encontram para dizer que aprender Química é importante. Isso ocorre porque, muitas vezes, o aluno faz o questionamento do por que é importante aprender determinado conteúdo e para que ele irá utilizá-lo na sua vida, dessa forma, é comum associar o ensino de química com a utilização e a compreensão do funcionamento de artefatos tecnológicos, como uma justificativa para o ensino dessa disciplina. Fourez (2003, p. 110) afirma que:

[...] os jovens de hoje parecem que não aceitam mais se engajar em um processo que se lhes quer impor sem que tenham sido antes convencidos de que esta via é interessante para eles ou para a sociedade. Isto vale para todos os cursos, mas talvez ainda mais para a abstração científica. [...] muitos jovens de hoje pedem que lhes seja mostrado de início a importância - cultural, social, econômica ou outra - de fazer este desvio. Mas nós, seus professores, estamos prontos e somos capazes de lhes mostrar esta importância? 
De acordo com Fourez (2003) os alunos precisam de uma justificativa do porque é importante determinada disciplina e conteúdo. Fourez (2003) destaca que os alunos de hoje precisam ver sentido no que aprendem. Eles desejam um ensino de ciências que os ajude a compreender o mundo com os seus olhos e não passar a ver o mundo com os olhos dos cientistas. Portanto, os livros estão buscando uma maneira de prometer ao aluno que a aprendizagem da química será importante, pois a química está presente na tecnologia e em artefatos tecnológicos e justificam que isso auxiliará os alunos a ter conhecimentos para exercer melhor sua cidadania e se posicionar com relação à tecnologia na sociedade.

Apesar dos cidadãos não compreenderem o que é tecnologia, essa causa grande fascínio a todos, mais ainda do que a ciência. Fourez (2003) aponta que se perguntarmos nas ruas quais os avanços recentes da ciência, os cidadãos apontarão artefatos tecnológicos, como objetos ligados a informática. Dessa forma, a tecnologia acaba fascinando muito mais as pessoas que a ciência, e ela consegue ser percebida no cotidiano das pessoas de forma muito mais fácil, portanto se torna um ótimo argumento para aprender ciência.

A coleção 3 foi a única que não tinha, logo na apresentação, a indicação de que iria abordar a questão da tecnologia durante os livros. Essa indicação aparece apenas posteriormente, durante a obra. Porém, essa coleção foi a que apresentou menos referências sobre a questão da tecnologia. A coleção 2 foi a que mais apareceu na apresentação dos livros a referência da tecnologia, prometendo duas vezes nos livros do primeiro e terceiro ano e três vezes no livro do segundo ano que irá abordar tecnologia. A coleção 2 também foi a que mais exemplos de abordagem da tecnologia apresentou. Essa referência também aparece logo no início do livro do primeiro ano:

(13) Por isso, entre outros motivos, o estudo da Química é fundamental em nossas vidas. Afinal, vivemos em uma sociedade tecnológica em que a quase totalidade dos materiais utilizados é obtida por meio de processos químicos. Vamos, a seguir, estudar um pouco como a Química está inserida nesse mundo tecnológico (C2, L1, p. 16).

Agora serão apresentadas as abordagens de tecnologia encontradas nos livros didáticos analisados e se buscará comparar com o que é dito na apresentação. 


\subsubsection{O SIGNIFICADO DA TECNOLOGIA}

Serão agrupadas nessa família as categorias que possuam alguma relação com o significado da tecnologia. Foram criadas quatro categorias para discutir os significados de tecnologia apresentados nos livros didáticos: tecnologia como ciência aplicada; ciência como derivada da tecnologia; tecnologia ou técnica e discussão do significado da tecnologia. A categoria que mais aparece nos livros didáticos é da tecnologia como ciência aplicada, como pode ser visto no gráfico 1 . O gráfico 1 mostra a quantidade de exemplos dos livros didáticos em que as coleções apresentam uma discussão em que o significado da tecnologia é evidenciado. Em $79 \%$ dos exemplos apresentados pelos livros didáticos a tecnologia é vista como ciência aplicada.

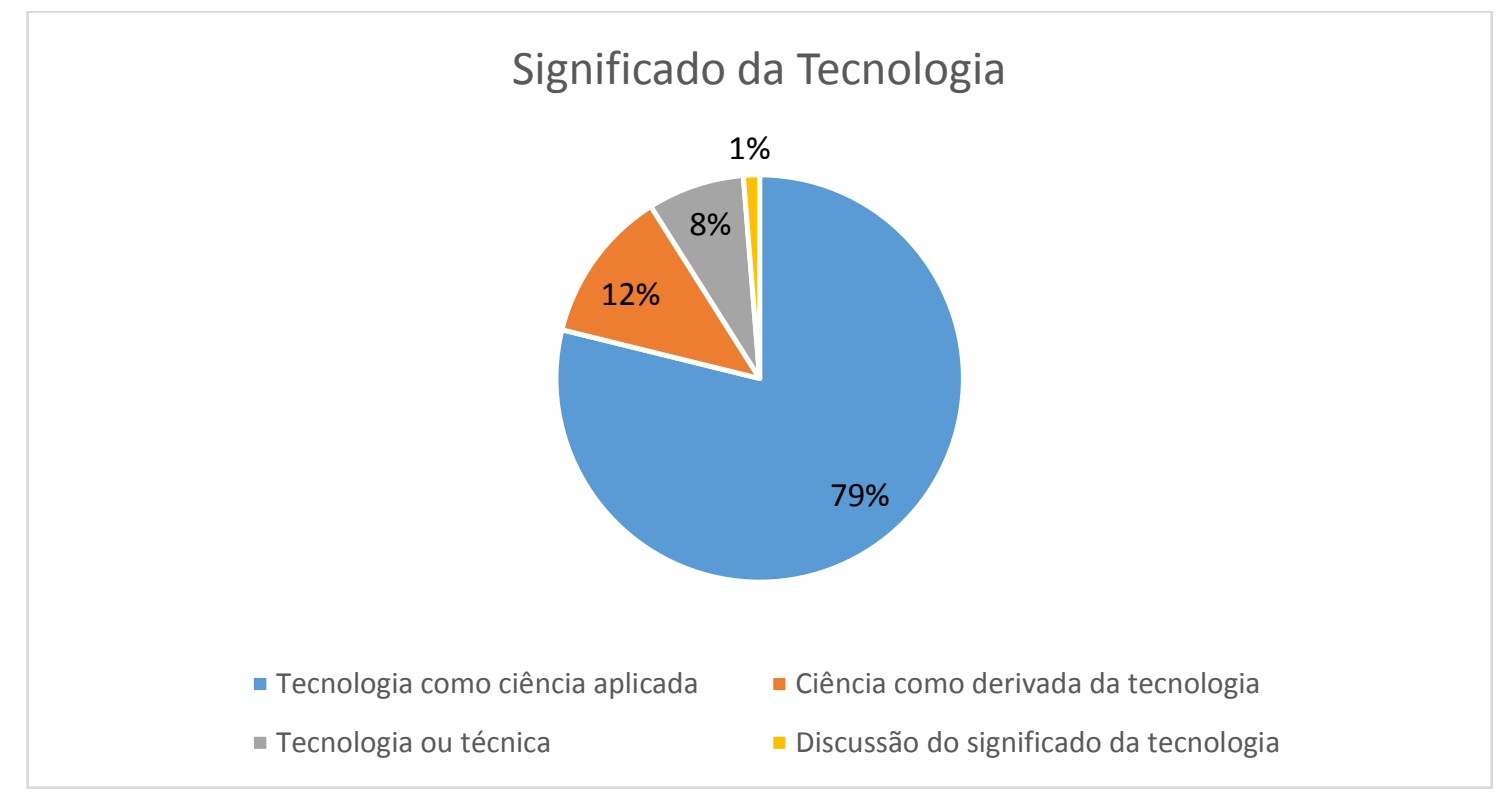

Gráfico 1: Quantidade de exemplos do livro em que é discutido o significado da tecnologia

\subsubsection{Tecnologia como ciência aplicada}

Essa é a concepção de tecnologia mais comum apontada pela literatura. Cupani (2006, 2013) aponta que não há um consenso em relação ao conceito de tecnologia, mas que todos os pesquisadores concordam que ela não pode ser vista apenas como ciência aplicada, embora ela utilize os conhecimentos científicos. $\mathrm{O}$ fato de utilizar conhecimentos científicos não 
significa que a tecnologia se resume a isso, ela também produz novos conhecimentos e é uma área de conhecimento diferente da ciência. Apesar dessa visão não ser compartilhada entre os filósofos da área de filosofia da tecnologia, essa é uma concepção bastante comum entre os professores, como aponta Fourez (2003), Ricardo, Custódio e Rezende (2007), Silva (2003), Firme e Amaral (2008), Kist e Ferraz (2010). Ricardo (2015) também verificou que essa concepção é bastante comum nos livros didáticos de Física brasileiros. Nos livros didáticos de Química analisados também foram encontrados diversos exemplos dessa concepção.

Nessa concepção, a tecnologia ou os artefatos tecnológicos são apresentados como aplicações diretas de conceitos, leis e teorias científicas. Segundo Veraszto et al. (2008) essa concepção leva à ideia de que a tecnologia é um conhecimento prático que deriva exclusivamente do conhecimento teórico científico e que vai crescendo linearmente ao lado do conhecimento científico. Veraszto et al. (2008) também chama essa ideia de concepção intelectualista de tecnologia.

Essa concepção também remete à ideia de que a ciência vai se desenvolvendo e linearmente vai desenvolvendo a tecnologia, como se a tecnologia ou um artefato fosse uma aplicação direta da ciência. A tecnologia seria vista como derivada da ciência. Essa ideia é chamada de modelo linear de desenvolvimento científico, que significa que quanto mais ciência, mais tecnologia e mais qualidade de vida para a população.

Segundo Veraszto et al. (2008), nessa teoria o desenvolvimento científico é visto como acumulativo, surgindo teorias científicas cada vez mais amplas e gerais que vão substituindo a ciência passada e sendo aplicadas para surgir novas tecnologias. Todas as teorias serão anteriores às tecnologias e não existe tecnologia sem teoria. Assim, haveria um modelo hierárquico, onde a tecnologia seria subordinada às ciências. A ciência teria um status mais importante e a tecnologia seria apenas a aplicação dela.

Como já foi visto anteriormente, existem diversas críticas de autores em relação a essa teoria, pois a partir dela não é possível visualizar toda a complexidade que envolve o conhecimento tecnológico. Também não é possível perceber que apesar de o conhecimento tecnológico utilizar, em alguns casos, o conhecimento científico, o conhecimento tecnológico também possui suas próprias regras, produz conhecimentos próprios, possui suas próprias leis e teorias e não pode ser considerado como uma ramificação do conhecimento científico. Segundo Niezwida (2009), a concepção de ciência aplicada se expandiu para os currículos e 
textos escolares, que geralmente limitam a tecnologia a uma associação com os conhecimentos científicos.

Nesses exemplos, a tecnologia é apresentada como uma aplicação direta da química. Os exemplos do livro não estão errados, mas eles não são suficientes para explicar todo o processo tecnológico envolvido na criação e funcionamento do artefato, reduzindo o mesmo a uma aplicação direta da ciência. Não se aborda como a tecnologia cria novos conhecimentos. Trata-se de uma tentativa de evidenciar apenas a presença do conteúdo químico que está sendo estudado no momento, citando o exemplo de algum processo ou artefato tecnológico. Essa também pode ser encarada como uma tentativa de justificar a aprendizagem da química, dizendo que determinado conteúdo químico é importante por ser aplicado em determinado artefato tecnológico.

$\mathrm{Na}$ situação abaixo podemos perceber de forma ainda mais clara essa concepção presente no livro.

(14) Na verdade, o que muitas vezes o químico faz é procurar entender a natureza e testar meios de reproduzir o fenômeno que o interessa em laboratório (em pequena escala), introduzindo ou não alguma modificação, para, mais tarde, o engenheiro químico adaptar o processo para a indústria (que vai reproduzí-lo em larga escala). (C1, L1, p. 12)

Podemos perceber a concepção de que os processos industriais são frutos da aplicação da ciência, onde primeiramente a ciência é estudada em laboratório para posteriormente ser aplicada na indústria por engenheiros. Os produtos produzidos pela indústria seriam dessa forma a aplicação da ciência. Também é subentendida a ideia de desenvolvimento linear da tecnologia, como se a mesma sempre fosse resultado da ciência e, portanto, o desenvolvimento da ciência viesse sempre primeiro.

Essa concepção também aparece de maneira bastante clara em outros trechos das coleções. Em alguns momentos, os livros didáticos discutem qual é o significado da química, como a química contribui para a sociedade e qual o trabalho de um químico. Nesses momentos, as coleções costumam associar o trabalho do químico com a produção de novas tecnologias, como se tudo que o químico pesquisasse em laboratório ele já tivesse interesse de aplicar em tecnologias futuras e imediatamente depois essas ideias já seriam aplicadas em artefatos tecnológicos.

Resultados e Discussões 
Essa visão leva os alunos à crença de que a tecnologia se resume a conhecimentos científicos e não os permite compreender a tecnologia como uma forma de conhecimento. Nesse discurso também é expressa a ideia de desenvolvimento linear de ciência e tecnologia, onde a ciência sempre precede a tecnologia. Primeiro se teria o conhecimento teórico (ciência) e ele originaria o conhecimento prático (tecnologia). Não é possível, neste caso, a existência de uma tecnologia sem uma teoria científica anterior para respaldá-la.

Segundo Silva (2003) e Acevedo et al. (2003), a tecnologia como ciência aplicada é respaldada em um modelo positivista de ciência, que significa que quanto mais se estudar a ciência, mais tecnologia será obtida e assim uma melhor qualidade de vida. Acevedo et al. (2003) ressaltam que a tecnologia utiliza métodos de investigação similares aos da ciência e muitos conhecimentos advindos da ciência, o que não podemos considerar é que a tecnologia se resuma apenas a aplicação de conhecimentos científicos. Isso porque a tecnologia faz um tratamento de reelaboração e reconstrução dos conhecimentos científicos para adaptá-los e integrá-los a outros conhecimentos, formando assim o conhecimento tecnológico. Por outro lado, a ciência também utiliza conhecimentos da tecnologia, compartilhando métodos, conhecimentos teóricos, conceitos, modelos e analogias da tecnologia.

Na tabela 4 estão apresentados alguns dos exemplos contidos no livro da visão da tecnologia como ciência aplicada, no momento em que o livro aborda a definição de química e explica o trabalho do químico. Os livros didáticos também possuíam outros exemplos, entretanto aqui só serão expostos alguns.

Tabela 4. Tecnologia como ciência aplicada

(15) Nesse mundo tecnológico em que vivemos, o químico é um grande "artífice da matéria", pois é capaz de transformá-la para obter produtos com constituição e propriedades específicas que permitem sua utilização para finalidades bem determinadas. (C3, L3, p.10)

(16) Química é o ramo da ciência que estuda a matéria, suas propriedades, estrutura e transformações. A Química está presente em tudo - nos alimentos, nas roupas, nos livros, no piso e nas paredes da sala de aula, nos aparelhos de TV, na água, na areia, no ar. A própria manutenção da vida (respiração, digestão de alimentos, etc.) envolve processos químicos. (C4, L1, p. 13)

(17) A Química está tão presente na vida humana, que é difícil imaginar a vida sem ela. Os produtos químicos têm inúmeras aplicações, entre as quais se ressalta fabricação dos computadores, que constituem a revolução dos tempos atuais. (C2, L1, p. 20)

(18) [...] os químicos contribuem para a transformação do mundo em que vivemos. Diariamente, eles descobrem e sintetizam (produzem em laboratório) novas substâncias por meio de reações químicas. Muitas são posteriormente utilizadas na fabricação de novos materiais; outras entram na composição de medicamentos, de produtos de limpeza, de alimentos (para conservar e melhorar o sabor, a aparência ou o teor nutritivo) e de uma infinidade de outros produtos que consumimos diariamente. (C2, L1, p. 96)

(19) $\mathrm{Na}$ produção de automóveis, os químicos contribuem para o desenvolvimento de materiais mais resistentes, seguros, leves e atraentes. (C2, L1, p. 97) 
Em exemplos como o 15 e 18 se dá a entender que o trabalho do químico é desenvolver substâncias já com uma finalidade pré-determinada, que seria uma aplicação tecnológica, essa é a visão de que os químicos já visualizam o interesse tecnológico em seus estudos. Em 19 coloca-se a ideia de que os químicos estavam buscando novos materiais para posteriormente aplicá-los na construção de automóveis. Também em 18 é difundida a ideia de que a química produziu novos produtos e depois os aplicou diretamente no cotidiano. Em 16 se coloca que a química está presente em tudo, inclusive nos artefatos tecnológicos, utilizando isso como justificativa da importância da química. Dizer que a química está presente em "tudo" é algo bastante vago e nem sempre conseguimos perceber esse "tudo" na escola. Em 17 se atribui uma visão positiva da química, devido ela estar presente no meio tecnológico, atribuindo a ela uma melhoria na qualidade de vida e que hoje é impossível viver sem ela. Nesse caso, é apontado que o ser humano depende da tecnologia e consequentemente da química para sua melhor qualidade de vida.

A visão da tecnologia como ciência aplicada, embora seja a mais difundida pelos livros didáticos, pode levar a visões errôneas sobre o conhecimento tecnológico. Segundo Ferreira, Gil-Pérez e Vilches (2006), essa visão de tecnologia é bastante superficial, ignora o processo de construção do conhecimento tecnológico, reduzindo-o apenas ao científico. Surge no contexto uma visão hierárquica, a ciência seria o âmbito da racionalidade e a tecnologia o âmbito manual. A tecnologia seria inferior à ciência. Essa subvalorização da tecnologia prejudica o ensino de tecnologia e que ocorra uma efetiva discussão das relações CTS, resumindo-se a uma enumeração de aplicações dos conhecimentos científicos.

Acevedo et al. (2003) destacam que uma consequência da visão de tecnologia como ciência aplicada é considerar que as teorias de um tecnólogo ou engenheiro são menos complexas que as da ciência. O saber científico teria superioridade em relação ao saber tecnológico. A principal finalidade dos tecnólogos seria a produção de artefatos tecnológicos e não a produção de conhecimentos teóricos. Para muitas pessoas, é difícil perceber que a tecnologia também produz conhecimentos, embora a racionalidade científica seja diferente da racionalidade tecnológica. Os critérios de validade do conhecimento tecnológico não se preocupam tanto com explicações como na ciência, mas se preocupam com que aquele conhecimento funcione na prática e tenha utilidade. 
Dentro dessa categoria - Tecnologia como ciência aplicada - agora serão explicitados casos específicos em que a tecnologia ou os artefatos tecnológicos são vistos como uma aplicação direta de conhecimentos científicos, ignorando os conhecimentos específicos dos processos tecnológicos.

\subsection{Artefatos tecnológicos que utilizam conceitos, teorias e leis da química}

Neste ponto serão apresentados alguns trechos do livro em que são citados exemplos de artefatos tecnológicos e os conceitos, teorias e leis da química utilizados no processo de produção ou funcionamento desses artefatos. Nesses exemplos, não são discutidos os processos tecnológicos, conhecimentos tecnológicos envolvidos ou questões mais amplas da tecnologia. A tecnologia é apresentada apenas como artefatos tecnológicos que utilizam conhecimentos científicos. Os artefatos tecnológicos são utilizados nos exemplos como uma forma de expor o conteúdo químico, explicando quais conceitos, leis e teorias da química são utilizados na fabricação de determinado artefato.

Nesses momentos do livro dedicados à tecnologia, a preocupação não é em explicar a tecnologia ou o funcionamento dos artefatos tecnológicos em questão, mas o objetivo é apenas ilustrar certos conhecimentos científicos, teorias, conceitos e leis da química que estão sendo ensinadas naquele capítulo e como forma de ilustração ou "curiosidade" são citados alguns exemplos de artefatos tecnológicos. Segundo Acevedo (2003), o funcionamento de um produto tecnológico não pode ser explicado com base em uma única teoria científica, porque seu funcionamento é complexo e necessita de diversas bases. Dessa forma, o ensino de ciências quase nunca explica realmente o funcionamento de um artefato tecnológico, ficando apenas em explicações parciais de uma teoria científica apenas.

Esses exemplos não levam o aluno a compreender sobre tecnologia ou refletir sobre a relação da tecnologia com a sociedade, pois não são feitos questionamentos, não são lançadas problemáticas em relação ao artefato para o aluno refletir e também não é explicado de forma mais profunda como funcionam os conhecimentos científicos e tecnológicos envolvidos no processo, apenas aparece o caráter de exemplificação, mostrando alguns artefatos que utilizam conteúdos científicos.

Resultados e Discussões 
Nos exemplos abaixo, também não é explicado profundamente o funcionamento do artefato tecnológico em questão ou como ele é utilizado, apenas é citado como uma forma de exemplificação de onde aquele conceito, lei ou teoria da química é aplicada. O aluno conhecerá apenas uma parte do processo, alguma teoria química relacionada, mas não saberá como o artefato realmente funciona.

Essa também pode ser considerada uma forma de justificar a aprendizagem de um conteúdo químico ou da química, expondo que esse conteúdo é importante, pois está presente em determinado artefato utilizado no cotidiano ou importante para a sociedade, porém sem explicar de forma mais aprofundada, sem levar o aluno a compreender o processo tecnológico envolvido.

A tabela 5 abaixo mostra os trechos do livro em que são citados os artefatos tecnológicos que utilizam conceitos químicos. Em cada coluna se encontram trechos de uma das coleções. Optou-se por não apresentar todos os exemplos contidos nas coleções, são apresentados apenas alguns dos trechos para exemplificar a categoria.

Tabela 5. Artefatos tecnológicos que utilizam conceitos químicos

\begin{tabular}{|c|c|c|c|}
\hline Coleção 1 & Coleção 2 & Coleção 3 & Coleção 4 \\
\hline $\begin{array}{lr}\text { (20) Outro exemplo } \\
\text { de } & \text { catálise } \\
\text { heterogênea é a que } \\
\text { ocorre } \\
\text { conversores } \\
\text { catalíticos } \\
\begin{array}{l}\text { automóveis. (C1, L2, } \\
\text { p. 182) }\end{array}\end{array}$ & $\begin{array}{l}(23) \text { Todas as } \\
\text { tecnologias mais } \\
\text { avançadas, como a } \\
\text { robótica, são derivadas } \\
\text { de conhecimentos da } \\
\text { estrutura dos } \\
\text { materiais. (C2, L1, } \\
\text { p.16) }\end{array}$ & $\begin{array}{l}\text { (26) Telefones celulares, } \\
\text { brinquedos, relógios, rádios } \\
\text { portáteis e lanternas são } \\
\text { alguns exemplos de objetos } \\
\text { cujo funcionamento depende } \\
\text { de pilhas e baterias. O controle } \\
\text { remoto do aparelho de TV } \\
\text { funciona por tanto tempo com } \\
\text { duas pilhas pequenas que, às } \\
\text { vezes, essas se estragam, } \\
\text { vazam e oxidam partes do } \\
\text { controle remoto sem nos } \\
\text { darmos conta e, ainda assim, o } \\
\text { comando da TV funciona. Por } \\
\text { isso, é recomendável trocá-las } \\
\text { de seis em seis meses. Há } \\
\text { muitos tipos de pilhas e } \\
\text { baterias. Vamos considerar, } \\
\text { nesta etapa, um tipo de pilha } \\
\text { comum: a de óxido de zinco e } \\
\text { manganês, também conhecida } \\
\text { como pilha de Leclanché. (C3, } \\
\text { L2, p. 229) }\end{array}$ & $\begin{array}{l}\text { (29) Nesta unidade serão } \\
\text { estudadas } \\
\text { transformações químicas } \\
\text { que resultam de um } \\
\text { processo de transferência } \\
\text { de elétrons, as quais são } \\
\text { denominadas reações de } \\
\text { oxirredução. Essas reações } \\
\text { são responsáveis, por } \\
\text { exemplo, pela geração da } \\
\text { imagem nos antigos filmes } \\
\text { fotográficos. (C4, L2, p. } \\
\text { 200) }\end{array}$ \\
\hline $\begin{array}{lr}(21) \quad \text { Nos aviões } \\
\text { pressurizados, } \\
\text { pressão interna é }\end{array}$ & $\begin{array}{l}\text { (24) Com o avanço do } \\
\text { conhecimento acerca } \\
\text { da estrutura dos }\end{array}$ & $\begin{array}{l}\text { (27) Nas panelas de pressão, } \\
\text { as temperaturas de cozimento } \\
\text { são mais altas porque a }\end{array}$ & 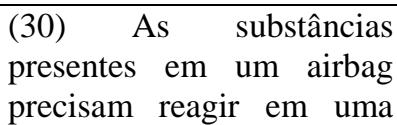 \\
\hline
\end{tabular}




\begin{tabular}{|c|c|c|c|}
\hline $\begin{array}{l}\text { maior que a pressão } \\
\text { externa. Se por algum } \\
\text { motivo a fuselagem } \\
\text { romper, tudo que está } \\
\text { dentro do avião será } \\
\text { sugado para fora, } \\
\text { justamente por causa } \\
\text { da diferença de } \\
\text { pressão. (C1, L1, } \\
\text { p.29) }\end{array}$ & $\begin{array}{l}\text { materiais, por } \\
\text { exemplo, é possível } \\
\text { gerar todo um aparato } \\
\text { tecnológico para } \\
\text { processar informações } \\
\text { por meio de máquinas } \\
\text { incríveis, conhecidas } \\
\text { como computadores. } \\
(\mathrm{C} 2, \mathrm{~L} 1, \mathrm{p} .16)\end{array}$ & $\begin{array}{l}\text { pressão interna pode atingir } \\
\text { valores superiores aos da } \\
\text { pressão atmosférica. (C3, L2, } \\
\text { p. } 71)\end{array}$ & $\begin{array}{l}\text { fração de segundo para } \\
\text { liberar o gás necessário } \\
\text { para inflá-lo e, com isso, } \\
\text { amortecer o impacto da } \\
\text { colisão diminuindo lesões } \\
\text { no motorista e passageiros. } \\
\text { (C4, L2, p. 98) }\end{array}$ \\
\hline $\begin{array}{l}\text { (22) Na panela de } \\
\text { pressão a água ferve a } \\
\text { uma temperatura } \\
\text { superior a } 100{ }^{\circ} \mathrm{C} \text { por } \\
\text { conta do aumento da } \\
\text { pressão. (C2, L1, } \\
\text { p.33) }\end{array}$ & $\begin{array}{l}(25) \text { A bateria de } \\
\text { telefone celular } \\
\text { produz energia com } \\
\text { base em reações } \\
\text { químicas ocorridas em } \\
\text { seu interior. (C2, L1, } \\
\text { p.96) }\end{array}$ & $\begin{array}{l}\text { (28) Quando aquecemos um } \\
\text { alimento no forno de micro- } \\
\text { ondas, usamos outra forma de } \\
\text { radiação - as micro-ondas. } \\
\text { Quando você sintoniza seu } \\
\text { rádio na estação preferida, } \\
\text { logo ouvirá o locutor dizer: } \\
\text { "você está ligado na 93.8", por } \\
\text { exemplo. Esse número } \\
\text { expressa a frequência, em } \\
\text { MHz (megahertz), da radiação } \\
\text { eletromagnética, nesse caso, } \\
\text { "ondas de rádio". Ao } \\
\text { sintonizarmos o televisor nos } \\
\text { canais, na verdade estamos } \\
\text { sintonizando uma frequência } \\
\text { de ondas eletromagnéticas. } \\
\text { (C3, L1, p. } 175\end{array}$ & $\begin{array}{l}\text { (31) Uma forma segura de } \\
\text { determinar a extensão de } \\
\text { uma fratura, por exemplo, é } \\
\text { o uso de equipamentos de } \\
\text { raios X. Para que avanços } \\
\text { tecnológicos como esse } \\
\text { pudessem estar presentes, } \\
\text { não só na medicina, mas } \\
\text { também, por exemplo, na } \\
\text { produção industrial, um } \\
\text { grande passo teve de ser } \\
\text { dado pelos cientistas: a } \\
\text { concepção científica do } \\
\text { modelo atômico. (C4, L1, } \\
\text { p. 84) }\end{array}$ \\
\hline
\end{tabular}

Podemos perceber nos casos da tabela 5, que em nenhum momento o objetivo das citações é que o aluno aprenda como ocorreu o processo tecnológico envolvido, ou os conhecimentos tecnológicos, ou entenda o funcionamento dos artefatos tecnológicos em questão. O objetivo das citações acima é apenas evidenciar o conceito químico ou o conteúdo estudado no capítulo e mostrar que esse conteúdo tem uma "aplicação". Nesse caso, a tecnologia não tem sido utilizada como um conteúdo ou assunto a ser discutido, mas ela é vista apenas como uma forma de ilustrar os conteúdos químicos que estão sendo estudados naquele momento, evidenciando a ciência e deixando a tecnologia como dependente dela.

O computador e a máquina de radiografia são os artefatos tecnológicos mais citados como exemplo de aplicação tecnológica de conceitos químicos. Se formos pensar no computador, seu funcionamento depende de diversos conhecimentos e considerá-lo apenas uma aplicação de conhecimentos químicos é ignorar todos os demais conhecimentos envolvidos no seu funcionamento.

Nos exemplos da tabela 5 se percebe uma focalização nos produtos tecnológicos, sem dar ênfase aos processos e impactos sociais. Segundo Veraszto et al. (2008), muitas vezes, a 
tecnologia é entendida apenas como seus produtos tecnológicos. A produção tecnológica consiste apenas nos equipamentos, ferramentas e artefatos gerados por ela. Isso pode levar a ideia de que saber utilizar um equipamento pode tornar a pessoa informada sobre tecnologia, não levando as pessoas a refletir sobre aspectos sociais relacionados aos artefatos.

\subsection{Elementos ou substâncias químicas presentes em artefatos tecnológicos}

O livro também contém diversos exemplos em que é apresentado um artefato tecnológico e então são citados os elementos químicos, substâncias químicas e materiais do qual o artefato é fabricado (tabela 6). Nesses exemplos, não é explorado o processo tecnológico das aplicações, como elas ocorrem ou o funcionamento do artefato, apenas são mostrados os materiais químicos envolvidos no artefato. Esse tipo de exemplo é muito comum nas coleções analisadas. A coleção 1 e 4 são as que possuem mais exemplos desse tipo. Na tabela 6 são apresentados alguns dos exemplos encontrados nas coleções.

Tabela 6. Artefatos tecnológicos e seus materiais químicos

\begin{tabular}{|c|c|c|c|}
\hline Coleção 1 & Coleção 2 & Coleção 3 & Coleção 4 \\
\hline $\begin{array}{l}\text { (32) As lâmpadas } \\
\text { halógenas são lâmpadas } \\
\text { incandescentes que } \\
\text { contêm em seu interior } \\
\text { um halogênio, em geral } \\
\text { iodo gasoso. A função } \\
\text { do iodo é recuperar o } \\
\text { tungstênio que sublima } \\
\text { do filamento, e poderia } \\
\text { se depositar no bulbo, } \\
\text { escurecendo a lâmpada. } \\
\text { (C1, L2, p. 216) }\end{array}$ & $\begin{array}{l}\text { (36) Os fenóis têm } \\
\text { aplicações diversas e são } \\
\text { matéria-prima utilizada } \\
\text { na produção de resinas e } \\
\text { explosivos. No entanto, } \\
\text { sua maior utilização é } \\
\text { como bactericida. Com } \\
\text { esse objetivo, passou a } \\
\text { ser largamente utilizado } \\
\text { em hospitais, diminuindo } \\
\text { consideravelmente os } \\
\text { casos de infecção pós- } \\
\text { operatória. (C2, L3, p. } \\
\text { 74) }\end{array}$ & $\begin{array}{l}\text { (40) É pela transformação } \\
\text { dos materiais que } \\
\text { conseguimos obter } \\
\text { produtos com constituição } \\
\text { e propriedades } \\
\text { específicas, como o uso } \\
\text { do silício na fabricação de } \\
\text { chips de computadores e } \\
\text { de ligas metálicas na } \\
\text { produção de cabos de aço. } \\
\text { (C3, L1, p. 22) }\end{array}$ & $\begin{array}{l}\text { (43) Computadores, } \\
\text { aparelhos de televisão, } \\
\text { rádios e celulares } \\
\text { carregam muito mais que } \\
\text { utilidades e facilidades: } \\
\text { quase todos os metais da } \\
\text { Tabela Periódica podem } \\
\text { ser encontrados em placas } \\
\text { de circuito impresso que } \\
\text { compõem equipamentos } \\
\text { eletroeletrônicos em geral. } \\
\text { (C4, L2, p. 263) }\end{array}$ \\
\hline $\begin{array}{l}\text { (33) Um dos primeiros } \\
\text { usos do alumínio foi } \\
\text { nas aeronaves alemãs } \\
\text { zepelim da Primeira } \\
\text { Guerra Mundial. Essas } \\
\text { aeronaves eram feitas } \\
\text { de duralumínio (liga } \\
\text { constituída de } 95,5 \% \text { de } \\
\text { Al, } 3 \% \text { de Cu, } 1 \% \text { de } \\
\text { Mn e } 0,5 \% \text { de } \mathrm{Mg} \text { ), } \\
\text { inventado em } 1906 \text {, } \\
\text { cuja densidade é cerca }\end{array}$ & $\begin{array}{l}\text { (37) Air } \text { bags de } \\
\text { automóveis protegem } \\
\text { motoristas e passageiros } \\
\text { durante choque e/ou } \\
\text { colisões. O dispositivo é } \\
\text { inflado pelo gás } \\
\text { nitrogênio } \\
\text { produzido em uma reação } \\
\text { rápida, praticamente } \\
\text { instantânea, que ocorre } \\
\text { entre nitreto de sódio e } \\
\text { óxido de ferro III. Uma }\end{array}$ & $\begin{array}{l}\text { (41) Até pouco tempo, na } \\
\text { fabricação de automóveis, } \\
\text { vários acessórios, como os } \\
\text { para-choques de aço, eram } \\
\text { revestidos de cromo. Esse } \\
\text { revestimento era feito por } \\
\text { eletrodeposição, não só } \\
\text { para o embelezamento das } \\
\text { peças, mas também para } \\
\text { sua proteção contra a } \\
\text { corrosão. As peças } \\
\text { cromadas em para- }\end{array}$ & $\begin{array}{l}\text { (44) Baterias de íon lítio: } \\
\text { São as baterias mais } \\
\text { modernas de celulares. } \\
\text { Devido à baixa densidade } \\
\text { dos materiais usados, são } \\
\text { leves e apresentam } \\
\text { potencial entre } 3,0 \text { e } 3,5 \\
\text { V. A quantidade de carga } \\
\text { total gerada por uma } \\
\text { bateria (ou pilha) depende } \\
\text { da quantidade de reagente } \\
\text { presente. As baterias de }\end{array}$ \\
\hline
\end{tabular}




\begin{tabular}{|c|c|c|c|}
\hline 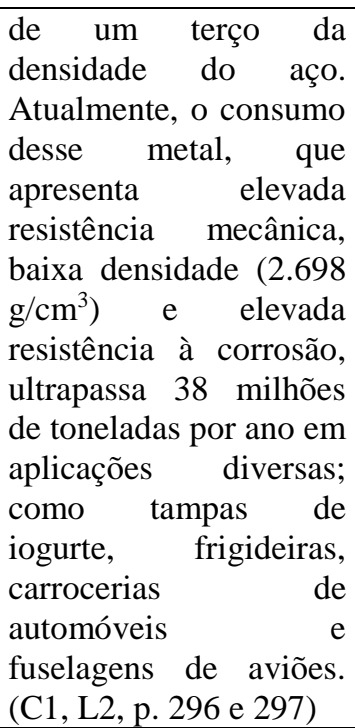 & $\begin{array}{l}\text { faísca é a energia de } \\
\text { ativação da reação. (C2, } \\
\text { L2, p. 258) }\end{array}$ & $\begin{array}{l}\text { choques de aço } \\
\text { praticamente } \\
\text { desapareceram dos } \\
\text { automóveis modernos. } \\
\text { Foram substituídas por } \\
\text { outras feitas de material } \\
\text { plástico. No entanto, a } \\
\text { cromagem de peças de aço } \\
\text { continua a ser usada para } \\
\text { produzir peças resistentes } \\
\text { a corrosão, para uso em } \\
\text { móveis, eletrodomésticos, } \\
\text { etc. (C3, L2, p. 236) }\end{array}$ & 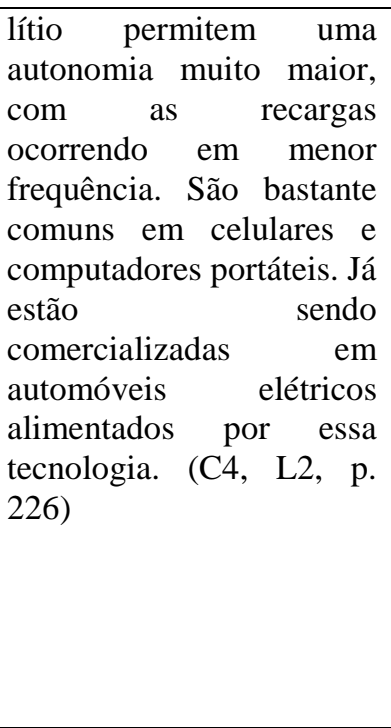 \\
\hline 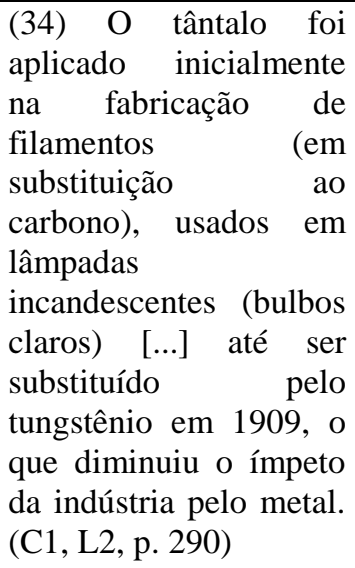 & $\begin{array}{l}\text { (38) A leveza, } \\
\text { proporcionada pela baixa } \\
\text { densidade das ligas de } \\
\text { alumínio, aliada a outras } \\
\text { propriedades dessas ligas, } \\
\text { como o alto grau de } \\
\text { dureza, permite a } \\
\text { produção de bicicletas e } \\
\text { outros veículos cada vez } \\
\text { mais velozes } \\
\text { resistentes. (C2, L3, p. } \\
\text { 227) }\end{array}$ & $\begin{array}{l}\text { (42) Uma forma muito } \\
\text { pura do silício, necessária } \\
\text { para a produção de chips } \\
\text { de computadores, é } \\
\text { também obtida a partir de } \\
\text { uma reação de } \\
\text { oxirredução } \\
\text { triclorosilano }\left(\mathrm{SiHCl}_{3}\right) \text { e } \\
\text { hidrogênio de alta pureza. } \\
(\mathrm{C} 3, \mathrm{~L} 2, \text { p. } 236)\end{array}$ & $\begin{array}{l}\text { (45) A interação entre o } \\
\text { hidrogênio e o oxigênio } \\
\text { líquido fornece a energia } \\
\text { necessária para } \\
\text { impulsionar foguetes ao } \\
\text { espaço. Contudo, essas } \\
\text { duas substâncias não } \\
\text { reagem instantaneamente } \\
\text { se colocadas em contato. } \\
\text { É necessário proporcionar } \\
\text { ao sistema uma energia } \\
\text { mínima para iniciar a } \\
\text { reação química. (C4, L2, } \\
\text { p. 85) }\end{array}$ \\
\hline $\begin{array}{l}\text { (35) O Instituto de } \\
\text { Pesquisas Energéticas e } \\
\text { Nucleares (Ipen) } \\
\text { atualmente fabrica e } \\
\text { exporta para vários } \\
\text { países o gerador de } \\
\text { tecnécio, utilizado no } \\
\text { diagnóstico de diversas } \\
\text { doenças, principalmente } \\
\text { as relacionadas ao } \\
\text { músculo cardíaco. (C1, } \\
\text { L3, p. 308) }\end{array}$ & $\begin{array}{l}\text { (39) Entre as diversas } \\
\text { aplicações industriais, } \\
\text { podemos citar a do irídio- } \\
192 \text { em controle de } \\
\text { qualidade de produtos } \\
\text { industriais, para avaliar } \\
\text { espessuras de forma } \\
\text { contínua e sem contato } \\
\text { manual. Para isso, são } \\
\text { colocados uma fonte } \\
\text { radioativa de um lado do } \\
\text { material e um sensor de } \\
\text { radiação do outro lado. } \\
\text { (C2, L2, p. } 289\end{array}$ & & $\begin{array}{l}\text { (46) O dentista William } \\
\text { Thomas Green Morton, } \\
\text { anestesiou um jovem } \\
\text { paciente com éter } \\
\text { [dietílico] para o cirurgião } \\
\text { John Collins Warren } \\
\text { retirar um tumor do } \\
\text { pescoço do rapaz. Para } \\
\text { isso foi utilizado um } \\
\text { aparelho inalador } \\
\text { idealizado pelo dentista. } \\
\text { A partir de 1847, o éter } \\
\text { começou a ser substituído } \\
\text { pelo clorofórmio, } \\
\text { introduzido } \\
\text { anestésico na Inglaterra } \\
\text { por James Simpson. [...] } \\
\text { (C4, L3, p. 128) }\end{array}$ \\
\hline
\end{tabular}

$\mathrm{Na}$ maior parte dos trechos dessa subcategoria dos livros didáticos das coleções analisadas, como em 40, não há nenhum tipo de explicação sobre o processo tecnológico 
envolvido, os conhecimentos tecnológicos ou a relação entre a sociedade. Nesses exemplos apenas é citado o material que é usado para fazer alguns artefatos tecnológicos. São citadas aplicações tecnológicas e artefatos tecnológicos como uma aplicação de materiais e elementos químicos. As informações apresentadas não estão erradas, mas não se está explicando os processos tecnológicos envolvidos e a tecnologia não se resume a aplicações de materiais. Também não é exposta a ligação da tecnologia com aspectos sociais e econômicos, obstáculos tecnológicos ou coisas do tipo. Dessa forma, a tecnologia e os artefatos tecnológicos servem apenas como exemplificação, ilustração ou curiosidade e não é realmente compreendido o processo tecnológico envolvido.

Em alguns casos, os exemplos podem levar o aluno à falsa ideia de que um artefato tecnológico inteiro é feito de uma única substância. Seria mais interessante que no lugar de disponibilizar tantos exemplos de artefatos diferentes e seus materiais, que o livro explicasse com mais profundidade apenas alguns artefatos e fornecesse mais informações sobre eles.

O aluno também pode ter a falsa ideia de que primeiramente determinado elemento ou material foi "descoberto" e estudado suas características e propriedades para depois ele ser utilizado para fabricar algum artefato, o que não necessariamente é o que acontece.

Esse tipo de exemplo busca tornar a química mais próxima do aluno, pois se cita exemplos de artefatos presentes no seu cotidiano, achando que assim se poderá aproximar a química do cotidiano do aluno. Saber apenas de qual material um artefato tecnológico é feito não auxilia em nada o aluno compreender o funcionamento desse artefato ou as implicações da tecnologia na sociedade. Exemplificar dessa forma não agrega em um ensino de química que busca a formação de cidadãos mais críticos em relação à tecnologia. Esse tipo de exemplo também não leva a resolução de nenhum tipo de problema ou a desenvolver o raciocínio no aluno. São apenas informações de pouca utilidade prática.

Nas citações 32, 33, 38 e 41 além de citar o material ou substância presente no artefato, também é explicado o porquê esse material é utilizado para a construção daquele objeto. São abordadas propriedades ou características das substâncias que o fazem ser utilizadas para fins tecnológicos. Esses exemplos não levam o aluno a refletir sobre questões importantes da tecnologia, mas podem auxiliar o aluno a compreender as propriedades dos materiais e como isso influencia no processo tecnológico. 
Em 34, 35, 36 e 37, além de citar os materiais presentes nos artefatos os livros também trazem uma breve referência em relação a aspectos econômicos e sociais. Apesar da discussão ser bastante breve, esses exemplos são mais ricos do que os anteriores. Em 34 foi citada a questão econômica em que um material foi substituído pelo outro e como isso influenciou o mercado desse material. Em 35, aborda-se o gerador de tecnécio que auxiliou no diagnóstico de doenças, expondo assim a importância social dessa tecnologia. Em 36, explica-se a importância de um material para a sociedade, auxiliando na melhoria da saúde. E em 37, explica-se a importância do airbag para evitar choques de motoristas, mostrando assim a importância social do artefato. Também em 37 é explicado de forma sucinta como ocorre a reação do airbag. Apesar da discussão ainda ser pequena, nesses exemplos se levanta um pouco de questões sociais e econômicas referentes à tecnologia.

\subsection{Explicação do funcionamento de um artefato tecnológico}

Na tabela 7 estão apresentados trechos em que o livro apresenta uma explicação do funcionamento de um artefato tecnológico de forma detalhada e não apenas superficial como nos exemplos anteriores. Nos exemplos anteriores apenas se falava de um artefato tecnológico e citava o conhecimento químico envolvido ou as substâncias, ou seja, o que estava em evidência era a química e o objetivo era compreender como a química estava inserida naquele processo. Aqui foram selecionados exemplos nos quais o que está em evidência é o artefato tecnológico. Nessas situações, os livros explicam como funciona aquele determinado artefato tecnológico, mas sem deixar a ciência de lado, sempre relacionando com os conhecimentos científicos. Na coleção 1 não foi encontrado nenhum exemplo em que a coleção explica detalhadamente o funcionamento de um artefato tecnológico. Na coleção 2 foram encontrados 2 exemplos dessa subcategoria e na coleção 3 foram 2 exemplos também. A coleção que mais apresentou passagens desse tipo foi a coleção 4, com 8 exemplos. A tabela 7 contém algumas citações que ilustram essa subcategoria.

Resultados e Discussões 
Tabela 7. Explicação do funcionamento de um artefato tecnológico

\begin{tabular}{l} 
Coleção 2 \\
\hline (47) Em elevadores há sensores \\
que, sob a ação de radiação \\
ultravioleta, produzem sinais \\
elétricos. Quando alguém impede \\
a passagem da radiação, o sinal \\
elétrico é interrompido e o \\
comando de fechar a porta do \\
elevador não é acionado. (C2, L3, \\
p. 292)
\end{tabular}
p. 292)
(48) Diferentemente dos fornos elétricos ou a gás, o forno de micro-ondas não fornece calor: ele gera radiações com frequência de $2,45 \cdot 109$ hertz. No forno, essas radiações são direcionadas ao compartimento onde ficam os alimentos, e elas atuam nas moléculas de água presentes nos alimentos. As moléculas absorvem as radiações e, com isso, aumentam a vibração de suas ligações, causando aquecimento. Como as micro-ondas atuam basicamente em moléculas de água, alimentos ou recipientes que não contenham água não são aquecidos. Por causa da capacidade de penetração dessa radiação, alimentos são cozidos por inteiro, e não a partir da superfície, como nos fornos a calor. (C2, L2, p. 112)
Coleção 3

(49) Ao observar um termômetro clínico, você vai perceber que há um estreitamento na coluna capilar. Quando o termômetro é aquecido, o mercúrio se dilata e, pelo efeito da capilaridade, sobe. Quando a medida termina, o mercúrio não pode continuar seu caminho ascendente e, por causa do estreitamento, também não retorna ao bulbo. $\mathrm{O}$ estreitamento do capilar cria condições físicas para que se estabeleça um "jogo de forças", de tal forma que o peso da coluna de mercúrio não seja suficiente para vencer a tensão superficial na interface entre a parte mais larga e a parte mais estreita do capilar. Por isso, o fluxo do mercúrio cessa, e a coluna permanece marcando a temperatura, como é desejável para um termômetro clínico. (C3, L2, p. 66)

(50) O airbag é um dispositivo constituído por uma bolsa inflável de poliamida que é acionada quando o carro bate. Ele foi projetado para absorver o choque de uma colisão em acidentes automobilísticos, diminuindo o impacto que uma forte desaceleração pode provocar na coluna vertebral, na cabeça ou no dorso do motorista e do passageiro, por causa da tendência do corpo de continuar o movimento para a frente quando o veículo é desacelerado. (C3, L2, p. 127)
Coleção 4

(51) Nos aparelhos antigos, ainda muito usados, a formação da imagem ocorre devido a um tubo de raios catódicos acoplado à tela como mostrado a seguir. Quando submetidos à alta tensão, os elétrons provenientes do cátodo dirigem-se para o ânodo, que apresenta a forma de um cilindro oco e que permite a passagem de um feixe de elétrons. O impacto desse feixe sobre uma tela coberta de material fosforescente resulta em emissão de luz, que observamos como imagem. $\mathrm{O}$ feixe forma imagens ao percorrer cada uma das pequenas unidades (pixels) dessa tela. $\mathrm{O}$ brilho responsável pela imagem que observamos na tela depende da tensão elétrica aplicada, que controla a intensidade do feixe de elétrons emitidos pelo cátodo. A cor da imagem depende de qual material fosforescente está sendo excitado, se o azul, o verde ou o vermelho. A combinação dessas três cores compõe a cor de cada um dos pixels. (C4, L1, p. 88)

(52) Nesses equipamentos, o calor gerado com a queima de combustível (carvão) transformava a água líquida em vapor. O gás formado era então conduzido a um cilindro, expandia-se e empurrava o êmbolo. Essa transformação possibilitou, por exemplo, o bombardeamento de água de minas de carvão e de ferro alagadas, bem como promoveu o deslocamento mais rápido de embarcações e o desenvolvimento de locomotivas. (C4, L1, p. 280) 
Em 47, o livro explica o funcionamento do elevador, relacionando com conhecimentos científicos envolvidos no processo de funcionamento. Em 48, é explicado o funcionamento do forno micro-ondas e feito uma comparação do mesmo com fornos convencionais. Em 49 é explicado o funcionamento do termômetro e relacionado com o conhecimento científico. Em 50 se explica o funcionamento do airbag com essa citação e também com um box explicando de forma mais aprofundada como ocorre o processo de funcionamento. $\mathrm{O}$ airbag é um artefato tecnológico bastante abordado nas coleções, sendo explicado diversas vezes pelos livros de todas as coleções. Em 51, se explica o funcionamento das televisões antigas, com um texto e uma figura. Posteriormente se informa que as televisões antigas estão sendo substituídas por outros sistemas mais modernos, mas não há uma explicação de como funciona os sistemas mais modernos e nem uma comparação entre uma e outra. As televisões antigas, embora ainda bastante utilizadas em alguns locais, estão entrando em desuso por outras mais modernas. Dessa forma, o conhecimento científico e tecnológico que o aluno teve acesso nesse caso não serviu para explicar os artefatos tecnológicos mais modernos, apenas artefatos tecnológicos mais antigos que já estão em desuso. Neste ponto, acredita-se que com a ciência ensinada na escola, dificilmente seria possível explicar o funcionamento de um artefato tecnológico moderno. Isso ocorre porque a ciência ensinada na escola é bastante simplificada, sendo impossível compreender o funcionamento de um artefato tecnológico moderno com ela.

Em 52 se explica o funcionamento da máquina a vapor. Esse poderia ser um momento importante para se discutir sobre a questão tecnológica, pois a máquina a vapor foi de grande importância para a construção de nossa sociedade atual. Também é um importante exemplo de uma tecnologia que auxiliou no desenvolvimento da ciência, desmistificando a ideia comumente aceita de que a ciência sempre precede a tecnologia. Entretanto, o livro não aproveita esse exemplo para discutir essa questão nesse momento.

Em 53 é explicado o funcionamento do airbag em um box separado do texto, como mostra a figura 1. É explicado o funcionamento com a utilização de figura e texto e também é discutido como o airbag auxilia no cotidiano do aluno, permitindo maior segurança aos motoristas. Neste caso, o artefato tecnológico em questão também foi utilizado para introduzir um conceito, o de reações de oxirredução.

Resultados e Discussões 


\section{Açấo e cidadania}

Os airbags

Os airbags são mecanismos de segurança muito utilizados em veículos automotores. Assim como o cinto de segurança, os airbags frontais diminuem o movimento para frente do motorista durante uma colisão, reduzin do riscos de ferimentos na cabeça e no tórax causado quando a pessoa é lançada contra o volante e o painel do automóvel. Por essa razão, eles passam a ser iten obrigatórios em todos os veículos fabricados no Brasil partir de 2014.

Para que o mecanismo funcione, são necessários dois reagentes - a azida de sódio, $\mathrm{NaN}_{3}$, e o nitrato de potás sio, $\mathrm{KNO}_{3}$. Quando o veículo desacelera de forma brusca - como ocorre em um impacto - um dispositivo é acionado, e a azida de sódio se decompõe pelo efeito da temperatura.

$$
2 \mathrm{NaN}_{3}(\mathrm{~s}) \stackrel{\Delta}{\longrightarrow} \mathrm{Na}(\mathrm{s})+3 \mathrm{~N}_{2}(\mathrm{~g})
$$

O sódio metálico gerado, por ser muito reativo, entra em contato com o $\mathrm{KNO}_{3}$, formando mais nitrogênio molecular.

$10 \mathrm{Na}(\mathrm{s})+2 \mathrm{KNO}_{3}(\mathrm{~s}) \longrightarrow \mathrm{K}_{2} \mathrm{O}(\mathrm{s})+5 \mathrm{Na}_{2} \mathrm{O}(\mathrm{s})+\mathrm{N}_{2}(\mathrm{~g})$

0 nitrogênio é um gás inerte que infla a bolsa $(b a g)$, protegendo o motorista de um impacto muito danoso que lhe causaria lesões.

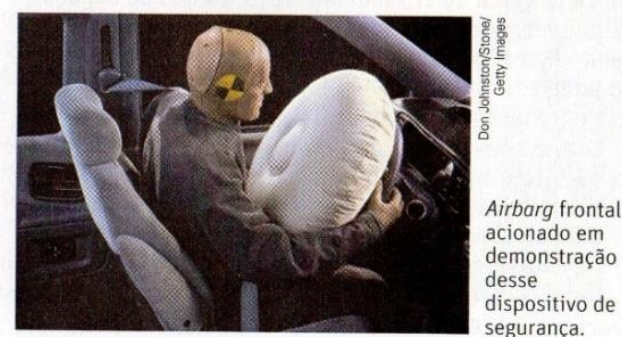

Figura 1 Exemplo (53) de explicação do funcionamento de um artefato tecnológico (C4, L1, p. 189)

Em outro exemplo da coleção 4 (figura 2), novamente é explicado o funcionamento do airbag, no livro 11 da coleção 4, possui um box explicando o funcionamento do airbag, com as reações envolvidas no processo.

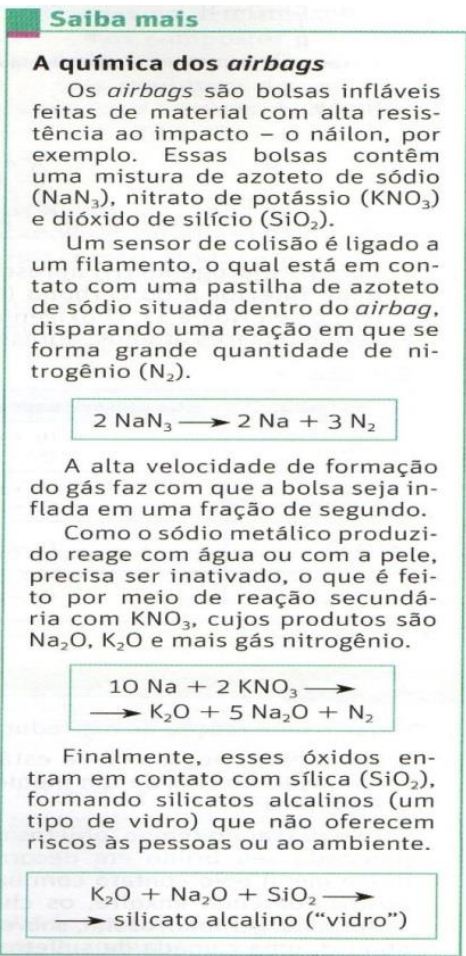

Figura 2: Exemplo (54) de explicação do funcionamento de um artefato tecnológico (C4, L2 p.208)

Ainda em outro exemplo da coleção 4, o livro explica o funcionamento do ônibus movido à hidrogênio, como podemos ver na figura 3 . 


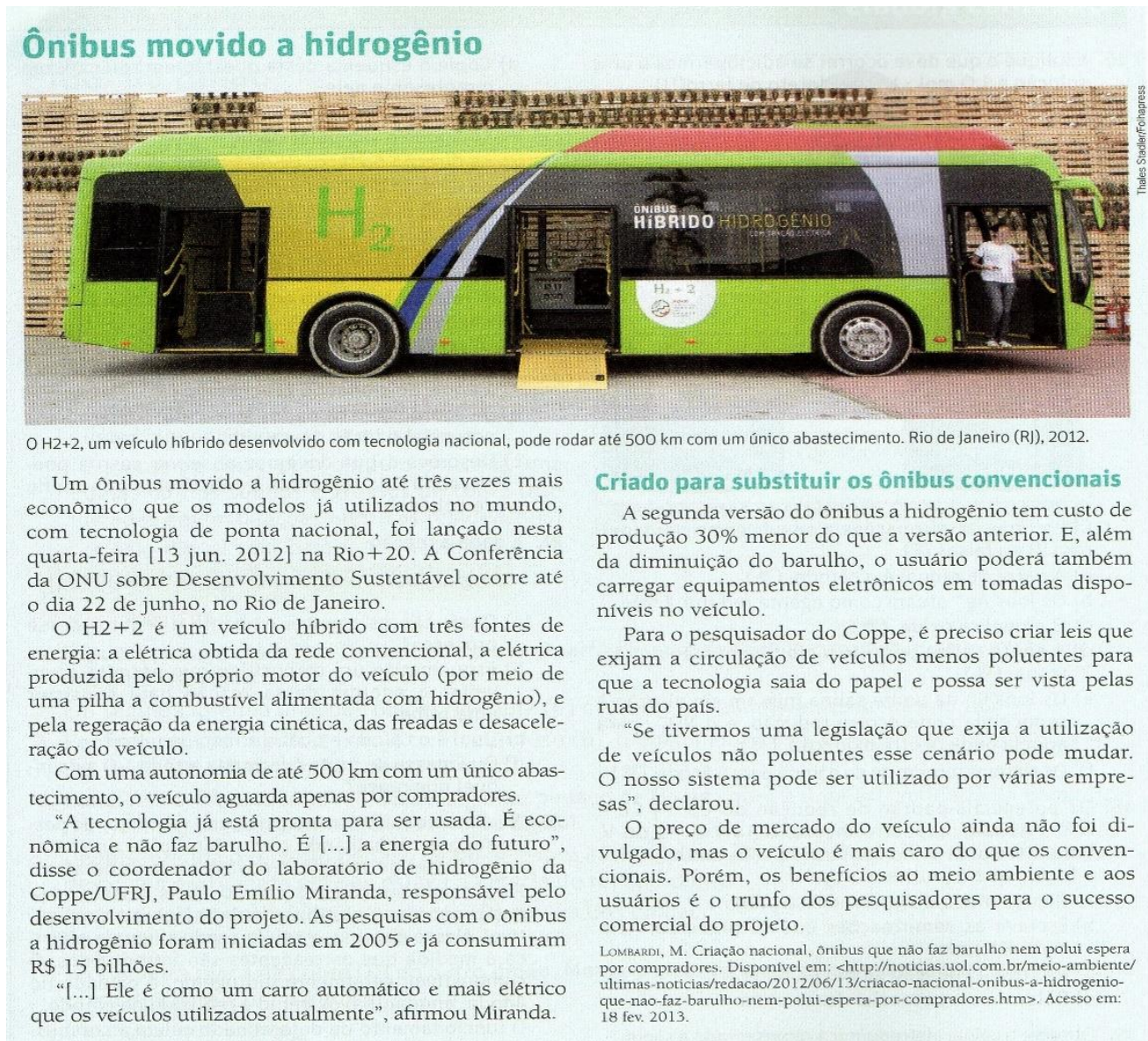

\section{Analise e discuta}

Para responder às questões abaixo, pesquise a respeito do assunto em jornais, revistas e na internet.

1. Responda:

a) O que são células a combustível? Faça um esquema simplificado de uma célula a combustível de hidrogênio e explique como funciona, apresentando as reações.

b) Qual é a semelhança e a diferença entre células a combustível e pilhas?

2. A Rio +20 foi uma conferência das Nações Unidas sobre desenvolvimento sustentável realizada no Rio de

Janeiro no mês de junho de 2012 e que reuniu quase todos os países do mundo com o intuito de discutir sobre a renovação do compromisso político com o desenvolvimento sustentável. O que é desenvolvimento sustentável? Você acha que é possível alcançar o desenvolvimento sustentável? Como?

Figura 3: Exemplo (55) de explicação do funcionamento de um artefato tecnológico

Nesses exemplos, o objetivo das coleções foi explicar o funcionamento de artefatos tecnológicos. São explicitados os produtos da tecnologia. A tecnologia como produto é apontada nos PCNEM como podemos ver abaixo, onde se diz que a tecnologia está integrada às Ciências Naturais uma vez que:

[...] uma compreensão contemporânea do universo físico, da vida planetária e da vida humana não pode prescindir do entendimento dos instrumentos pelos quais o ser humano maneja e investiga o mundo natural. Com isso se dá continuidade à compreensão do significado da tecnologia enquanto produto, num sentido amplo (BRASIL, 1999, p. 93). 
Podemos perceber nessa citação que o documento considera importante que o aluno compreenda sobre os produtos da tecnologia. Nessa visão, compreender o funcionamento de artefatos tecnológicos condiz com o que está sendo sugerido nos PCNEM.

Apesar de estar sugerido nos PCNEM, como foi possível perceber, os livros didáticos apresentam poucos exemplos em que realmente é explicado o funcionamento de um artefato tecnológico de maneira que possibilite ao aluno aprender realmente como esse artefato ou como o processo tecnológico funciona.

\subsection{Modelo linear de desenvolvimento científico e tecnológico}

Nesta categoria serão apresentados na tabela 8 exemplos em que aparece, de forma explícita, situações na qual a ciência auxiliou no desenvolvimento da tecnologia. Essa ideia já aparece em alguns exemplos anteriores, porém aqui serão mostrados alguns dos exemplos explícitos em que isso ocorre. Os exemplos levam a concepção de desenvolvimento linear de ciência e tecnologia, ou seja, é realizada uma descoberta científica e posteriormente ela é automaticamente ou de forma quase instantânea aplicada em algum processo tecnológico. Em muitos casos a ciência pode ser aplicada na tecnologia, entretanto esse processo não ocorre em todos os casos e não é instantâneo como os exemplos levam a pensar.

Os exemplos dessa categoria podem levar à falsa ideia de que a tecnologia é uma aplicação da ciência e que a ciência sempre antecede a tecnologia. $\mathrm{O}$ aluno pode ser induzido a pensar que primeiramente é descoberta uma lei ou teoria para posteriormente ela ser aplicada em um artefato tecnológico. Esse tipo de exemplo é bastante comum quando se aborda o conteúdo de modelo atômico e radioatividade.

Resultados e Discussões 
Tabela 8. Exemplos de modelo linear de desenvolvimento científico e tecnológico

(56) Os novos conhecimentos sobre a estrutura atômica têm possibilitado o desenvolvimento cada vez mais avançado de novas tecnologias que ampliam as possibilidades de ação humana. Isso exige mais responsabilidade dos químicos e compromisso da sociedade com os desafios para que este novo mundo seja melhor. (C2, L3, p. 284)
(59) No final do século XIX, os conhecimentos da Física clássica estavam bem estabelecidos. Avanços significativos em várias áreas - mecânica, termodinâmica, eletricidade e eletromagnetismo tinham possibilitado a compreensão de diversos fenômenos e o desenvolvimento de novas tecnologias. A invenção da máquina a vapor, a utilização da eletricidade nas indústrias e residências, a invenção de motores, o telégrafo, tudo isso estava contribuindo para mudar o modo de vida das pessoas. (C3, L1, p. 173)

(57) Conhecendo-se melhor a natureza do comportamento das subpartículas, uma infinidade de novas tecnologias poderá ser desenvolvida. (C2, L1, p. 194)

(58) A descoberta dessa radiação logo foi difundida e aplicada em diferentes situações. Esse é um bom exemplo de rápida aplicação tecnológica de descobertas científicas. Ela foi tão importante que, em apenas um ano após ser anunciada, os médicos já começaram, em todo o mundo, a utilizar os raios $\mathrm{X}$ para diagnósticos. (C2, L2, p. 271)
(62) Para isso foi necessário o desenvolvimento de modelos cada vez mais precisos, instrumentos e ferramentas matemáticas mais sofisticadas. Esses, por sua vez, possibilitaram o desenvolvimento de tecnologias mais avançadas que proporcionaram o avanço do conhecimento num ciclo que se retroalimenta. Todo esse conhecimento e tecnologia possibilitou uma compreensão maior da estrutura do átomo. $(\mathrm{C} 2$, L3, p. 287)

(63) Essa nova área da Química, conhecida como Química Quântica ou Química Teórica é um promissor campo de pesquisa e tem possibilitado o desenvolvimento de importantes tecnologias. (C2, L3, p. 308)

(64) Esse modelo foi responsável por inúmeros avanços tecnológicos no século passado. Conhecer algo sobre ele permite a você, como cidadão do século XXI, saber como o nosso olhar sobre a matéria é bastante diferente da visão clássica de quase cem anos atrás, que, apesar de ter sido a base de toda a Química do Ensino Médio estudada até aqui, não é suficiente para explicar tudo. (C2, L3, p. 295)

$\mathrm{Na}$ próxima categoria, apresentaremos alguns exemplos históricos que desmentem essa ideia. Essa ideia também pode levar a acreditar que a tecnologia se desenvolve automaticamente a partir da ciência de base. Portanto basta um governo investir em ciência que teremos produção tecnológica, o que também não ocorre. Um exemplo disso é o Japão, um país com alta tecnologia e escassas pesquisas em ciência de base.

\subsubsection{Ciência como derivada da tecnologia}


Nesta categoria serão apresentados exemplos contrários aos anteriores, trazendo situações em que a tecnologia auxiliou no desenvolvimento da ciência. As situações apresentadas mostram que o desenvolvimento tecnológico é capaz de auxiliar no desenvolvimento científico, derrubando a ideia da tecnologia como ciência aplicada. Silva (2003) cita o exemplo da luneta construída por Galileu. Galileu trouxe diversas contribuições para a astronomia por meio do uso da luneta, entretanto ele não conseguia explicar o funcionamento da mesma por meio de teorias científicas. Esse é um exemplo de uma tecnologia que impulsionou o desenvolvimento da ciência.

Acevedo et al. (2003) também citam alguns exemplos de momentos históricos em que a ciência derivou da tecnologia. Conceitos e teorias da termodinâmica se desenvolveram a partir de reflexões teóricas sobre a máquina a vapor e a química orgânica industrial cresceu potencialmente por interesse de fabricantes de tintas. Porém, historicamente temos casos em que a ciência contribuiu para o desenvolvimento da tecnologia, outros casos em que ambas se desenvolveram paralelamente e casos em que ambas se desenvolveram de forma independente.

Os exemplos abaixo (tabela 9) mostram situações em que uma tecnologia precedeu o desenvolvimento científico. Os exemplos podem ser importantes para desmistificar a ideia de que a ciência sempre precede a tecnologia, mas também podem levar a ideia de que a tecnologia sempre precede a ciência. Segundo Acevedo et al. (2003) essa ideia supõe que a tecnologia é anterior à ciência e está relacionada ao pensamento marxista. Afirmam que a ciência não é mais que uma forma intensificada de tecnologia, ou seja, a ciência se move por interesses tecnológicos. Segundo essa ideia a sociedade de uma forma geral se move por interesses tecnológicos, relacionados a questão de mercado.

Porém, a quantidade de exemplos contrários em que a tecnologia é vista como uma aplicação da ciência é bem maior que os exemplos dessa categoria, acredita-se que os exemplos encaixados nessa categoria sejam de grande importância para levar o aluno a refletir que a tecnologia também pode auxiliar no desenvolvimento científico. Segundo Acevedo et al. (2003) a maioria dos alunos compreendem a influência que a ciência possui na tecnologia, porém eles não percebem a influência da tecnologia sobre a ciência, isso porque a ideia mais difundida é da tecnologia como ciência aplicada. Esse tipo de exemplo pode auxiliar os alunos a compreender essa relação. 
Tabela 9. Ciência como derivada da tecnologia

(65) Por sua vez, o aperfeiçoamento tecnológico contribui para o desenvolvimento da Ciência. Cálculos que os cientistas, às vezes, levavam dias para realizar, atualmente, graças aos computadores, são feitos em alguns minutos. Esses mesmos computadores permitem que os químicos da atualidade projetem e modelem materiais pulando diversas etapas antes feitas em bancadas de laboratórios. (C2, L1, p. 17)

(66) Por isso, a Meteorologia não emergiu realmente como ciência antes do século XVII, quando foram inventados o barômetro, que mede confiavelmente a pressão do ar, e um termômetro preciso para medir temperaturas. (C1, L2, p. 12)

(67) Apenas na década de 1980 foi desenvolvida uma tecnologia que permite "ver" os átomos de um material. A microscopia de tunelamento fornece imagens de átomos isolados e planos inteiros de átomos na superfície de um material. (C3, L1, p. 153)

(68) Cromatógrafos, espectrômetros de massa e espectrofotômetros são instrumentos utilizados pelos cientistas e por grandes indústrias para identificar materiais e realizar testes de controle de qualidade de produtos. Esses aparelhos são acoplados a computadores que identificam os sinais produzidos e fornecem ao analista a informação necessária para interpretar os resultados. (C4, L3, p. 14)
(69) No século XVIII, o engenheiro e mecânico James Watt [1736-1819] construiu a primeira máquina a vapor, grande alavanca para a Revolução Industrial. A busca do aumento da eficiência das máquinas a vapor levou ao surgimento da Termodinâmica e da Termoquímica. (C2, L2, p. 189)

(70) Os modelos obtidos com o apoio da tecnologia computacional são largamente utilizados na Química Teórica, cujo objetivo é descrever com mais precisão a constituição da matéria.. (C2, L1, p. 98)

(71) A ciência do século $\mathrm{XX}$ tornou a realidade atômica observável. Várias tecnologias foram desenvolvidas para possibilitar essa observação. Métodos como a difração de raios X permitem determinar a posição e a distância entre as partículas num arranjo cristalino. (C3, L1, p. 153)

(72) Muitas substâncias que hoje são consideradas compostos eram entendidas como elementos químicos, pois a tecnologia então conhecida não permitia sua decomposição. É o caso, por exemplo, da alumina e da potassa, ambas classificadas como elemento por Dalton. (C4, L1, p.85)

Em outro exemplo, é abordada uma situação em que uma tecnologia ajudou a desenvolver a ciência e posteriormente a ciência ajudou a desenvolver a tecnologia, em um ciclo de dependência entre ambas. Esse exemplo pode ser muito importante para o aluno compreender as relações de interdependência da ciência e da tecnologia.

(73) O estudo das partículas elementares constituintes do núcleo atômico começou com o primeiro acelerador de partículas desenvolvido em 1929 pelos físicos ingleses John Douglas Cockcroft (1897-1967) e Ernest Thomas Sinton Walton (1903-1995) na Universidade de Cambridge, Inglaterra. Utilizando esse aparelho Cockcroft e Walton realizaram a primeira reação nuclear induzida artificialmente. O desenvolvimento de aceleradores de partículas cada vez maiores e mais potentes possibilitou um grande avanço tecnológico em diversas áreas do conhecimento, como na pesquisa em Física básica e aplicada, que permitiu conhecer melhor a estrutura da matéria e a origem do Universo. Essa tecnologia é utilizada na Medicina, em aparelhos de raios $\mathrm{X}$ e na obtenção de isótopos radioativos para tratamentos de tumores específicos, na indústria farmacêutica para esterilização de materiais, na indústria química para polimerização de plásticos, e na indústria de eletrônicos no processo de miniaturização de circuitos (C1, L3, p. 306). 


\subsubsection{Tecnologia ou Técnica}

Aqui serão apresentados exemplos em que a tecnologia é vista como sinônimo de técnica ou seus conceitos parecem se confundir. Nos trechos abaixo, os autores chamam algumas atividades técnicas pelo nome de tecnologia, ocorrendo uma confusão entre os conceitos. Segundo Silva (2003), na linguagem cotidiana as palavras tecnologia e técnica se confundem, sendo relacionadas a fazer algo. $\mathrm{O}$ uso diário das duas palavras pode levar à falsa ideia de que todos conhecem seu significado. Tanto o termo tecnologia quanto o termo técnica derivam da palavra grega techné que significa a capacidade de produzir um objeto. Devido à essa origem semelhante, podemos ter a falsa ideia de que ambas possuem o mesmo significado. Segundo Bunge (1985), tecnologia e técnica são coisas diferentes. Bunge (1985) define técnica como o controle ou transformação da natureza pelo homem, por meio de conhecimentos pré-científicos. Já a tecnologia utilizaria conhecimentos científicos, embora não se resuma a eles. Baseado nessa definição, atividades como a utilização de ferramentas não podem ser consideradas uma tecnologia, pois não utilizam conhecimentos científicos. Neste trabalho, utilizaremos as ideias de Bunge (1985) em relação à tecnologia e técnica.

Bunge (1980) aborda que tecnologia seria a técnica que utiliza conhecimentos científicos. É citado como exemplo de distinção entre tecnologia e técnica, a técnica da costureira e a tecnologia da indústria da confecção.

Segundo Veraszto et al. (2008), a técnica é um conjunto de conhecimentos práticos, desenvolvidos pelo ser humano para melhorar sua maneira de viver. Com o desenvolvimento da sociedade ocidental, chegou um momento em que a dimensão prática começou a querer saber o porquê. Assim, com a união da parte prática e da parte lógica, surgiu a tecnologia.

Nas ideias dos autores acima, podemos perceber que a tecnologia é concebida como algo recente. Nessas visões, atividades como o uso de ferramentas e cozer alimentos não podem ser consideradas tecnologias. Aqui veremos exemplos dos livros em que essas atividades técnicas são chamadas de tecnologia. Nos exemplos da tabela 10 se fala sobre o domínio do fogo e que isso propiciou desenvolvimento tecnológico. A manipulação de metais também é vista como um desenvolvimento tecnológico, como em 76. Como tecnologias, os livros citam cozimento de alimentos, manipulação e extração de metais. Em exemplos como 75 , atividades como cozer alimentos também são consideradas tecnologias. 
Tabela 10. Tecnologia ou técnica

(74) O domínio do fogo propiciou o desenvolvimento de algumas tecnologias e contribuiu para que o ser humano pudesse se fixar a terra. $(\mathrm{C} 2$, L2, p. 188)
(76) A metalurgia do ferro iniciou-se por volta de 1300 a.C. com os hititas, mas só teve grande difusão no primeiro milênio a.C., devido ao seu largo emprego na fabricação de armas. O domínio de tais tecnologias alterou os rumos da história. Usando espadas de aço, os romanos obtiveram importantes vitórias em sua guerra contra os gauleses, que usavam espadas de ferro, menos resistentes. (C2, L3, p. 211)

(75) Fissão quer dizer quebra, divisão. Diferentemente do que imaginava Dalton, isso também pode ser feito com átomos. A fissão nuclear, assim como o fogo, ocorre espontaneamente na natureza. $\mathrm{O}$ controle do fogo permitiu à humanidade um maior controle da natureza e o desenvolvimento de tecnologias, como cozer alimentos, produzir e manipular diferentes metais. Ao aprender a controlar a fissão nuclear, a humanidade possibilitou outro salto, permitindo a geração de energia em larga escala e a produção de armas de potência nunca antes imaginadas e de diversas tecnologias. (C2, L2, p. 295)
(77) Os processos químicos, nos quais substâncias se transformam em outras, sempre fascinaram a humanidade. Na busca de dominá-los, desde os primórdios da humanidade, uma série de tecnologias químicas foi desenvolvida: o controle da combustão, a obtenção de metais com base nas transformações químicas de seus minérios, o cozimento de alimentos, o processo de curtição do couro, a fabricação de vidros e cerâmicas, a obtenção de drogas e medicamentos etc. O domínio dessas tecnologias possibilitou maiores intervenções no ambiente e humano. (C2, L1, p.74) contribuiu para melhorar as condições de vida do ser

A utilização de ferramentas também é visto como uma tecnologia e nessa citação se considera o "nascimento" da tecnologia.

(78) Da mesma maneira que podemos dizer que a Química começou a se desenvolver a partir de técnicas primitivas de domínio do fogo, é possível considerar que a tecnologia nasceu quando o ser humano descobriu que podia fazer ferramentas a partir de diferentes materiais, tais como paus, ossos e pedras $(\mathrm{C} 2, \mathrm{~L} 1, \mathrm{p} .16)$.

Aqui também se considera o alto-forno, uma técnica bem antiga, como sendo uma tecnologia.

(79) Alto-forno - Apesar dessa tecnologia já ser usada desde 1200 a.C., no século XIV aumenta a utilização do carvão vegetal como fonte de energia, por causa de sua maior eficiência na combustão. Isso ampliou em muito a sua utilização na fundição de metais e na construção de diferentes utensílios, pela possibilidade de se alcançar temperaturas mais altas (C2, L2, p. 189).

Em outro exemplo, o estilingue que também é algo bastante antigo, é visto como um artefato tecnológico. O livro também discute a responsabilidade da utilização dos artefatos tecnológicos. 
(80) No estilingue, a força utilizada para esticar o elástico é transferida para a pedra que é arremessada. Por isso, esse antigo brinquedo, conhecido também por atiradeira, bodoque, baladeira e cetra, é tão difundido no Brasil e no mundo. $\mathrm{O}$ problema é quando essa força é transferida para acertar animais, pessoas, vidraças. Lembre-se: todo artefato tecnológico tem que ser usado apropriadamente (C2, L3, p. 145).

Os exemplos acima mostram algumas atividades, que, baseado em Bunge (1985), não podem ser consideradas tecnologias e sim atividades técnicas. Como já visto anteriormente sobre as ideias do autor, para Bunge (1985), técnica e tecnologia possuem objetivos precisos, que é a produção de artefatos. Para isso, tanto a técnica como a tecnologia produzem conhecimentos próprios. Alguns dos conhecimentos utilizados pela técnica e pela tecnologia já existem e outros novos conhecimentos são produzidos. A técnica utiliza conhecimentos do saber vulgar tradicional, conhecimentos pré-científicos, de senso comum e empíricos. A tecnologia utiliza de conhecimentos científicos e conhecimentos tecnológicos novos. O artefato produzido pela técnica e pela tecnologia não precisa ser um objeto, pode ser algo social, como já exposto anteriormente. Técnica e tecnologia, na visão de Bunge (1985), possuem valores próprios, regras e normas próprias de produção. Assim, a técnica acompanhou o desenvolvimento da humanidade e a tecnologia impulsionou ainda mais esse desenvolvimento nos últimos tempos.

Em outro caso o livro também utiliza de forma inapropriada a palavra tecnologia, porém dessa vez o livro a utiliza entre aspas, por não considerá-la a palavra que mais se encaixa no caso.

(81) Não é só o ser humano que tem “tecnologia" para produzir polímeros. A seda é um polímero produzido pelo bicho-da-seda e utilizado pela humanidade há séculos (C2, L3, p.163).

\subsubsection{Discussão do significado da tecnologia}

Foram procurados exemplos dos livros didáticos em que ele apresentasse uma discussão sobre o significado da tecnologia. Apenas a coleção 2 apresentou esse tipo de discussão e conceitua tecnologia como:

(82) o conceito de tecnologia está associado ao conhecimento especializado para produzir e aprimorar bens de consumo (alimentos, roupas, cadeiras, televisores etc.), mercadorias (produtos químicos, ferramentas, máquinas etc.) e serviços (tratamento odontológico, construção civil etc.), geralmente em processos industriais que envolvem máquinas e grandes organizações $(\mathrm{C} 2, \mathrm{~L} 1, \mathrm{p} .16)$. 
A coleção também discute a origem da tecnologia no seguinte trecho:

(83) Essa tecnologia moderna teve desenvolvimento acelerado após a Revolução Industrial, por causa da introdução de novos modelos de produção e de exploração da natureza. Esses modelos foram, pouco a pouco, substituindo o trabalho dos artesãos. A troca gradativa do trabalho humano pela máquina reduziu custos e aumentou a produção. Esperava-se que a industrialização diminuísse o tempo de trabalho humano, liberando as pessoas para desenvolver mais atividades culturais $\mathrm{e}$ de lazer (C2, L1, p.16).

Podemos perceber através das citações que a coleção considera como tecnologia apenas o conhecimento desenvolvido após a Revolução Industrial, o que vai de encontro aos demais exemplos dos livros da coleção que consideravam atividades como cozer alimentos e manipular metais uma tecnologia, como foi possível ver na categoria anterior.

\subsubsection{CULTURA TECNOLÓGICA}

O conceito de cultura tecnológica utilizado aqui foi apresentado anteriormente por Quintanilla et al. (2011), onde cultura tecnológica é vista como o conjunto de informações relacionadas à tecnologia, ao funcionamento de artefatos e à produção tecnológica. Quintanilla et al. (2011) analisaram a presença da cultura científica e tecnológica em livros utilizados em ESO (ensino secundário obrigatório - estudantes entre 12 e 16 anos) na Espanha. Os autores constataram que os livros possuem alguns exemplos de cultura tecnológica, como informações sobre as tecnologias, suas regras de operação e seus valores. Essas informações estão mais presentes em livros de tecnologia. Os livros também possuem informações como representações sociais e avaliações do uso da tecnologia. Essas informações estão mais presentes em livros de ciências sociais. Agora analisaremos se nos livros didáticos de química brasileiros também possuem exemplos de cultura tecnológica.

\subsubsection{Cultura Tecnológica Intrínseca}

Neste tópico serão apresentados alguns exemplos referentes à cultura tecnológica intrínseca, ligados aos aspectos internos dos sistemas tecnológicos (tabela 11). Nos exemplos abaixo, 159, 160 e 161, podemos perceber a questão da importância das patentes. 
Tabela 11 Exemplos de importância de patentes

(84) Hall ligou a bateria, de modo que a corrente elétrica atravessasse a mistura, e observou o alumínio metálico se acumulando ao redor do eletrodo negativo da bateria. Tão logo o metal esfriou o suficiente para poder ser segurado nas mãos, Hall correu para mostrá-lo ao professor Jewett. Consta que, poucos meses depois, um jovem francês chamado Paul L. T. Heroult (1863-1914), também com 22 anos, desenvolveu o mesmo processo eletrolítico para a obtenção de alumínio (sem nunca ter ouvido falar do trabalho de Hall). De qualquer forma, Hall entrou primeiro com o pedido de patente do processo e recebeu a prioridade. Hall ficou milionário com sua descoberta e, ao morrer, deixou grande parte de sua fortuna para o Oberlin College. (C1, L2, p. 294)

(85) Em parte, são as vibrações moleculares da água que tornaram a larga aplicação na cozinha dos fornos de micro-ondas. Esse forno foi patenteado em 1953 e, a partir da década de 1970, ganhou grande popularidade. Hoje, está presente em muitas residências e estabelecimentos comerciais. (C2, L2, p. 112)

(86) Depois de muitas tentativas [...] ele acidentalmente deixou que uma mistura de borracha e enxofre tocasse um fogão quente. Para sua surpresa, a borracha não derreteu, mas apenas queimou um pouco, como faria um pedaço de couro. Goodyear percebeu imediatamente a importância desse acidente. [...] Goodyear determinou a temperatura ideal e o tempo de aquecimento para estabilizar a borracha. Deu entrada ao patenteamento, [...] processo que ele denominou vulcanização [...]. Goodyear não viveu de maneira feliz mesmo depois de sua descoberta do processo de vulcanização. Ficou envolvido na defesa de sua patente e nunca se recuperou dos grandes débitos que contraíra antes de morrer em 1860. (C4, L3, p. 246)

Em 84 se discute um caso em que ocorreu a disputa de uma patente e também são relacionados os aspectos econômicos envolvidos nos processos tecnológicos. Também ocorre uma breve explicação do processo tecnológico em questão. Em 85 fala-se sobre o microondas, um importante artefato tecnológico da atualidade, fala-se sobre a sua popularidade e o ano em que foi registrada a patente. Em 86 também se aborda a questão da patente e nesse caso se apresenta um pouco da história de vida de Goodyear.

Em outros exemplos fica explícito que não basta um produto ser eficiente e útil para a população, é necessário ter importância econômica e fins comerciais para ser fabricado (tabela 12). Como a tecnologia está ligada com grandes empresas, os fins comerciais têm grande influência no seu desenvolvimento. Esse exemplo pode servir como um questionamento e reflexão em relação à nossa sociedade capitalista em que o desenvolvimento tecnológico está ligado com a questão do lucro.

Tabela 12 Exemplos de questões de mercado

(87) A primeira versão das latas autoaquecidas foi utilizada pelo exército britânico na Segunda Guerra Mundial. Outras vieram depois, mas não tiveram sucesso. Também há várias patentes e tecnologias desenvolvidas para resfriar o conteúdo das latas, nenhuma disponível no mercado até o momento. (C1, L2, p. 149)

(88) Os resultados econômicos obtidos com o desenvolvimento dos insumos agrícolas têm sido muito grandes, o que tem contribuído para o abastecimento de alimentos em todo o planeta. O mercado desses produtos químicos é enorme. Por isso, os interesses econômicos para que o seu emprego na lavoura não seja substituído por outras tecnologias menos agressivas são grandes e fortes. (C2, L1, p. 221)

(89) Mesmo assim, a controvérsia em torno do tema continua, pois muitos avaliam que as demais tecnologias não seriam capazes de suprir a necessidade de alimentos. Mas, sem dúvida nenhuma, a redução do uso de agrotóxicos faria com que muitos problemas ambientais diminuíssem, contribuindo para que esses produtos defendessem a lavoura agredindo o menos possível o ambiente. (C2, L1, p. 221) 
Em 87 é abordada a questão das latas autoaquecidas, que mesmo já sendo uma tecnologia desenvolvida, ainda não está disponível no mercado por questão de lucro. Isso mostra que não basta uma tecnologia ser útil à população, mas ela precisa atender às questões de mercado e gerar lucro. Em 88 aparece uma dura realidade do mercado capitalista, em que mesmo se uma tecnologia gerar impacto ambiental ela continua sendo utilizada por interesses econômicos. Em 89 essa relação volta a aparecer, onde interesses econômicos envolvidos nos processos tecnológicos se sobrepõem a interesses ambientais e sociais. Nos trechos, é possível perceber a relação do progresso tecnológico com os lucros, deixando-se de priorizar a questão ambiental. O extrato busca levar o leitor a uma reflexão em relação à degradação ambiental e ao progresso humano, levando à ideia de que o progresso tecnológico é um vilão e culpado por diversos problemas relacionados à sociedade atual. A ideia exposta é de que a tecnologia busca o lucro.

Em 90 são mostradas situações diferentes em que se busca desenvolver uma tecnologia mais barata e que seja mais acessível à população:

(90) Para que os nanotubos cheguem a se incorporar a materiais de uso comum, há um obstáculo a ser vencido: desenvolver uma tecnologia barata e confiável para produzir o material em quantidade e, segundo especificações pré-determinadas requisitos imprescindíveis para seu uso industrial. Os processos conhecidos de síntese dessas estruturas não dão conta de uma produção em larga escala (C1, L1, p. 207).

Nos exemplos, é possível perceber a relação da tecnologia com a busca de produtos mais baratos para a sociedade, que podem ser produzidos em larga escala e atingir um número cada vez maior de pessoas. O caso aqui pode estar relacionado também com lucros, pois quanto mais pessoas puderem utilizar determinada tecnologia, mais lucro as empresas terão.

Em outros exemplos apresentados na tabela 13, também é exposto a questão econômica envolvida na tecnologia, neste caso não relacionado aos lucros, que ela visa como nos exemplos anteriores, mas sim ao dinheiro necessário para produzir determinada tecnologia. 
Tabela 13 Exemplos de questões de mercado

(91) O petróleo do pré-sal está localizado nos oceanos, numa profundidade de cerca de $6000 \mathrm{~m}$, depois de uma camada de deposição de rochas sedimentares geologicamente formada ao longo do tempo, como descreve a figura. Para retirá-lo é necessário alta tecnologia e grandes investimentos. $\mathrm{O}$ debate atual sobre a exploração desse petróleo não envolve somente questões técnicas, mas também econômicas, políticas e ambientais. (C2, L2, p. 192)

(92) Ainda existem alguns problemas a serem resolvidos quanto ao funcionamento das células de combustível: alto custo de manutenção e baixa longevidade. O primeiro tende a ser resolvido com a difusão e consequentente barateamento da tecnologia. Quanto à vida útil da bateria, essa é uma questão para a qual tem sido feitos grandes investimentos na busca de soluções economicamente viáveis. Isso certamente irá favorecer a diminuição do custo final por quilômetro rodado. (C2, L3, p. 266)

(93) Ainda são levados em conta na instalação de indústrias os aspectos tecnológicos. Toda indústria deve desenvolver novos processos tecnológicos ou pagar pelo licenciamento para utilizar processos já patenteados. Por isso, a expansão de complexos industriais no país depende essencialmente de investimentos em ciência e tecnologia que garantam o desenvolvimento de novos processos em um modelo que preserve os interesses nacionais e, sobretudo, o ambiente. (C2, L3, p. 182)

Os exemplos da tabela 13 mostram que para o desenvolvimento de novas tecnologias é necessário investimento em pesquisas. A tecnologia envolve questões econômicas que precisam ser discutidas em sala de aula para uma formação cidadã do aluno. Os exemplos presentes no livro são de grande importância para que isso ocorra.

O exemplo 94 mostra que a tecnologia atende às demandas da sociedade. Quando a sociedade necessita de um artefato tecnológico específico ou de uma tecnologia, os pesquisadores buscam novos processos para atender essa demanda.

(94) No século XX, o crescimento populacional foi explosivo, proporcional aos avanços tecnológicos que permitiram a irrigação, a mecanização da agricultura, a utilização de fertilizantes e pesticidas químicos. A demanda pelo aumento da produtividade agrícola implicou o desenvolvimento de novas tecnologias. A nova ordem se fez e os sistemas de produção foram modificados. As lavouras foram mecanizadas e os insumos agrícolas, usados com mais frequência. Esse desenvolvimento, que colocou mais comida na mesa das pessoas, teve contribuição significativa da Química. (C2, L1, p. 185)

Esses trechos mostram que a tecnologia não pode ser vista de forma desvinculada da sociedade, pois ela está interligada a aspectos econômicos e sociais.

Na tabela 14 são apresentados outros exemplos presentes nos livros abordando sobre a questão das dificuldades técnicas e desafios enfrentados por engenheiros para a produção de uma nova tecnologia. 
Tabela 14 Exemplos de desafios enfrentados na tecnologia

(95) A preocupação maior, do ponto de vista tecnológico, não é a profundidade e sim a camada de sal. O Brasil é um dos líderes mundiais em exploração de petróleo em águas profundas, mas nunca teve de atravessar uma camada desse tipo. "Vamos ter de desenvolver essa tecnologia", disse o engenheiro Nelson Ebecken, coordenador do Núcleo de Transferência de Tecnologia (NTT) da Coordenação dos Programas de Pósgraduação de Engenharia (Coppe) da Universidade Federal do Rio de Janeiro (UFRJ), principal parceira acadêmica da Petrobras. "Se essa camada de sal estivesse em terra já seria difícil. Imagine, então, a três mil ou quatro mil metros [de profundidade]. (C1, L3, p. 18 e 19)

(96) Dado o elevado consumo do petróleo, o domínio de sua exploração tem sido fator de desenvolvimento das nações. Nesse processo, o Brasil tem enfrentado o desafio tecnológico na identificação de reservas petrolíferas e no processo de sua extração desenvolvendo técnicas sofisticadas de prospecção em grandes profundidades marítimas. (C2, L2, p. 191)

Nos extratos da tabela 14 podemos identificar as dificuldades técnicas ao desenvolver um processo tecnológico e as preocupações dos técnicos e engenheiros envolvidos no processo. É mostrada também a preocupação em desenvolver novas técnicas e conhecimentos para realizar algum processo.

Ainda em outros exemplos são mostradas outras características dos sistemas tecnológicos, algumas preocupações que se deve ter ao trabalhar com determinados materiais:

(97) O uso de equipamentos que contém fontes radioativas deve atender a uma extensa série de exigências quanto à segurança e à radioproteção. Desde a autorização para compra da fonte radioativa, o órgão regulatório, a CNEN, exige que a empresa possua instalações, equipamentos de segurança, procedimentos e pessoal treinado em número e condições adequadas para a atividade envolvida, e esses controles são acompanhados durante todo o tempo em que a empresa tem autorização para desenvolver sua atividade. (C1, L3, p. 290)

Em 97 é mostrado algumas questões de regras e cuidados envolvidos nos processos tecnológicos, visando à questão de segurança. Os técnicos sempre devem estar atentos a algumas especificações para a segurança. Demais processos tecnológicos também podem envolver regras, mesmo que não utilizem materiais radioativos como nos casos anteriores. Muitas vezes, as regras envolvem questões de segurança e cuidado com determinados materiais ou processos. Também podem existir leis específicas para regulamentar os processos tecnológicos, como mostram os exemplos apresentados na tabela 15. 
Tabela 15 Exemplos de regras da tecnologia

(98) É com base nessa identificação que se estabelecem leis como as do Conselho Nacional do Meio Ambiente (Conama). Uma dessas leis institui que baterias industriais constituídas de chumbo, cádmio e seus compostos, destinados a telecomunicações, usinas elétricas, sistemas ininterruptos de fornecimento de energia, alarme, segurança, movimentação de cargas ou pessoas, partida de motores diesel e uso geral industrial, após seu esgotamento energético, deverão ser entregues pelo usuário ao fabricante ou ao importador ou ao distribuidor da bateria, as recolher e dar destino às pilhas depois de usadas. Os legisladores puderam criar essa lei com base no momento em que os químicos identificaram os efeitos ambientais provocados pela quantidade de metal pesado existente em tais baterias. (C2, L1, p. 39 e p.40)

(99) No Brasil, o controle legal da engenharia genética está previsto por legislação específica, que, em função dos aspectos éticos a ela vinculados, tem sido objeto de muita divergência. No centro da polêmica está o questionamento sobre os riscos elevados a que estamos sujeitos, em relação à nossa saúde e ao ambiente, com a introdução dessa tecnologia. (C2, L3, p. 11)

(100) A implantação dos conversores catalíticos nos automóveis que circulam nas cidades brasileiras é objeto de legislação específica, que exigiu que as indústrias passassem a fabricar automóveis com catalisadores a partir de 1994, e que até 1996 todos os automóveis novos deveriam sair de fábrica com esse equipamento. (C3, L2, p. 156)

Nos exemplos da tabela 15 são mostradas situações em que foram criadas leis específicas para controlar os sistemas tecnológicos. É necessário que a população tenha conhecimento dessas leis e participe ativamente dessas decisões, não ficando restrita apenas a poucos envolvidos nos processos. A população precisa participar dessas decisões, pois são coisas que afetam diretamente a sociedade. Em 98 e 100 a sociedade é afetada, pois a contaminação causada por pilhas e a poluição dos automóveis pode vir a afetar diretamente a saúde da população e nossos recursos naturais. Em 99 a questão da engenharia genética é algo bem polêmico, pois ao mesmo tempo em que pode trazer uma série de avanços para a questão da saúde, também pode trazer riscos à população. É necessário que os futuros cidadãos sejam instruídos para discutir esse tipo de problemática com argumentos para tomar decisões. Segundo Feenberg (2010), a tecnologia deve ser abarcada pela democracia, a tecnologia deve ser controlada pela sociedade em geral e não apenas por especialistas da área.

Em 101, é mostrado que os pesquisadores organizam simpósios e eventos para discutir questões envolvidas no processo tecnológico, bem como compartilhar seus estudos.

(101) O número de pesquisadores interessados em desenvolver conhecimento e tecnologia na área cresceu e esses passaram a organizar simpósios e congressos sobre o assunto. As descobertas geraram tecnologias que foram incorporadas por indústrias, levando ao surgimento de fábricas especializadas na produção de catalisadores. (C2, L2, p. 258)

Os pesquisadores também buscam aperfeiçoar tecnologias existentes, tornando-as mais simples e práticas, como é mostrado no exemplo 102: 
(102) Os primeiros computadores chegavam a ocupar uma sala inteira. O desenvolvimento dos chips, minúsculos circuitos eletrônicos que substituíram as válvulas, possibilitou a redução contínua do tamanho dos computadores, apesar do aumento da capacidade de processamento. (C2, L1, p.17)

As decisões relacionadas à tecnologia são apresentadas como restritas aos pesquisadores, técnicos e engenheiros. A população ficaria à margem dessas decisões, como é mostrado no fragmento 103:

(103) A disponibilidade de reservas de combustível é um fator importante na decisão sobre a opção tecnológica, mas o seu uso como fonte depende dessa decisão. $\mathrm{O}$ desenvolvimento de sistemas para exploração, transporte, armazenamento e distribuição dos derivados de petróleo foram muito mais atrativos do que o desenvolvimento tecnológico de sistemas para o uso do gás natural. Essa opção feita pelos técnicos e investidores fez com que hoje uma grande quantidade de gases presentes em reservas de petróleo não seja aproveitada. (C2, L2, p. 302)

A tomada de decisões para esses assuntos deve ser algo que envolva a população. Para isso a população deve ser instruída a participar ativamente das decisões. Muitas vezes essas decisões não são simples e envolvem uma série de fatores que dificultam a participação ativa de todos.

(104) A escolha de fontes de energia a serem utilizadas é uma decisão estratégica e deve considerar diversos aspectos: tecnologia disponível, custo financeiro, custo social, autonomia para geração, impactos ambientais etc. Essa decisão não é tão simples e depende da combinação de diversas variáveis: custo, disponibilidade do recurso, quantidade de poluentes gerada, entre outras. (C2, L2, p. 301)

\subsubsection{Cultura Tecnológica Extrínseca}

Nesta categoria serão apresentados exemplos dos livros de como a tecnologia é exposta e, assim, trata da imagem de tecnologia que está sendo vinculada nos livros didáticos.

\subsection{Pessimismo Tecnológico}

Aqui serão apresentados exemplos em que a tecnologia é vista como algo ruim, a causa de problemas ambientais e desigualdades sociais. A tecnologia seria vista como responsável pela destruição do planeta e pela pobreza. Esses exemplos podem levar o aluno a ter uma imagem negativa da tecnologia, mas também podem levá-lo a refletir mais sobre a degradação do meio ambiente e o consumismo. Esses exemplos são de fundamental 
importância, visto que pesquisas mostram que os alunos e professores têm uma visão de que a tecnologia é sempre benéfica, como mostra Auler e Delizoicov (2001), Kist e Ferraz (2010) e Barros Filho et al. (2009). A ideia de pessimismo tecnológico pode desmitificar a falsa ideia de que a tecnologia é sempre benéfica.

Os exemplos apresentados na tabela 16 mostram situações em que a tecnologia ou artefatos tecnológicos são colocados como culpados pelas destruições ambientais, poluição, efeito estufa, aquecimento global, entre outros problemas enfrentados atualmente. São relacionados os impactos ambientais com as indústrias e usinas. Esses exemplos podem levar a reflexões importantes e repensar a questão ambiental, levando a mobilizações e pressionar as indústrias e o governo para investimento em energias limpas e que causem menor impacto ambiental.

Tabela 16 Exemplos de pessimismo tecnológico envolvendo poluição

(105) As atividades industriais e os veículos de transporte têm liberado nos últimos anos uma quantidade colossal de $\mathrm{CO}_{2}(\mathrm{~g})$ na atmosfera, gerando grande preocupação com um possível aquecimento global (efeito estufa). Verificou-se, porém, que quando a pressão parcial do gás carbônico na atmosfera aumenta, cresce paralelamente a solubilidade do $\mathrm{CO}_{2}(\mathrm{~g})$ nas águas dos oceanos. (C1, L2, p. 257)

(106) Tecnologia do desperdício: se esses gases que estão sendo queimados fossem aproveitados, menos petróleo seria consumido e menos gases do efeito estufa seriam lançados na atmosfera. (C2, L2, p. 303)

(107) Por trás dos aparelhos de alta tecnologia, como celulares, computadores, tablets e máquinas fotográficas, que divertem e facilitam a vida de uma pequena parte da população mundial, há o custo voraz da degradação do meio ambiente, da água, do solo, do ar, além da perda de saúde de uma grande parte da população, justamente aquela que, por ironia, não tem acesso a esses aparelhos. (C1, L2, p.262)

(108) A produção de metais para atender à demanda da sociedade tecnológica exige a extração de grandes quantidades de minérios. Esses processos de extração agridem muito o ambiente e, se não tratados adequadamente, podem causar enormes problemas ambientais. (C2, L3, p. 270)

(109) [...] você já pensou que seu velho televisor pode estar envenenando uma criança na China ou que seu antigo computador esteja contaminando um rio na Nigéria? (C1, L2, p. 264)

(110) O aumento do efeito estufa, no entanto, é um fenômeno relacionado ao aumento de produção de gases estufa na sociedade tecnológica em que vivemos. (C3, L3, p. 50)

(111) Poluição eletromagnética é o excesso de radiações invisíveis às quais estamos submetidos o tempo todo. Grande parte dessas radiações é proveniente da enorme quantidade de aparelhos eletroeletrônicos com os quais convivemos diariamente, como computadores, celulares, televisores, videogames, aparelhos de microondas, máquinas de lavar roupa, liquidificadores e uma infinidade de outros. (C1, L1, p.150)

O livro também discute a questão do lixo eletrônico, proveniente de artefatos tecnológicos e como ele polui o meio ambiente. Podemos perceber também uma reflexão a respeito do modo de vida atual, marcado pelo consumo de produtos tecnológicos, o que gera muito lixo que será depositado no meio ambiente, afetando a vida de muitas pessoas. É possível perceber uma relação entre a questão tecnológica e a questão econômica, onde o livro coloca que a maioria das pessoas de baixa classe social não tem acesso a artefatos 
tecnológicos, enquanto nos países desenvolvidos a quantidade de lixo eletrônico produzido é muito grande.

Na tabela 16 são discutidos exemplos dos malefícios da tecnologia na degradação ambiental. São discutidos vários tipos de poluição como a térmica, eletromagnética, das águas, do ar, etc. Toda essa destruição é associada ao lixo, aos artefatos tecnológicos e aos resíduos liberados por indústrias. Nesses trechos, pode-se constatar que a tecnologia e as indústrias são apresentadas como responsáveis diretas pela degradação ambiental. O livro também discute muito a questão do lixo eletrônico, consequência da utilização de artefatos tecnológicos. A concepção de tecnologia passada aos alunos nesses casos é como sendo algo ruim e que destrói a natureza. A coleção traz várias reflexões sobre a questão ambiental envolvendo o uso de artefatos tecnológicos que pode ser interessante para o aluno refletir sobre a questão da vida atual e fazer melhores escolhas que levem em consideração o meio ambiente.

Outra questão bastante abordada nas coleções é o consumismo, como já foi possível perceber em alguns trechos anteriores. Nos trechos apresentados na tabela 17, a tecnologia é associada ao consumismo, onde as pessoas passam a adquirir cada vez mais artefatos tecnológicos, muitas vezes influenciadas pela propaganda. Assim, cada vez se produz mais lixo o que causa mais impactos ambientais. Além disso, isso causa desigualdade social, pois muitos acabam adquirindo diversos produtos, enquanto outros não possuem o mesmo poder de compra. A desigualdade aparece também nos efeitos nocivos que a poluição acarreta.

Tabela 17 Exemplos relacionados ao consumismo

(112) O desperdício acontece de várias formas. Uma delas é o consumo de quantidades maiores do que as necessárias. O descarte de um bem em boas condições de uso para substituí-lo por um mais novo é outro modo comum de desperdício. Quantas pessoas trocam de celular só para terem um modelo mais "moderno"? $\mathrm{O}$ desperdício pode ser causado pelo uso inadequado de um equipamento ou material. Ligar um aparelho elétrico em uma voltagem maior, não lubrificar engrenagens, fazer uso inadequado para a função desejada são exemplos de atitudes que podem ocasionar danos aos equipamentos. (C2, L2, p.11)

(113) Todos os dias milhares de celulares são descartados. Você já pensou na quantidade de lixo potencialmente tóxico produzido? (C2, L3, p. 262)

(114) Todos os dias, no mundo inteiro, milhares de computadores e seus equipamentos periféricos (teclados, mouses, monitores, impressoras, etc.) vão literalmente para o lixo. Com o avanço da tecnologia na informática, eles se tornam obsoletos cada vez mais depressa. A solução encontrada por muitos usuários e empresas é a troca dos computadores antigos por novos, mais eficientes, rápidos e com maior capacidade de memória. Essa renovação chega a ocorrer a cada dois anos ou menos e, muitas vezes, acontece sem que ocorra a reciclagem dos componentes dos aparelhos antigos. (C4, L3, p. 264)

(115) Lembre-se de que o custo do seu celular ou do seu computador provavelmente é muitíssimo superior ao que pagou por eles, pois custaram vidas, torturas e escravidão. Por isso, tente usá-los durante a sua vida útil não comprando já um novo só porque é moda ou tem funcionalidades extras de que na realidade não precisa. Até porque o lixo eletrônico produzido tem outros custos muito elevados. (C1, L2, p. 295) 
Nos exemplos da tabela 17 os livros discutem a questão do consumo exagerado de produtos tecnológicos, relacionando com a quantidade de lixo gerada e a pobreza. Esse tipo de exemplo pode ser muito importante para ocasionar discussões sobre a relação tecnologia e sociedade.

Em 116 o livro procura associar os artefatos tecnológicos com o sedentarismo, levando a uma reflexão sobre o modo de vida da sociedade atual, que utiliza os artefatos como forma de lazer. Também é abordada a questão da propaganda, muito importante para a questão de mercado dos artefatos tecnológicos. Como o mercado visa a obter lucros, a propaganda é uma forma de se buscar cada vez mais lucros, levando as pessoas ao consumo desenfreado de produtos para abastecer o sistema. Segundo Silva (2003), a propaganda atua como uma forma de alienar a população, pois para vender produtos ressalta seus pontos positivos e esconde os negativos. A propaganda também acaba mostrando a tecnologia como um conhecimento restrito à um grupo de especialistas, como os engenheiros. A imagem expressa pela propaganda é que para o cidadão comum não cabe refletir sobre a tecnologia, apenas usufruir dela e dos seus benefícios. A propaganda funciona como um veículo formador de opinião, portanto devemos questionar as propagandas que nos bombardeam diariamente e refletir sobre elas. Os exemplos 116, 117 e 118 podem servir de ponto de partida para essas discussões em sala de aula. Os exemplos também podem ser importantes para uma reflexão de que a tecnologia nem sempre atende a necessidades reais da sociedade, mas muitas vezes cria as próprias necessidades, por meio da propaganda.

(116) O modelo de vida atual, principalmente nas grandes cidades, leva a criança facilmente ao sedentarismo pois, devido ao intenso movimento nas ruas e à violência, a criança acaba sendo criada "presa" dentro de casa, tendo muitas vezes como única forma de lazer a televisão e o videogame. A propaganda - elaborada com a única intenção de vender produtos, sem nunca julgar se são bons ou ruins cria vontades e necessidades na criança. (C1, L3, p. 208)

Em outros casos, a questão da propaganda para aumentar o consumismo fica ainda mais evidente.

(117) Muitas vezes, porém, em vez de a sociedade determinar quais são os bens de consumo (mercadorias e serviços) de seu interesse, as próprias empresas criam, por meio da mídia, necessidades de consumo de produtos os quais poderiam ser considerados supérfluos e que são consumidos como se fossem essenciais. (C2, L1, p. 17) 
(118) Sem dúvida, a publicidade é um meio eficiente para tornar um bem de consumo conhecido. No entanto, como ela atende a interesses da indústria e do comércio, busca artifícios para atingir pontos vulneráveis do consumidor - vaidade, desejo, gosto e outros. As mulheres das propagandas de cosméticos são muito bonitas, atraentes, magras - parecem ideais. E quando a mídia explora produtos de limpeza, parece que estamos vivendo em uma casa modelo, brilhando e com mobílias novas. Já a imagem do homem é, geralmente, a de pessoa viril, simpática, alinhada, com carro esportivo etc. (C2, L1, p.12)

Também se repete muito nos livros didáticos a questão de relacionar a tecnologia com poder. Quem detém uma tecnologia possui poder sobre os demais, podendo controlá-los. Essa tecnologia pode acabar sendo usada para fins bélicos e para o controle de um grupo de pessoas sobre as outras. Portanto, possuir uma tecnologia ou um artefato está relacionado com poder, e essa disputa de poder pode levar a guerras e conflitos. A obtenção de uma tecnologia está relacionada ao domínio de uma sociedade sobre a outra. Também é abordada a questão da tecnologia usada para fins bélicos e o impacto disso na sociedade. O domínio de uma tecnologia pode levar um país a ter domínio sobre outros, como pode ser observado nos exemplos apresentados na tabela 18

Tabela 18 Exemplos da tecnologia para controle

(119) Nem sempre há equilíbrio entre consumo e produção de petróleo. Essa discrepância fez com que, no século passado, o petróleo se tornasse umas das principais moedas de troca entre as sociedades desenvolvidas tecnologicamente. As disputas pelo domínio e controle do petróleo fizeram surgir guerras, derrubaram governos, levaram à invasão de países, entre outros conflitos. (C2, L2, p. 192)

(120) Após a explosão da bomba atômica, o mundo viveu o período da Guerra Fria, que envolveu o desenvolvimento de um arsenal nuclear muito poderoso, o qual foi desenvolvido sempre com a presença de cientistas. Os países que dominam essa tecnologia e que desenvolveram um enorme parque militar usam de sua influência para impedir que outros países também desenvolvam essa tecnologia. Países emergentes procuram também dispor de tecnologia para enriquecimento de urânio, e isso continua a gerar tensão internacional, apesar do fim da Guerra Fria. (C2, L2, p. 293)

(121) Na Pré-História tribos guerreavam entre si por diferentes motivos. Infelizmente, o sentimento de domínio de um povo sobre o outro permanece até os dias atuais. Com o desenvolvimento da tecnologia, mudaram apenas os métodos. Inicialmente, as batalhas eram corpo a corpo, depois vieram as espadas com o domínio da metalurgia; posteriormente vieram as armas de fogo com a descoberta da pólvora; e assim prosseguiu, até chegarem às bombas atômicas. (C2, L2, p. 309)

(122) Dominar a tecnologia do enriquecimento de urânio e possuir armas nucleares faz um país ser "levado a sério". Em busca desse objetivo ou de outros menos evidentes, países como a Coreia do Norte e o Irã estão seguindo por esse caminho, mesmo sem o aval da Organização das Nações Unidas (ONU), deixando o mundo apreensivo. (C1, L3, p. 317)

Nessa questão de poder, geralmente está envolvido o uso de materiais radioativos, que além de ser usado para fins bélicos, também podem ocorrer acidentes, como mostra o seguinte trecho. 
(123) Em 11 de março de 2011, Fukushima substituiu Chernobyl como sinônimo de acidente nuclear. Chernobyl e Fukushima possuíam reatores com tecnologia completamente diferente, mas passaram por acidentes de mesmo nível de gravidade. (C2, L2, p. 306)

Além da questão de controle, a tecnologia está sendo associada no livro como a responsável pelo desemprego e assim causadora de desigualdades sociais.

(124) Por outro lado, devemos considerar também que a nova revolução industrial gerou seus próprios problemas ao introduzir a robótica nas indústrias e estabelecer mudanças nas relações de trabalho, como a terceirização, caracterizada pela prestação autônoma de serviços. Acompanhando essas alterações, vem crescendo no mundo todo o fenômeno do desemprego, que atualmente tem sido denominado desemprego estrutural. Esse problema surgiu com a reengenharia organizacional das empresas, por sua vez atribuídas às alterações de mercado, como as decorrentes de novos hábitos de consumo; mudanças em normas regulatórias do comércio internacional, de leis ambientais; novas tecnologias etc.. (C2, L3, p. 176)

O livro também atribui uma visão maléfica à tecnologia no seguinte exemplo, onde ela é vista como a responsável pela produção de novas drogas ou como potencializadora de drogas existentes, que afetam a humanidade. Também é relacionada à questão tecnológica com a questão econômica, pois avanços podem aumentar a produção de certos produtos, tornando-os mais baratos.

(125) Entretanto, historicamente, a sociedade não tem avaliado muito bem os riscos do uso de uma nova droga ou uma nova forma de uso de uma velha droga. Por exemplo, a partir do começo do século XX, inovações tecnológicas tornaram a produção de cigarros mais fácil, tornando a absorção da nicotina muito mais eficaz do que ocorria anteriormente. Além disso, o preço do cigarro caiu dramaticamente. (C1, L3, p. 115)

O livro também traz um exemplo em que um processo tecnológico prejudicou a saúde das pessoas envolvidas. Esse exemplo mostra a importância de se estudar sobre os efeitos de uma tecnologia na saúde.

(126) Durante a Primeira Guerra Mundial, uma tinta à base de rádio e fósforo era usada em instrumentos de navegação aérea [...]. Quando a guerra acabou esta tecnologia foi usada em mostradores e ponteiros de relógios. As mulheres empregadas nesta tarefa costumavam passar as pontas dos pincéis na boca para afinar o traço e sem saber acabaram engolindo pequenas parcelas de rádio e comprometendo sua saúde. Depois de dois anos, nove mulheres que eram pintoras de mostrador morreram com uma grave e inexplicável anemia, acompanhada por lesões na boca e mandíbula. Um dentista que tinha tratado uma destas mulheres finalmente fez a conexão entre a inflamação do osso da mandíbula com a tinta dos relógios. [...] (C4, L2, p. 279) 
Em outro exemplo também se discute a importância de se considerar os efeitos de uma tecnologia.

(127) A utilização de um novo material ou de uma nova tecnologia deve considerar não só o instante de utilização, mas também o antes e o depois. Utilizar uma pilha aparentemente é uma ação sem consequências. Entretanto, extrair metais para sua confecção e descartá-la de forma inadequada pode causar sérios danos ambientais. $\mathrm{O}$ conhecimento científico nos aponta caminhos para resolver problemas já colocados por esse avanço tecnológico. (C2, L3, p. 269)

Foram encontrados nas quatro coleções 58 exemplos de situações em que a tecnologia é vista como algo negativo.

\subsection{Otimismo Tecnológico}

Aqui serão apresentados exemplos em que a tecnologia é vista como algo benéfico, que pode auxiliar a vida do ser humano. A tecnologia é vista como promotora de progresso, melhor qualidade de vida, melhor expetativa de vida e bem-estar. A ideia do otimismo tecnológico também pode ser encontrada na literatura com e nome de perspectiva salvacionista da tecnologia, onde acredita-se que tudo que a tecnologia produz é para salvar e melhorar a vida do ser humano.

Muitos acreditam que a tecnologia surgiu com a finalidade de proporcionar melhor qualidade de vida ao ser humano e que não é capaz de causar nenhum mal. Como já exposto anteriormente, Barros Filho et al. (2009) mostram que muitos alunos de ensino médio acreditam que a tecnologia é sempre benéfica ao ser humano e melhora sua qualidade de vida. Kist e Ferraz (2010) também nos mostram que muitos professores possuem a ideia de que a tecnologia é sempre benéfica, essa ideia também é apontada por Auler e Delizoicov (2001).

Nos exemplos da tabela 19 são apresentados os benefícios de tecnologias que podem reverter os próprios malefícios causados pela mesma. É abordada a questão da criação de uma tecnologia para minimizar os efeitos causados pela própria tecnologia, como a questão ambiental. Os exemplos mostram que o ser humano tem buscado alternativas para reduzir os impactos negativos da tecnologia na sociedade. 
Tabela 19 Exemplos da tecnologia para reverter estragos da tecnologia

(128) Tecnologia minimiza riscos ambientais da exploração do xisto: Já os especialistas afirmam que o sucesso dos americanos nessa tecnologia vai acabar modificando o cenário mundial, como explica Adriano Pires, diretor do Centro Brasileiro de Infraestrutura. Os riscos ambientais ligados à extração do gás e do petróleo de xisto existem, mas são idênticos aos de outros tipos de combustíveis fósseis, segundo estudiosos. Os principais riscos são a contaminação dos lençóis freáticos, o desperdício de água e o vazamento de metano. Esses fatores fazem com que a reprovação popular seja um freio importante para o aumento da exploração do xisto, de acordo com Edmar de Almeida, membro do Grupo de Economia de Energia da UFRJ e consultor em energia. (C1, L3, p. 57)

(129) Novas tecnologias já estão disponíveis para possibilitar o uso simultâneo de diferentes resíduos plásticos, sem que haja incompatibilidade entre elas e a consequente perda de resistência e qualidade. A chamada "madeira plástica", feita com a mistura de vários plásticos reciclados, é um exemplo. (C1, L3, p. 215) e (C1, L1, p. 68)

(130) O que fazer com os resíduos sólidos que não podem ser reaproveitados nem reciclados? Diversas tecnologias foram desenvolvidas para dar o tratamento adequado a esse material. No entanto, o problema maior reside no fato de que junto a esses resíduos está uma quantidade enorme de materiais que não deveria ter sido descartada, pois poderia ter sido reaproveitada ou reciclada. (C2, L1, p. 68)

(131) Entre os grandes desafios da indústria para a preservação do ambiente, está o desenvolvimento de tecnologias que possibilitem transformar produtos poluentes em materiais úteis. Nessa usina, o bagaço da cana-de-açúcar é utilizado como combustível a ser queimado para gerar energia. (C2, L3, p. 177)

Ainda considerando os efeitos do desenvolvimento tecnológico na sociedade, as coleções abordam que uma alternativa para minimizar os efeitos da poluição seria a reciclagem. As coleções consideram a questão da reciclagem como uma tecnologia (tabela 20).

Tabela 20 Processo de reciclagem como uma tecnologia

(132) O ideal é a adoção de um sistema circular, em que o lixo seja reaproveitado e seus materiais façam parte do ciclo novamente. Nesse sentido, a tecnologia de reciclagem é peça fundamental na economia de recursos naturais, pois visa aprimorar a taxa de reciclagem de materiais, a qualidade dos materiais reciclados e a viabilidade econômica e ambiental dos processos industriais envolvidos. (C3, L1, p. 93)

(133) Cerca de $90 \%$ dos materiais empregados na fabricação de aparelhos de informática podem ser reciclados - o que implica separar até o ouro, utilizado para fabricar uma das partes mais importantes dos computadores: o processador, responsável pelo gerenciamento de todas as funções. (C4, L3, p. 264)

A tecnologia também pode ser usada para fazer coisas que o ser humano seria incapaz de fazer, como nos exemplos apresentados na tabela 21 , que buscam tornar a tecnologia mais acessível ao ser humano. 
Tabela 21 Tecnologia como capaz de fazer coisas que o ser humano seria incapaz de fazer

(134) Imagine alguém usar a mesma cueca várias semanas sem problemas de higiene. Isso é possível graças à tecnologia dos materiais, favorecida pela nanotecnologia. Cientistas japoneses desenvolveram um tipo de tecido autolimpante que repele líquidos e pode até matar bactérias que causam o mau cheiro. Nos EUA, os militares em combate usam esse tipo de roupa para evitar trocas e lavagens. (C2, L3, p. 310)

(135) (Fotografia da Terra produzida em 1972 pelos tripulantes da missão Apollo 17) A obtenção de imagens como esta resulta da aplicação do conhecimento científico e tecnológico acumulado pelo ser humano durante muitos anos e em diferentes áreas das ciências, entre elas a Química. (C4, L1, p. 11)

(136) Laser, nanotecnologia e bactérias. Não, esses não são elementos de uma história de ficção científica são ferramentas em estudo na Petrobras para facilitar a extração de petróleo nas reservas do pré-sal, que ficam a $300 \mathrm{~km}$ da costa e a mais de $4 \mathrm{~km}$ de profundidade, incluindo $2 \mathrm{~km}$ da coluna de água e mais $2 \mathrm{~km}$ da camada de sal. [...] (C1, L3, p. 12)

As coleções também apresentam diversos exemplos em que a tecnologia foi utilizada para a melhoria de lavouras, garantindo assim mais alimento para atender o aumento da população mundial. Esses exemplos são mostrados na tabela 22.

Tabela 22 Tecnologia na melhoria de lavouras

(137) Por essa razão, é fundamental conhecer a função e a disponibilidade desses elementos químicos em relação aos vegetais a fim de ter condições de interferir de maneira positiva no desenvolvimento de novas tecnologias que venham aumentar a produtividade e melhorar a qualidade da lavoura. (C2, L1, p. 185)

(138) No século XX, o crescimento populacional foi explosivo, proporcional aos avanços tecnológicos que permitiram a irrigação, a mecanização da agricultura, a utilização de fertilizantes e pesticidas químicos. A demanda pelo aumento da produtividade agrícola implicou o desenvolvimento de novas tecnologias. A nova ordem se fez e os sistemas de produção foram modificados. As lavouras foram mecanizadas e os insumos agrícolas, usados com mais frequência. Esse desenvolvimento, que colocou mais comida na mesa das pessoas, teve contribuição significativa da Química. (C2, L1, p. 185)

(139) O desenvolvimento tecnológico contribui de forma significativa para o aumento da produtividade agrícola, elevando a quantidade de alimentos produzida por área cultivada. Esse aumento de produtividade possibilitou uma maior disponibilidade de alimentos para a população. (C2, L1, p. 218)

A tecnologia também é vista como benéfica devido às suas aplicações na medicina, que podem salvar vidas e aumentar a longevidade do ser humano (Tabela 23).

Tabela 23 Tecnologia na medicina

(140) Também não se pode dizer que todo produto artificial causa prejuízos à saúde. Populações humanas existem hoje graças à interferência maciça do ser humano na natureza. Essa interferência se dá, por exemplo, por meio do desenvolvimento de técnicas agrícolas, as quais garantem a produção de alimentos, e de tecnologias médicas e farmacêuticas relacionadas à produção de medicamentos capazes de controlar inúmeras doenças. (C4, L1, p. 20)

(141) O uso benéfico da radioatividade na sociedade é variado, e o uso de tal tecnologia, em alguns casos, é vital. Além da geração de eletricidade, já citada, outros usos já estão inseridos fortemente em nosso cotidiano, entre eles podemos citar: a conservação dos alimentos; a produção de medicamentos (os radiofármacos) e os aparelhos para exames de diagnóstico; o uso das técnicas para aumentar a produtividade agrícola; a fabricação de peças industriais que exigem precisão e qualidade etc.. (C2, L2, p. 293)

(142) Uma forma segura de determinar a extensão de uma fratura, por exemplo, é o uso de equipamentos de raios X. Para que avanços tecnológicos como esse pudessem estar presentes, não só na medicina, mas também, por exemplo, na produção industrial, um grande passo teve de ser dado pelos cientistas: a concepção científica do modelo atômico. (C4, L1, p. 84) 
Também são expostos os benefícios da tecnologia na indústria de beleza, para a produção de cosméticos.

(143) A indústria química fornece um arsenal completo de produtos a favor da beleza, entre os quais: fármacos, maquiagens, cremes - antirrugas, contra celulites, rejuvenescedores -, drogas para emagrecer ou ganhar músculos, xampus, tinturas, alisadores para o cabelo e outros. Uma infinidade de produtos químicos que favorecem a beleza das pessoas são produzidos com a mais alta tecnologia e são consagrados entre os profissionais que trabalham com a estética. (C2, L3, p. 17)

A tecnologia também auxiliou no desenvolvimento do tratamento de água (tabela 24), possibilitando água potável para um número maior de pessoas e facilitando o seu tratamento e posteriormente o seu reuso.

Tabela 24 Tecnologia no tratamento de água

(144) Por isso é tão importante o reuso da água que possibilita diminuir a quantidade de esgoto e, assim, diminuir o impacto da ação humana no ambiente e na sua biodiversidade. Nesse sentido, novas tecnologias têm surgido com o objetivo de diminuir o consumo de água potável e, ao mesmo tempo, facilitar seu reuso. (C2, L2, p. 102)

(145) Há vários milênios, japoneses e chineses já utilizavam processos de filtração em porcelanas para tratar as águas de consumo. Por conta do surgimento das cidades, houve um avanço nas tecnologias para o tratamento da água, desenvolvidas com base no reconhecimento das infecções causadas por água contaminada, principalmente por resíduos humanos, em reservatórios para abastecimento público. (C2, L2, p. 163)

Os livros também abordam a questão da utilização da tecnologia para a produção de energia (tabela 25).

Tabela 25 Tecnologia para a produção de energia

(146) As pilhas de níquel-metal-hidreto (Ni-MH) são as mais usadas atualmente, dado seu valor e modelos disponíveis no mercado. Elas contam com as vantagens de não provocar o "efeito memória", de oferecer maior tempo de vida, maior capacidade e suportar mais recargas. Mesmo assim, existem pilhas tecnologicamente mais avançadas. (C2, L3, p.262)

(147) Atualmente os modernos aparelhos eletroeletrônicos usam baterias do tipo íons de lítio, conhecidas como Lítio Íon. Com maior tecnologia envolvida na produção, esse tipo de baterias é o mais vantajoso do mercado, o que tem vida útil e capacidade de carga maior, ou seja, dura mais, compensando seu preço mais alto. Além disso, essas baterias podem ser projetadas para ter tamanhos e massa reduzidos, já que empregam na sua fabricação materiais de baixa densidade. (C2, L3, p.262)

A tecnologia também tem sido utilizada nas indústrias de alimentos para modificar produtos, tornando-os melhores ou mais atrativos para o consumo, conforme trechos apresentados na tabela 26 . 
Tabela 26 Tecnologia na melhoria de produtos

(148) Com o desenvolvimento da indústria alimentícia, surgiu a necessidade de novas tecnologias que possibilitassem aumentar o estoque, a conservação, a variedade e a facilidade de preparo dos alimentos. Isso estimulou a busca de novos conhecimentos e novidades tecnológicas que mantivessem ou aumentassem o valor mercadológico dos alimentos. (C2, L3, p. 59)

(149) Na busca por novas moléculas aromáticas, pesquisadores viajam o mundo tentando descobrir que cheiro têm as coisas e o que pode ser aproveitado. [...] realiza expedições anuais por vários países, coletando todo tipo de material que possa ter cheiro - seja numa avenida movimentada de um centro urbano ou numa floresta tropical. Hoje há mais de 6000 moléculas aromáticas conhecidas. O diferencial de cada empresa está na tecnologia utilizada nos processos e naquelas poucas moléculas que a concorrência desconhece. (C4, L3, p. 100)

Outros exemplos abordam a importância da tecnologia para a globalização, facilitando a comunicação entre pessoas de lugares distantes. Também se mostra que a tecnologia modificou a forma de viver e de se comunicar das pessoas (tabela 27).

Tabela 27 Tecnologia na comunicação

(150) A nossa sociedade atual é profundamente diferente das comunidades agrárias que a originaram. A principal marca dessa diferença está no elevado grau de desenvolvimento tecnológico. Ele reduziu drasticamente a distância relativa entre os países e rompeu barreiras de comunicação, em um processo de globalização no qual o planeta tem sido considerado uma grande aldeia, em que todos podem se comunicar quase que instantaneamente. (C2, L3, p. 172)

(151) As radiações estão presentes no dia a dia de todos. Vão desde a claridade e o calor vindos do Sol, até a melodia do despertador musical. Vários aparelhos fazem uso das radiações e, em razão disso, têm propiciado facilidades e melhorias no cotidiano das pessoas. Um exemplo é a telefonia celular: no Brasil, em junho de 2012, chegou-se à média de 130,44 aparelhos para cada 100 habitantes, ou seja, havia mais de um celular para cada brasileiro (dados fornecidos pela Anatel - Agência Nacional de Telecomunicações). Outro exemplo é o uso da Internet, uma rede mundial que encurtou a distância e o tempo da transmissão de informações. (C4, L2, p. 278)

A tecnologia também foi utilizada para a melhoria de artefatos da própria tecnologia, como a melhoria de carros e máquinas fotográficas (tabela 28).

Tabela 28 Tecnologia na melhoria de artefatos (152) As câmeras que funcionam com filmes fotográficos - muito usadas por mais de cem anos - estão sendo cada vez mais substituídas pelas câmeras digitais. A máquina da fotografia abaixo remonta ao final do século XIX, quando o equipamento era destinado basicamente a fotógrafos profissionais. No século XX e início do século XXI, elas passaram por inúmeras modificações, como redução de tamanho e massa, facilidade de manuseio e melhor definição das imagens. Essas mudanças e a redução de preços popularizaram as câmeras, presentes hoje em celulares e outros aparelhos eletrônicos. (C4, L2, p 201)

(153) Os primeiros veículos elétricos surgiram no século XIX. Antes, porém, que algumas barreiras enfrentadas pelas indústrias de automóveis elétricos fossem superadas, como as limitações de tempo de recarga e autonomia, o lançamento e o sucesso de vendas de veículos movidos a combustíveis fósseis mudaram a tendência da época. A partir de então, esses veículos passaram a dominar o mercado. Atualmente, a indústria de veículos elétricos voltou a ser impulsionada por questões ambientais e pela perspectiva de escassez das reservas de combustíveis fósseis. (C4, L2, p. 245) 
Em outros dois trechos aparecem de forma explícita que a tecnologia pode melhorar a qualidade de vida do ser humano (tabela 29).

Tabela 29 Tecnologia na melhoria da qualidade de vida

(154) A ideia dominante do ponto de vista econômico é a de que o crescimento está alicerçado no aumento contínuo da produção e do consumo de bens e serviços, reconhecidos como meios de promover a prosperidade e a qualidade de vida para o maior número possível de pessoas. Isso se fundamenta no modelo de desenvolvimento contínuo da ciência e tecnologia, que para muitos implica desenvolvimento social. (C2, L1, p. 10)

(155) As conquistas tecnológicas obtidas pela sociedade trouxeram riqueza e melhor qualidade de vida, embora esses benefícios não estejam disponíveis a todos. (C2, L1, p. 75)

Outros exemplos (tabela 30) também discutem a importância da energia para nossa atual sociedade, que só é possível através de tecnologias.

Tabela 30 Tecnologia na questão de energia

(156) Percebe-se, assim, que no contexto geral o Brasil tem se destacado quanto à busca de uma matriz energética baseada em fontes renováveis. Em 2007, cerca de 46\% da energia consumida eram originários de fontes renováveis, enquanto a média mundial era apenas de 12\% (vide tabela abaixo). Essa distribuição foi favorecida graças a variados fatores que, ao longo do tempo, se acertaram, como por exemplo o uso do álcool como combustível. Na tentativa de aliviar tensões do setor produtor de açúcar e contornar a crise do petróleo, o governo incentivou o programa Proálcool, que de lá para cá, entre erros e acertos, tem hoje papel de destaque na economia do país, dado o desenvolvimento tecnológico ocorrido ao longo do tempo. (C2, L2, p. 304)

(157) O uso de pilhas e baterias é intenso em nossa sociedade. Muitas vezes, nem nos damos conta de como essa tecnologia está presente em nosso cotidiano. Nos dias atuais, dificilmente um jovem ou adulto passa o dia sem ter uma pilha ou bateria consigo. Elas estão presentes em tantos equipamentos que nem nos damos conta. Poucos relógios modernos não utilizam baterias. Qualquer celular funciona à base de bateria. $(\mathrm{C} 2, \mathrm{~L} 3$, p. 240)

Foram encontrados ao todo nas coleções analisadas 67 exemplos em que a tecnologia é vista como algo positivo. Aqui apresentou-se apenas alguns desses exemplos. A quantidade de exemplos em que a tecnologia é vista como algo positivo é superior aos exemplos em que ela é vista como negativa.

\subsection{Acessibilidade da tecnologia}

As coleções 1, 2 e 4 abordam a respeito da acessibilidade da tecnologia, mostrando em alguns trechos que a consideram acessível a todos ou acessível apenas a uma pequena parcela da população. 
Alguns trechos das coleções fazem uma crítica em relação à tecnologia, dizendo que ela é acessível apenas a uma pequena parte da população (tabela 31). A crítica dos livros é em relação às desigualdades sociais, onde nem toda a população consegue ter acesso aos artefatos tecnológicos, devido às condições financeiras.

Tabela 31 Acessível a poucos

(158) Por trás dos aparelhos de alta tecnologia, como celulares, computadores, tablets e máquinas fotográficas, que divertem e facilitam a vida de uma pequena parte da população mundial, há o custo voraz da degradação do meio ambiente, da água, do solo, do ar, além da perda de saúde de uma grande parte da população, justamente aquela que, por ironia, não tem acesso a esses aparelhos. (C1, L2, p.262)

(159) As conquistas tecnológicas obtidas pela sociedade trouxeram riqueza e melhor qualidade de vida, embora esses benefícios não estejam disponíveis a todos. (C2, L1, p.75)

(160) Entretanto, como temos discutido neste livro, apesar de todo desenvolvimento, apenas uma pequena parcela da população tem usufruído mais diretamente os benefícios gerados pelo avanço tecnológico, enquanto a maioria continua excluída, sem acesso a eles. (C2, L3, p. 172)

(161) No país ainda é grande o número de pessoas que não dispõem de recursos financeiros para comprar um computador, fato que contribui para aumentar o índice de excluídos do acesso aos recursos da informática. Quais práticas consideradas comuns atualmente esses indivíduos deixam de realizar por não terem acesso a um microcomputador? (C4, L3, p. 264)

Em outras ocasiões, é expresso que a tecnologia está atingindo um número cada vez maior de pessoas, tornando-se acessível à maior parte da população (tabela 32).

Tabela 32 Acessível a muitos

(162) Hoje, todos dependem do computador. O trânsito das grandes cidades, os caixas de supermercados, a contagem de votos em uma eleição, as transmissões de TV e até mesmo o fornecimento de água e luz são exemplos de atividades controladas por computadores. (C2, L1, p.17)

(163) As radiações estão presentes no dia a dia de todos. Vão desde a claridade e o calor vindos do Sol, até a melodia do despertador musical. Vários aparelhos fazem uso das radiações e, em razão disso, têm propiciado facilidades e melhorias no cotidiano das pessoas. Um exemplo é a telefonia celular: no Brasil, em junho de 2012, chegou-se à média de 130,44 aparelhos para cada 100 habitantes, ou seja, havia mais de um celular para cada brasileiro (dados fornecidos pela Anatel - Agência Nacional de Telecomunicações). Outro exemplo é o uso da Internet, uma rede mundial que encurtou a distância e o tempo da transmissão de informações. (C4, L2, p. 278)

Em outros trechos, não se fala a respeito da acessibilidade da tecnologia em si, mas de que a tecnologia aumentou a produção de alguns produtos, tornando esses produtos mais acessíveis à população em geral (tabela 33). 
Tabela 33 Produtos mais acessíveis

(164) As câmeras que funcionam com filmes fotográficos - muito usadas por mais de cem anos - estão sendo cada vez mais substituídas pelas câmeras digitais. A máquina da fotografia abaixo remonta ao final do século $\mathrm{XIX}$, quando o equipamento era destinado basicamente a fotógrafos profissionais. No século XX e início do século XXI, elas passaram por inúmeras modificações, como redução de tamanho e massa, facilidade de manuseio e melhor definição das imagens. Essas mudanças e a redução de preços popularizaram as câmeras, presentes hoje em celulares e outros aparelhos eletrônicos. (C4, L2, p 201)

(165) A ideia dominante do ponto de vista econômico é a de que o crescimento está alicerçado no aumento contínuo da produção e do consumo de bens e serviços, reconhecidos como meios de promover a prosperidade e a qualidade de vida para o maior número possível de pessoas. Isso se fundamenta no modelo de desenvolvimento contínuo da ciência e tecnologia, que para muitos implica desenvolvimento social. (C2, L1, p.11)

Além dos trechos em que é dito explicitamente que a tecnologia é acessível apenas a uma pequena parte da população, a coleção apresenta trechos em que se questiona se a tecnologia é acessível ou não (tabela 34). O objetivo desses trechos é que o aluno reflita se a tecnologia é ou não é acessível a todos.

Tabela 34 Reflexão sobre acessibilidade da tecnologia

(166) Ocorre, porém, que por trás de todo esse desenvolvimento temos questões éticas a serem discutidas. Dentre outras questões, podemos citar: Quem tem se beneficiado dessas tecnologias? Como são distribuídos esses benefícios? Quais são as implicações ambientais? Essa tecnologia permanecerá nas mãos de poucos grupos ou será disponibilizada aos interessados? (C2, L3, p. 11)

(167) Há muito tempo, muitas sociedades vêm procurando banir a prática da exploração econômica de seres humanos. Políticas de combate a essa prática vêm sendo desenvolvidas em nosso país contra a escravidão de trabalhadores rurais, a exploração sexual de crianças e adolescentes e o tráfico internacional de mulheres para exploração sexual. Ocorre que, como fruto da tecnologia da Engenharia Genética, abriu-se um novo e poderoso mercado de comercialização da vida, por meio do mercado negro de tráfico de órgãos, de tráfico de embriões, de tráfico de animais, e outros. Daí surge outra questão ética por trás da mercantilização: a quem se deve destinar os benefícios dessa tecnologia. Todas as novas tecnologias precisam ser testadas. E quem serão as cobaias? Os animais, que não têm como opinar? Como garantir um padrão de confiabilidade? (C2, L3, p.12)

Em geral, podemos perceber que a tecnologia é vista pelas coleções como acessível a poucos. Assim, as coleções aproveitam o momento para inserir discussões a respeito de aspectos sociais da tecnologia, relacionando com uma abordagem CTS. Em $59 \%$ dos exemplos, a tecnologia é vista como acessível apenas a uma pequena parcela e se discute a questão da pobreza e desigualdades sociais. Em $12 \%$ dos exemplos é feita uma discussão sobre a acessibilidade da tecnologia, discutindo se a tecnologia é acessível ou não, mas levando o aluno a pensar que ela não atinge toda a população. Em 29 \% dos exemplos, a tecnologia é vista como sendo acessível à maior parte da população. Apenas a coleção 3 não discute sobre a acessibilidade da tecnologia, não realiza essa discussão sobre as desigualdades sociais, onde nem todos podem ter acesso aos artefatos produzidos. 


\subsection{Neutralidade da Tecnologia}

Nesta categoria se enquadram os trechos em que a tecnologia não é vista como maléfica e nem benéfica, mas depende do seu uso (tabela 35). A tecnologia por si só é vista como neutra e seus produtos podem ser usadas por fins que beneficiam a humanidade ou fins que são maléficos à humanidade.

Tabela 35 Neutralidade da tecnologia

(168) Fala-se muito na possibilidade de um ataque terrorista nuclear, caso algum grupo radical tenha acesso a material radioativo retirado de aparelhos destinados a aplicações pacíficas. E enquanto países fortemente armados estudam diminuir seu arsenal atômico, outros, que não possuem armas nucleares, estão investindo no enriquecimento de urânio, a matéria-prima necessária para fabricá-las. Insensatez. Por outro lado, não podemos desprezar os inúmeros benefícios que essa tecnologia pode trazer, quando usada com responsabilidade e fiscalização constante. Ter uma noção mais clara de todos os riscos e possibilidades da atividade nuclear é fundamental para o desenvolvimento da cidadania. (C1, L3, p. 289)

(169) De fato o modelo tecnológico atual tem uma contradição: ao mesmo tempo que contribui para a melhoria da qualidade de vida também traz diversos problemas para a sociedade. (C2, L1, p. 16)

(170) O desenvolvimento da agroindústria associado ao uso de maquinários especiais aumentou a produtividade agrícola, mas trouxe também sérios problemas ambientais. (C2, L1, p. 18)

(171) São incontestáveis suas contribuições para a preservação da vida, mesmo quando é usada para fins militares. Afinal, são inúmeras as tecnologias amplamente usadas que trazem aumento de qualidade de vida e que foram desenvolvidas para fins de guerra. Vários gases tóxicos, inseticidas e herbicidas também foram testados em guerras e posteriormente passaram a ter aplicações no controle da proliferação de pragas, reduzindo a mortalidade e aumentando a produção mundial de alimentos, com redução do seu preço e aumento de sua disponibilidade. (C2, L2 p. 291)

(172) Exemplos não faltam de casos de tecnologias que produziram resultados positivos para a vida da população, mas que provocaram milhares de mortes posteriormente. Já discutimos nesta coleção diversos exemplos dessa dualidade da química, como os benefícios do DDT e os impactos ambientais por ele provocados; o ganho tecnológico do uso do CFC e o seu efeito na destruição da camada de ozônio; e o aumento da produtividade que tem sustentado a população global com uso de adubos sintéticos e agrotóxicos e problemas ambientais. Muitos outros podem ser relacionados, como os benefícios do tratamento de câncer com a radioterapia e os problemas com acidentes com materiais radioativos, como o ocorrido em Goiânia e que será discutido na última unidade deste livro. (C2, L3, p. 11)

(173) No entanto, o avanço científico e tecnológico não tem só vantagens. Ao mesmo tempo que a tecnologia aproxima pessoas conectadas com o mundo distante, ela também afasta outras que estão ao seu redor. Conquistamos cada vez mais o espaço, mas não vencemos a distância que nos separa da miséria na qual vive a maior parte da população. Aumentamos a expectativa de vida, mas deixamos que nossos jovens morram pelo uso de droga ou aliciamento do crime. Criamos remédios que curam doenças antes letais, mas também criamos armas tecnológicas que podem matar milhares com um simples apertar de botão”. (C2, L3, p. 289)

Segundo Veraszto et al. (2008) essa ideia afirma que a tecnologia não é boa nem má, seu uso é que pode ser inadequado. Isso retira da tecnologia e de seus fabricantes qualquer tipo de responsabilidade na sua concepção, deixando a responsabilidade apenas a quem faz uso desse tipo de tecnologia. Essa visão pode ignorar os interesses sociais, econômicos e 
políticos dos que idealizam e controlam uma tecnologia. A produção de um artefato pode carregar diversos interesses políticos e que precisam ser considerados ao discutir sobre tecnologia. A produção de um artefato costuma envolver interesses, como pode ser constatado nos exemplos de cultura tecnológica intrínseca. $\mathrm{O}$ artefato em si pode ser considerado neutro, entretanto é necessário considerar os interesses por trás da sua utilização.

Por outro lado, essa visão pode auxiliar os alunos a não ter medo da tecnologia e compreender que os interesses da tecnologia estão ligados à sociedade. A maior parte dos exemplos dessa categoria, presentes nas coleções abordam a questão da radioatividade e energia nuclear. Esse tipo de assunto costuma assustar os alunos que podem considerar a radioatividade sempre maléfica, mas também podem levar às reflexões que os façam considerar os benefícios da sua utilização. Apesar dos benefícios, é importante que o aluno seja consciente dos malefícios que ela pode causar, opinando sobre o assunto e pressionando os governos, especialistas em tecnologias, organizações e empresas para mais cuidados com relação a materiais desse tipo, buscando evitar acidentes nucleares e a utilização para fins bélicos. Esse tipo de exemplo também pode levar os alunos a refletirem sobre questões políticas e de poder envolvidas nesses processos. Os exemplos não estão mostrando a tecnologia como neutra e sim que ela depende de fatores sociais e políticos e para isso a participação da sociedade nas questões é de grande importância. Os cidadãos não podem assistir alheios a todas essas questões, mas devem opinar e pressionar para que sua participação seja efetiva.

Em exemplos como o 170, as coleções abordam a questão do aumento da produção de alimentos e produtos utilizados para isso, que apesar de produzir alimentos para uma quantidade maior de pessoas provocou impactos ambientais. É importante considerar os custos e benefícios de cada tecnologia e procurar tecnologias menos agressivas ao ambiente. Por outro lado, é importante inserir discussões que a questão da fome não é somente devido a quantidade de alimentos produzida, mas envolve questões como desigualdade social e desperdício.

Em outros exemplos como 169 e 172 a tecnologia é abordada de forma mais geral, considerando que toda tecnologia pode trazer benefícios e malefícios à sociedade. Em 171 são citados vários exemplos de tecnologias que foram produzidas com finalidades bélicas, mas 
posteriormente foram utilizadas de forma positiva. Entretanto, a produção da tecnologia não foi neutra, seu uso posterior é que teve outra finalidade.

Em outro exemplo, mostra a questão de uma tecnologia criada para beneficiar o ser humano, mas que pode ter pontos negativos. Em nome dos lucros, alguns pontos negativos podem não ser levados em consideração para que a tecnologia seja amplamente aceita.

(174) Os sistemas de ventilação foram se tornando cada vez mais sofisticados. O emprego de computadores, usados para variar as quantidades de ar que entram no edifício, fez com que os gastos de energia reduzissem. A temperatura e a umidade são os únicos critérios usados para medir a qualidade do ar interior nesses sistemas, sendo que outros parâmetros indicadores de qualidade foram ignorados. $(\mathrm{C} 1, \mathrm{~L} 1, \mathrm{p}$. 254)

A imagem que o livro didático mais divulga é da tecnologia como sendo algo positivo e os exemplos de pessimismo tecnológico e neutralidade tecnológica estão em menor número, como podemos ver no gráfico 4 . Ao total, foram encontrados 148 exemplos em que se discute se a tecnologia ou determinado artefato é positivo, negativo ou neutro. Desses exemplos, $45 \%$ mostram a tecnologia como sendo algo positivo, capaz de melhorar a vida do ser humano; $39 \%$ dos exemplos mostra a tecnologia de forma pessimista, como responsável por desastres ambientais e desigualdade social; $15 \%$ apresenta a tecnologia como neutra, seu uso é que pode ser bom ou mau.

Os dados mostram que os livros apesar de mostrarem a tecnologia como algo benéfico trazem alguns exemplos para que os alunos reflitam sobre possíveis impactos negativos da tecnologia. Dessa forma, a tecnologia não é vista como a salvação da humanidade, mas também não é vista como a única responsável por todos os problemas sociais. 
Gráfico 2: Tecnologia é boa ou má?

\section{Tecnologia é boa ou má?}

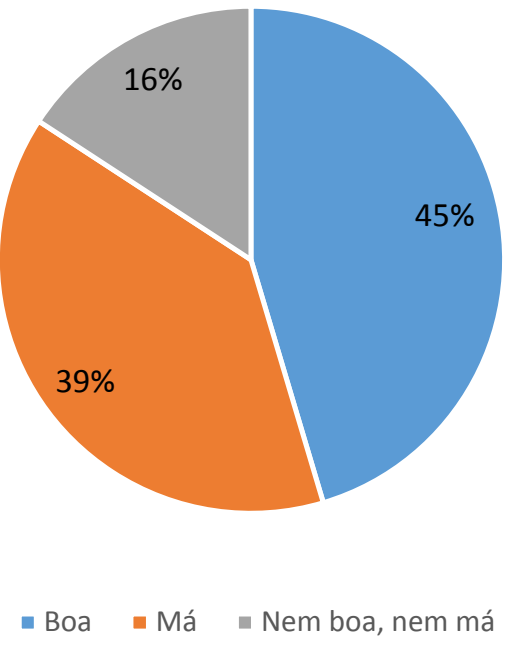

\subsection{Tecnologia muda a forma de ver o mundo}

Nessa subcategoria serão apresentados alguns exemplos em que se diz que a tecnologia é capaz de mudar a forma de ver o mundo, modificando o estilo de vida das pessoas (tabela 36).

Tabela 36 Tecnologia muda a forma de ver o mundo

(175) Tudo isso gerou uma estrondosa revolução, que está marcando uma nova era para a humanidade: graças à mudança no modo de ver o mundo e de interpretar o seu comportamento. A sociedade tecnológica do novo milênio tem outra visão de mundo. $\mathrm{O}$ mundo globalizado possibilita a aproximação de pessoas distantes, que acompanham instantaneamente fatos ocorridos do outro lado do planeta. (C2, L3, p. 289)

(176) No final do século XIX, os conhecimentos da Física clássica estavam bem estabelecidos. Avanços significativos em várias áreas - mecânica, termodinâmica, eletricidade e eletromagnetismo - tinham possibilitado a compreensão de diversos fenômenos e o desenvolvimento de novas tecnologias. A invenção da máquina a vapor, a utilização da eletricidade nas indústrias e residências, a invenção de motores, o telégrafo, tudo isso estava contribuindo para mudar o modo de vida das pessoas. (C3, L1, p. 173)

Feenberg (2010) destaca que a tecnologia é uma das principais fontes de poder na sociedade moderna, portanto é comum que ela dite grandes modificações na estrutura da sociedade e molde o estilo de vida das pessoas. Segundo Medeiros e Ventura (2007), a tecnologia tem causado muitas mudanças em nossas crenças, costumes e comportamentos, modificando nossa cultura. As mudanças tecnológicas ocorrem em uma grande velocidade e 
hoje temos uma nova forma de viver em sociedade. Para atuar em nossa nova sociedade, é necessária uma nova forma de comportamento, chamada pelos autores de cultura tecnológica.

É importante que o aluno tenha a visão de que a tecnologia modifica a sociedade, estabelecendo relações entre a ciência, tecnologia e sociedade. Essas relações estão estabelecidas nos documentos oficiais como um ponto importante que os livros devem debater, seria imprescindível que os livros didáticos apontassem ainda mais exemplos desse tipo.

\subsubsection{Discussão geral da tecnologia em cada uma das coleções de livros didáticos}

Foram encontrados ao todo 368 exemplos de tecnologia ou relacionados à tecnologia nos livros didáticos pesquisados. Desses exemplos, $51 \%$ são da coleção 2, $23 \%$ são da coleção 4, $17 \%$ são da coleção 1 e apenas $7 \%$ são da coleção 3. A coleção 2 é a que mais aborda a questão tecnológica e a coleção 3 a que menos aborda. $\mathrm{O}$ gráfico 3 mostra essa relação:

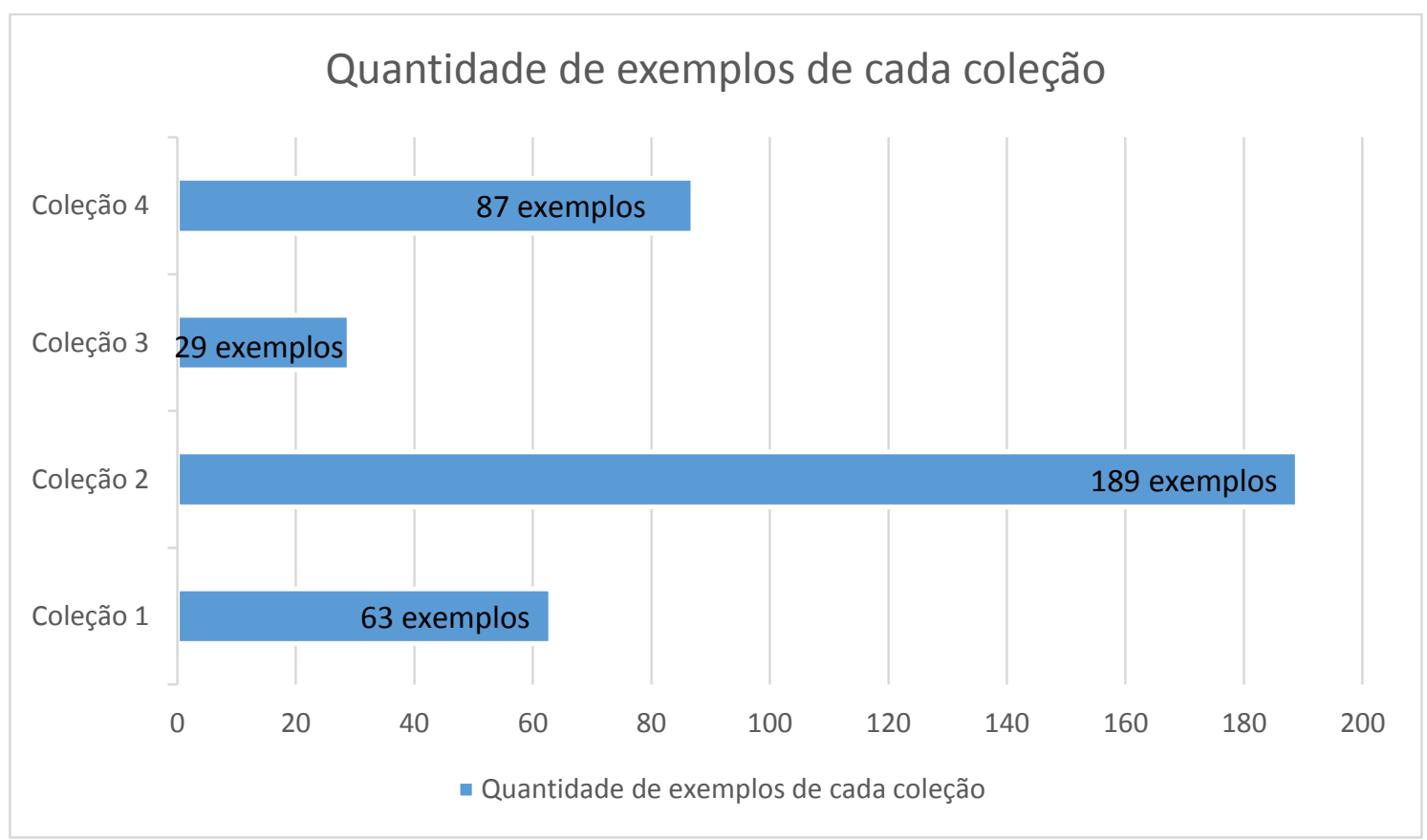

Gráfico 3: Comparação entre a quantidade de exemplos que discutem sobre tecnologia de cada coleção

Resultados e Discussões 
Como pode ser observado no gráfico 3 , a coleção de livros didáticos número 2 foi a que mais abordou a questão tecnológica em seus livros didáticos, apresentando 189 exemplos de trechos que discutiam a questão tecnológica. Essa coleção foi a que mais prometeu em sua apresentação no início dos livros que iria abordar a questão tecnológica e, portanto, considerando a quantidade de exemplos expostos, a coleção cumpriu o objetivo a que se propôs. Isso pode estar relacionado à questão de os autores estarem relacionados com a pesquisa em ensino de ciências, principalmente na questão CTS. Entretanto, mesmo essa coleção tendo apresentado uma quantidade grande de exemplos, a colação apresentou diversos exemplos da tecnologia como ciência aplicada e como técnica.

A coleção 3 foi a que apresentou a menor quantidade de exemplos, apenas 29 exemplos relacionados à tecnologia. $\mathrm{Na}$ apresentação dos livros da coleção 3 , os autores também não fazem nenhuma referência a abordagem da tecnologia.

A tabela 37 apresenta a quantidade de exemplos de cada coleção em relação ao significado da tecnologia, para cada uma das categorias propostas.

Tabela 37 Quantidade de exemplos de cada coleção em relação ao significado da tecnologia

\begin{tabular}{l|l|l|l|l}
\cline { 2 - 5 } & Coleção 1 & Coleção 2 & Coleção 3 & Coleção 4 \\
\hline $\begin{array}{l}\text { Tecnologia como } \\
\text { Ciência Aplicada }\end{array}$ & 19 & 47 & 14 & 32 \\
\hline $\begin{array}{l}\text { Ciência deriva da } \\
\text { tecnologia }\end{array}$ & 2 & 12 & 2 & 3 \\
\hline $\begin{array}{l}\text { Tecnologia ou } \\
\text { Técnica }\end{array}$ & 0 & 9 & 0 & 3 \\
\hline $\begin{array}{l}\text { Discussão do } \\
\text { significado da } \\
\text { tecnologia }\end{array}$ & 0 & 2 & 0 & 0 \\
\hline
\end{tabular}

Com os dados da tabela 37 podemos visualizar como o significado da tecnologia é visto em cada uma das coleções separadamente. A coleção 2, como esperado por ser a coleção com mais exemplos, é a que traz mais exemplos da tecnologia como ciência aplicada, sendo 47 exemplos. Entretanto, ela também traz 12 exemplos que ilustram o contrário, onde a ciência é vista como derivada da tecnologia. A coleção 4 também apresenta uma grande quantidade de exemplos da tecnologia como ciência aplicada. Um ponto interessante a ser analisado é que as coleções 1 e 3 não trouxeram nenhum exemplo da tecnologia como sinônimo de técnica. Um fator preocupante é que apenas a coleção 2 discutiu explicitamente sobre o significado da tecnologia. Isso mostra que, apesar da promessa das coleções em 
discutir sobre tecnologia, discussões sobre o seu significado não são realizadas explicitamente e a tecnologia é apresentada apenas de forma implícita, na maioria das vezes como ciência aplicada.

Em relação à segunda família de categorias, a cultura tecnológica, os dados podem ser visualizados na tabela 38 .

Tabela 38 Quantidade de exemplos de cada coleção em relação à cultura tecnológica

\begin{tabular}{l|l|l|l|l}
\cline { 2 - 5 } & Coleção 1 & Coleção 2 & Coleção 3 & Coleção 4 \\
\hline $\begin{array}{l}\text { Cultura tecnológica } \\
\text { intrínseca }\end{array}$ & 9 & 25 & 3 & 1 \\
\hline $\begin{array}{l}\text { Cultura tecnológica } \\
\text { extrínseca }\end{array}$ & 29 & 89 & 9 & 40 \\
\hline $\begin{array}{l}\text { Pessimismo } \\
\text { tecnológico }\end{array}$ & 17 & 25 & 4 & 13 \\
\hline $\begin{array}{l}\text { Otimismo } \\
\text { tecnológico }\end{array}$ & 7 & 39 & 2 & 20 \\
\hline $\begin{array}{l}\text { Acessibilidade da } \\
\text { tecnologia }\end{array}$ & 2 & 12 & 0 & 3 \\
\hline $\begin{array}{l}\text { Neutralidade da } \\
\text { tecnologia }\end{array}$ & 2 & 12 & 1 & 3 \\
\hline $\begin{array}{l}\text { Muda a forma de } \\
\text { ver o mundo }\end{array}$ & 1 & 1 & 2 & 1 \\
\hline
\end{tabular}

Com base na tabela 38, é possível verificar que novamente a coleção 2 é a que mais apresenta exemplos de cultura tecnológica intrínseca e extrínseca. No caso da cultura tecnológica intrínseca apontamos para a pequena quantidade de exemplos em todas as coleções, principalmente na coleção 4 .

Em relação à cultura tecnológica extrínseca, temos exemplos nas quatro coleções de pessimismo tecnológico e otimismo tecnológico, o que pode ser apontado como um ponto positivo nas coleções pois a tecnologia não tem sido vista como salvacionista da humanidade e nem como a culpada por todos os problemas. Esses exemplos são importantes para apresentarem duas visões da tecnologia, como maléfica e benéfica e não mostrar apenas uma visão equivocada da tecnologia como nociva ou salvadora. Essas duas visões podem gerar um debate em sala de aula, discutindo pontos positivos e negativos da tecnologia que auxiliem em uma visão crítica do aluno.

Nas coleções 1 e 3 podem ser observados mais exemplos de pessimismo tecnológico, sendo nesses livros a tecnologia vista como algo mais negativo que positivo. Essa visão é mais acentuada na coleção número 1 em que se destaca uma forte discussão sobre aspectos 
ambientais, onde a questão tecnológica foi normalmente associada com impactos ambientais. Na coleção 1 a tecnologia é enfatizada como causadora de diversos impactos ambientais e é apresentada uma densa discussão a respeito do lixo tecnológico e o consumismo desenfreado de produtos tecnológicos.

Nas coleções 2 e 4 percebe-se um maior número de exemplos de otimismo tecnológico, sendo a tecnologia encarada mais de forma positiva. Neste ponto destaca-se a coleção 1, onde são apresentados diversos pontos positivos da tecnologia, principalmente ligados à medicina e ao aumento da produção de alimentos.

Em relação à discussão sobre acessibilidade da tecnologia, a coleção 3 não trouxe nenhuma discussão desse tipo e destaca-se a quantidade de exemplos da coleção 2. A neutralidade da tecnologia pode ser vista em todas as coleções de livros didáticos, com mais exemplos na coleção 2 também. A visão de que a tecnologia é capaz de mudar a forma de ver o mundo foi vista de forma bem discreta em todas as coleções. Sugere-se que essa categoria deveria ser mais bem explorada em livros didáticos futuros.

Com uma visão geral sobre as quatro coleções, aponta-se para a potencialidade da coleção 2, com a maior quantidade de exemplos em que a tecnologia é discutida. Em todas as categorias a coleção 2 se destaca em suas discussões, sendo um livro com um denso conteúdo sobre tecnologia. Entretanto a coleção 2 também apresenta algumas visões bem equivocadas e problemáticas da tecnologia. A coleção 1 destaca-se pelas discussões em que se relaciona a questão ambiental e a tecnologia, conforme proposto nos documentos oficiais e nos editais de avaliação do PNLD. A coleção 4 pode ser notada pela grande quantidade de exemplos em que é explicado o funcionamento tecnológico de artefatos. A coleção 3 foi a com discussões mais escassas sobre o tema. Todas as coleções apresentam a visão equivocada da tecnologia como ciência aplicada. 


\section{CONCLUSÕES}

O ensino de tecnologia é recomendado por vários autores da área e também está sugerido nos documentos oficiais da área de ensino de ciências analisados e editais de avaliação do PNLD. Hoje é muito importante e um grande desafio promover um ensino de tecnologia em sala de aula. O movimento CTS sugere que relações entre ciência, tecnologia e sociedade devem ser inseridas em sala de aula, visando à formação de cidadãos mais críticos.

Revisou-se as principais concepções de tecnologia e educação tecnológica presentes na literatura. Por meio desse levantamento bibliográfico realizado fica claro uma grande dificuldade em compreender a tecnologia. Quando se fala em tecnologia, geralmente acreditase que ela é uma aplicação da ciência, salvacionista e neutra, como mostram diversos artigos analisados neste trabalho.

Ao analisar as compreensões sobre tecnologia de alguns autores, chegou-se à conclusão que os próprios filósofos não possuem um consenso no conceito de tecnologia. Para o propósito deste trabalho, utilizou-se a definição de Bunge (1985) que entende a tecnologia como "o estudo científico do artificial". Para o autor, a tecnologia se utiliza de elementos científicos, mas não pode ser considerada apenas como ciência aplicada e deve ser vista como um modo de conhecimento com suas próprias regras e teorias. Apesar dessa indefinição no significado da tecnologia por parte dos filósofos, com a discussão teórica realizada anteriormente, é possível perceber que é um consenso a questão de a tecnologia não ser apenas a aplicação de conhecimentos científicos. Neste trabalho, defende-se este ponto, que a tecnologia não é mera ciência aplicada.

Ao discutir como é abordada a tecnologia, nos documentos oficiais da área de ensino de Ciências, chegou-se à conclusão de que a tecnologia é bastante valorizada, sendo citada em todos os textos e, por diversas vezes, é citada também a importância de uma educação tecnológica. A tecnologia é vista como uma das dimensões que o ensino deve estar baseado, sendo as demais: trabalho, ciência e cultura. Os documentos oficiais sugerem que a tecnologia seja abordada de forma a possibilitar ao aluno conhecer os produtos da tecnologia. Também é direcionado que o aluno deve compreender o funcionamento dos artefatos tecnológicos, o processo histórico da tecnologia e entender os impactos sociais da tecnologia. Um ensino CTS também tem sido sugerido nos documentos oficiais. 
Percebe-se que os documentos oficiais utilizam um discurso sedutor, enaltecendo a importância da tecnologia e da educação tecnológica, mas sem um maior direcionamento. Nota-se que na prática esse discurso está distante do que pode ser visto nos livros didáticos e que outras pesquisas mostram em relação à formação de professores.

No processo de avaliação dos livros didáticos, a tecnologia também aparece como um fator a ser avaliado. No edital do PNLD que direciona as editoras com os critérios para a escolha dos livros, a tecnologia aparece como um fator importante. $\mathrm{O}$ edital sugere que as coleções devem abordar a tecnologia, relacionando-a com as questões ambientais. Uma educação em uma perspectiva CTS também é direcionada no edital. Outro ponto importante, é que os livros devem abordar o funcionamento dos artefatos tecnológicos, pois esse seria um conhecimento bastante importante para o aluno.

No Guia do Livro Didático também ocorre uma menção à tecnologia. O Guia apresenta a disciplina química como muito importante, pelo fato das pessoas estarem inseridas numa sociedade tecnológica. Percebe-se que no Guia a tecnologia é usada como uma justificativa para a aprendizagem da ciência. O Guia também aponta para a importância de um ensino CTS. O GLD e o edital do PNLD utilizam um discurso bastante semelhante aos documentos oficiais, enaltecendo a tecnologia e educação tecnológica. Entretanto, na prática esse discurso torna-se difícil de ser consolidado.

$\mathrm{Na}$ análise dos livros didáticos pode-se perceber que a tecnologia como um conteúdo não aparece em nenhum momento. Ela sempre é colocada como uma exemplificação para discutir um conteúdo químico. Nenhum dos livros didáticos dedicou um espaço maior para abordar exclusivamente a tecnologia como um conteúdo central, ela foi inserida nos capítulos que abordam conhecimentos químicos. Dessa forma, os livros didáticos não trazem um ensino de tecnologia e sim um ensino de química, utilizando exemplos da tecnologia para ilustrar. Também percebemos que a tecnologia aparece mais como uma forma de exemplificação e de justificativa da aprendizagem da ciência. Acredita-se que não seria necessário discutir a tecnologia em um capítulo separado do texto, entretanto seria interessante que ela tivesse mais destaque nas discussões e não aparecesse apenas camuflada em conteúdos científicos.

Neste trabalho, analisou-se as principais abordagens de tecnologia presentes nos livros didáticos de Química. Para caracterizar essas principais abordagens de tecnologia, criou-se algumas categorias de análise, divididas em dois blocos de análise: significado da tecnologia e 
cultura tecnológica. Discutiu-se cada uma das abordagens presentes nos livros e comparou-se as coleções entre si.

Em relação ao significado da tecnologia, foram encontrados 156 exemplos nas quatro coleções de livros didáticos investigadas. Desse total de exemplos, $79 \%$ mostra a tecnologia como ciência aplicada. Pode-se perceber que a concepção dos livros, de forma geral, é da tecnologia como sendo ciência aplicada. Esse resultado concorda com a literatura, pois o levantamento bibliográfico realizado nos periódicos brasileiros mostrou que em nove trabalhos que abordam concepções de tecnologia, a tecnologia como ciência aplicada é a concepção que mais se destaca. Outros autores como Acevedo (2003) Silva (2003), Fourez (2003) e Ricardo (2015) também apontam para essa concepção, que é a mais comum apontada pela literatura. A ideia defendida neste trabalho é que a tecnologia não pode ser vista apenas como a aplicação de conhecimentos científicos, mas é importante que os alunos compreendam que a tecnologia também cria conhecimentos próprios, possui suas próprias regras, normas e teorias. A ideia da tecnologia como ciência aplicada resulta em um modelo linear de desenvolvimento científico e tecnológico, onde primeiro surge a ciência e depois a tecnologia seria a aplicação dela. Vários episódios da história, como a máquina a vapor e a luneta de Galileu desmentem esse modelo.

Dos exemplos retirados dos livros didáticos somente $12 \%$ possuem uma visão contrária à ideia exposta acima. Esses exemplos mostram casos em que a tecnologia foi vista como anterior à ciência ou que ambas foram vistas como interdependentes. Esses casos podem ser importantes, pois podem desmitificar a ideia de tecnologia como ciência aplicada, mostrando que assim como a tecnologia utiliza conhecimentos científicos para se desenvolver, a ciência utiliza conhecimentos da tecnologia ou a própria tecnologia para se aperfeiçoar, mostrando que uma não é a aplicação imediata da outra, mas são campos distintos que se relacionam. Apesar de esses casos serem importantes, a quantidade de exemplos classificados nessa categoria foi relativamente baixa.

Em 7\% dos casos a tecnologia foi considerada como sinônimo de atividades técnicas, como cozer alimentos e a utilização de ferramentas. Percebe-se, então, uma confusão entre o conceito de tecnologia e técnica. Atividades técnicas estão sendo consideradas pelos livros didáticos como tecnologias, ocorrendo uma confusão entre os dois conceitos. Essa indefinição das duas atividades causa uma discordância na coleção número 2 , pois a mesma coleção em 
um momento aborda que a tecnologia é uma atividade recente da humanidade, que surgiu com a revolução industrial e em outro momento aborda que a tecnologia surgiu com a utilização do fogo. E, em outros, foram mostrados casos em que o desenvolvimento científico recebeu uma ajuda da tecnologia. Assim, seria necessário que os livros didáticos assumissem um posicionamento sobre o que estão considerando uma tecnologia ou uma atividade técnica.

A discussão do significado da tecnologia aparece apenas em dois exemplos da coleção número 2 de livros didáticos. As demais coleções não discutem mais abertamente o que entendem por tecnologia ou o seu surgimento. A única coleção que faz essa associação é a número 2. Um dos pontos apontados nos PCNEM é que sejam trabalhados na escola aspectos históricos do desenvolvimento da ciência e da tecnologia. Entretanto, em relação à tecnologia, não se viu isso acontecer. Apenas em um exemplo da coleção 2 foi vista essa associação.

Os livros também apresentam alguns exemplos em que é vista a cultura tecnológica intrínseca, discutindo a questão de patentes, regras dos sistemas tecnológicos e aspectos econômicos que interferem no processo tecnológico. Esses exemplos, embora poucos, se bem explorados, podem ser importantes para que os alunos percebam que a tecnologia possui suas próprias características e não pode ser reduzida à aplicação do conhecimento científico.

A cultura tecnológica extrínseca também aparece nos livros didáticos. Para essa análise foram criadas subcategorias. Em relação ao pessimismo tecnológico foram encontrados 59 exemplos, $39 \%$ dos exemplos. O objetivo das citações é mostrar que a tecnologia possui implicações negativas na sociedade, como a devastação ambiental, problemas de saúde na população, consumismo desenfreado de artefatos que acaba gerando uma grande quantidade de lixo e poluindo o meio ambiente e desemprego por redução do número de trabalhadores em indústrias visto o aumento da quantidade de máquinas. Esses exemplos podem ser importantes para que os alunos compreendam as implicações sociais da tecnologia na sociedade. Em relação aos impactos ambientais, esses exemplos estão seguindo a orientação dos PCNEM, que abordam a importância de trabalhar a relação entre a tecnologia e os aspectos ambientais.

Exemplos em que a tecnologia ocasionou coisas positivas na sociedade também são vistos na subcategoria de otimismo tecnológico, que aparece em 45,2\% dos exemplos. Nessas citações, a tecnologia é vista como a responsável pelo aumento da produção de alimentos, aumento da expectativa de vida do ser humano, melhorias na medicina e aproximação das 
pessoas a partir dos meios de comunicação. Em 17 exemplos, a tecnologia também é vista capaz de reverter os malefícios causados por ela mesma. A quantidade de casos em que a tecnologia é vista como um benefício é superior à quantidade de casos em que a tecnologia é vista como algo ruim, $45 \%$ e $39 \%$ dos exemplos, respectivamente. Em 15\% dos casos, a tecnologia é vista como neutra, onde ela não seria boa nem ruim, mas seu uso pode levar para os dois caminhos.

Pode-se perceber que na maioria dos casos a tecnologia é vista de forma otimista, embora a quantidade de casos em que ela é vista de forma pessimista não seja tão baixa. É importante que o aluno não tenha a visão de que a tecnologia só traga coisas boas, mas também não é necessário que ele acredite que a tecnologia seja a única responsável por todos os problemas da humanidade. O aluno deve compreender que a tecnologia possui suas implicações na sociedade, tanto positivas quanto negativas.

Os livros também trazem a discussão de como a tecnologia modificou a forma de ver o mundo das pessoas e a nossa maneira de viver. Essa ideia difundida pelos livros é importante para que os alunos sejam conscientes dos impactos da tecnologia na sociedade e em sua vida pessoal. Os alunos podem ser conscientizados sobre como é importante, não apenas utilizar a tecnologia, mas estudar, opinar e discutir sobre ela. A imagem que os livros didáticos passam é da tecnologia como não acessível a todos, podendo levar os alunos a refletir sobre as desigualdades sociais.

Assim, os livros trazem alguns exemplos em que as implicações da tecnologia na sociedade foram discutidas. Acredita-se que esses exemplos nos livros podem gerar ótimas discussões na sala de aula. Porém, a tecnologia como um conteúdo não aparece em nenhum momento. Também são escassas as discussões a respeito da origem, história e significado da tecnologia. Os livros didáticos poderiam inserir algumas discussões desse tipo, apresentando alguns tópicos sobre história e filosofia da tecnologia, de forma acessível ao aluno. Essa discussão pode vir até mesmo a derrubar a ideia habitualmente aceita da tecnologia como mera ciência aplicada.

Apesar dos livros apresentarem algumas discussões interessantes, a imagem passada na maioria dos exemplos pelos livros didáticos ainda é da tecnologia como ciência aplicada. Não se pode afirmar que os professores irão transmitir essa ideia aos seus alunos, entretanto, considerando que é uma concepção apontada em vários trabalhos presentes na literatura e que 
é a ideia transmitida pelos livros didáticos, acredita-se que essa ideia pode vir a ser incorporada pelos alunos. Também pode-se inferir que os livros didáticos podem estar contribuindo para que os professores mantenham uma visão distorcida sobre a tecnologia.

A tecnologia foi apresentada nos livros mais como fonte de exemplificação do que como fonte de conteúdo e também foi utilizada no livro como uma forma de justificar a aprendizagem da ciência. Assim, aparecem contradições entre as concepções de tecnologia veiculadas nos livros e as estabelecidas nos documentos oficiais e editais de avaliação. Tais contradições dificultam o trabalho dos professores em sala de aula e podem estar na raiz das visões equivocadas encontradas do termo. Dessa forma, trabalhar efetivamente a tecnologia em sala de aula requer uma mudança na postura tradicional, que tende a reduzir a tecnologia à mera ciência aplicada. Tal mudança passa necessariamente pela atualização de algumas ideias veiculadas pelos livros didáticos.

Dada a importância de se abordar a tecnologia na educação básica, apresentada aqui tanto pela literatura quanto pelos documentos oficiais, ainda são necessárias algumas mudanças para se trabalhar a tecnologia efetivamente em sala de aula.

Aponta-se como possíveis dificuldades para trabalhar a questão tecnológica em sala de aula: a falta de consenso na literatura no que se refere à tecnologia, como foi explicitado na revisão bibliográfica sobre o tema; visões distorcidas dos professores e falta de uma maior discussão na formação de professores como foi explicitado no levantamento bibliográfico; falta de direcionamento nos documentos oficiais que utilizam um discurso sedutor sobre tecnologia mas não apresentam um direcionamento mais claro; visões distorcidas e insuficientes presentes nos livros didáticos que, em alguns casos, trazem imagens erradas ou insuficientes sobre tecnologia ou suprimem algumas discussões importantes. 


\section{REFERÊNCIAS}

ABREU, R. G. Tecnologia e Ensino de ciências: Recontextualização no "novo Ensino médio". Rio de Janeiro: Universidade Federal do Rio de Janeiro, 2008.

ABREU, T. B; FERNANDES, J. P; MARTINS, I. Levantamento sobre a produção CTS no Brasil no período de 1980-2008 no campo de Ensino de ciências. Alexandria Revista de Educação em Ciência e Tecnologia, v.6, n.2, p. 3-32, 2013.

ACEVEDO, J. A. La tecnología en las relaciones CTS: una aproximación al tema. Enseñanza de las Ciencias, v.14, n.1, p.35-44, 1996.

ACEVEDO, J. A.; VASQUEZ, A.; MANASSERO, M. Evaluación de actitudes y creencias CTS: diferencias entre alumnos y profesores. Revista de Educación, 328, p. 355-382, 2002 .

ACEVEDO, J. A.; VASQUEZ, A.; MANASSERO, M.; ACEVEDO, P. R. Creencias sobre la tecnología y sus relaciones con la ciência. Revista Electrónica de Enseñanza de las Ciencias, v. 2, n. 3, p. 353-376, 2003.

AIKENHEAD, G. Educación Ciencia-Tecnología-Sociedad (CTS): una buena idea como quiera que se le llame. Educación Química, v. 16, n.2, p. 114-124, 2005.

AMARAL, C. L. C.; XAVIER, E. S.; MACIEL, M. L. Abordagem das relações ciência/tecnologia/sociedade nos conteúdos de funções orgânicas em livros didáticos de química do Ensino médio. Investigações em Ensino de Ciências, v.14, n.1, p.101-114, 2009.

AMORIM, A. C. R. Biologia, tecnologia e inovação no currículo do Ensino Médio. Investigações em Ensino de Ciências, v3, n.1, p. 61-80, 1998.

ANGOTTI, J. A. P.; AUTH, M. A. Ciência e tecnologia; implicações sociais e o papel da educação. Ciência \& Educação, v. 7, n. 1, p. 15-27, 2001.

ANGOTTI, J. A. P.; BASTOS, F. P.; MION, R. A. Educação em física: discutindo ciência, tecnologia e sociedade. Ciência \& Educação, v. 7, n. 2, p. 183-197, 2001.

ARAÚJO, M. C. P.; GEHLEN, S. T.; MEZALIRA, S. M.; SCHEID, N. M. J. Enfoque CTS na pesquisa em Educação em Ciências: extensão e disseminação. Revista Brasileira de Pesquisa em Educação em Ciências, v. 9, n. 3, 2009.

AULER, D.; BAZZO, W. A. Reflexões para a Implementação do Movimento CTS no Contexto Educacional Brasileiro. Revista Ciência e Educação, v.7, n.1, p.1-13, 2001.

AULER, D.; DELIZOICOV, D. Alfabetização científico-tecnológica para quê? Ensaio Pesquisa em Educação em Ciências, v.3, n.1, 2001. 
BARDIN, L. Análise de Conteúdo. Lisboa, Portugal; Edições 70, LDA, 2009.

BAZZO, W. A. . Introdução aos Estudos CTS (Ciência, Tecnologia e Sociedade). Cadernos de Ibero-América- OEI. Madri, 2003.

BISPO, F.; MACIEL, M. D.; SEPINI, R. P.; ALONSO, A. V. Alfabetização Científica sob o enfoque da ciência, tecnologia e sociedade: implicações para a formação inicial e continuada de professores. Revista Electrónica de Enseñanza de las Ciências, vol. 12, n.2, p.313-333, 2013.

BORGMANN, A. Technology and the character of contemporary life: a philosophical inquiry. Chicago: The University of Chicago Press, 1984.

BRASIL. Constituição da República Federativa do Brasil. Brasília: Senado Federal; Centro Gráfico, 1988.

Lei de Diretrizes e Bases da Educação Nacional - LDB. Lei nº 9394/96.

PCN+ Ensino Médio: Orientações Educacionais complementares aos Parâmetros Curriculares Nacionais. Brasília: Ministério da Educação, 2002

BRASIL, Secretaria da Educação Média e Tecnológica. Parâmetros Curriculares Nacionais para o Ensino Médio. Brasília: Ministério da Educação, 1999.

BRASIL, Secretaria da Educação Básica. Base Nacional Comum Curricular, 2a edição preliminar. Brasília: Ministério da Educação, 2016.

Diretrizes Curriculares Nacionais da Educação Básica. Brasília: Ministério da Educação, 2013.

Orientações Curriculares para o Ensino médio: Ciências da natureza, matemática e suas tecnologias. Brasília: Ministério da Educação, 2006.

Guia de livros didáticos PNLD 2015 - Ensino Médio. Brasília: Ministério da Educação, 2014.

BUNGE, M. Dicionário de Filosofia. São Paulo: Perspectiva, 2006.

Philosophy of science and technology: formal and physical sciences, Treatise on basic philosophy, Dordrecht: Reidel, 1985.

CACHAPUZ, A.; GIL-PÉREZ, D.; PESSOA, A. M.; PRAIA, J.; VILCHES, A. A necessária renovação do ensino das Ciências. São Paulo: Cortez, 2005.

CACHAPUZ, A.; PAIXÃO, F.; LOPES, J. B.; GUERRA, C. Do estado da arte da pesquisa em educação em ciências: linhas de pesquisa e o caso "ciência-tecnologia-sociedade". Alexandria - Revista de Educação em Ciência e Tecnologia, v. 1, n. 1, p. 27-49, 2008. 
CAETANO, S. S.; LINSINGEN, I. V. Concepções Sobre o Conhecimento Tecnológico e a Estrutura Curricular dos Cursos Técnicos. Revista Brasileira de Ensino de Ciência e Tecnologia, v. 4, n. 3, 2011.

CASSAB, M. A Democracia como balizadora do Ensino das Ciências na Escola: Como discutir este desafio? Revista Brasileira de Pesquisa em Educação em Ciências, v. 8, n. $2,2008$.

CHASSOT, A. Alfabetização científica: questões e desafios para a educação. Ijuí: Editora Unijuí, 2000.

Educação conSciência. Santa Cruz do Sul: EDUNISC, 2003.

. Para que(m) é útil o Ensino? Alternativas para um Ensino (de Química) mais crítico. Canoas: Ed. Da Ulbra, 1995.

CHRISPINO, A.; LIMA, L. S.; ALBUQUERQUE, M. B.; FREIRAS, A. C. C.; SILVA, M. A. F. A área CTS no Brasil vista como rede social: onde aprendemos? Ciência \& Educação, v. 19, n. 2, p. 455-479, 2013.

CHOPPIN, A. História dos livros e das edições didáticas sobre o estado da arte. Educação e Pesquisa, v. 30, n. 3, p. 549- 566, 2004.

COSTA, L. G.; COSTA, A. P. O Ensino de Física das Radiações na Formação de Auxiliares de Enfermagem e Atendentes de Consultórios Odontológicos: Sondagem de Concepções sobre os Raios-X com Enfoque na Prevenção e Tecnologia. Ciência \& Educação, v. 8, n. 2, p.161-165, 2002.

CUNHA, M. B.; GIORDAN, M. As Percepções na Teoria Sociocultural de Vigotski: uma análise na escola. Alexandria, v.5, n.1, p.113-125, 2012.

CUPANI, A. A tecnologia como problema filosófico: três enfoques, Scientiae Studia, vol.2, n. 4, p.493-518, 2004.

Filosofia da tecnologia: um convite. Florianópolis: Ed. da UFSC, 2013. 2006.

La peculiaridad del conocimiento tecnológico, Scientiae Studia, v.4, n.3, p.353-371,

FABRI, F.; SILVEIRA, R. M. C. F. Alfabetização científica e tecnológica nos anos iniciais a partir do tema lixo tecnológico. Revista Brasileira de Ensino de Ciência e Tecnologia, v. 5, n. 2, 2012.

. O Ensino de ciências nos anos iniciais do Ensino fundamental sob a ótica CTS: uma proposta de trabalho diante dos artefatos tecnológicos que norteiam o cotidiano dos alunos. Revista Investigações em Ensino de Ciências, v.18, n.1, p.77-105, 2013. 
FEENBERG, A. Transforming technology a critical theory revisited, New York: Oxford University Press, 2010.

FERREIRA, C.; GIL-PÉREZ, D.; VILCHES, A. Imagen de la tecnología transmitida por los textos de educación tecnológica. Didáctica de las Ciencias Experimentales y Sociales, v. 20, p. 23-46, 2006.

FIRME, R. N.; AMARAL, E. M. R. Concepções de professores de química sobre ciência, tecnologia, sociedade e suas inter-relações: um estudo preliminar para o desenvolvimento de abordagens CTS em sala de aula. Ciência \& Educação, v. 14, n. 2, p. 251-269, 2008.

FOUREZ, G. A constituição das ciências: Introdução à filosofia e à ética das ciências. São Paulo: Editora da UNESP, 1995.

Alfabetización científica y tecnológica: Acerca de las finalidades de la enseñanza de las ciencias. Argentina: Ediciones Colihue, 1997.

Crise no Ensino de ciências?, Revista Investigações em Ensino de Ciências, v.8, n.2, p.109-123, 2003.

FRANCO, M. L. O livro didático e o Estado. ANDE, ano I, n. 5, p. 19-24, 1992.

FREITAS, L. M.; GHEDIN, E. Pesquisas sobre estado da arte em CTS: análise comparativa com a produção em periódicos nacionais. Alexandria Revista de Educação em Ciência e Tecnologia, v.8, n.3, p. 3-25, 2015.

GATTI JUNIOR, D. Dos antigos manuais escolares aos modernos livros didáticos de história no Brasil: dos anos sessenta aos dias atuais. Icône, v.1, n.1, p. 97-116, 2000.

GAYÁN, E.; GARCÍA, P. E como escoger un libro de texto? Desarrollo de un instrumento para evaluar los libros de texto de ciencias experimentales. Enseñanza de las Ciências. Número Extra, V Congresso, p. 249- 250; 1997.

GILBERT, J. Educación Tecnológica: uma nueva asignatura em todo el mundo. Enseñanza de las Ciencias, v. 13, n.1, p.15-24, 1995.

GORDILLO, M.; GALBARTE, J. C. G. Reflexiones sobre la educación tecnológica desde el enfoque CTS. Revista Iberoamericana de Educación, n.28, p. 1-28, 2002.

GOUVÊA, G.; LEAL, M. C. Uma Visão Comparada do Ensino em Ciência, Tecnologia e Sociedade na Escola e em um Museu de Ciência. Ciência \& Educação, v.7, n.1, p.67-84, 2001.

JESUS, C. S.; BÖCK, B. S.; CHRISPINO, A. A Ciência Reguladora e Precaucionária na Análise dos Riscos Tecnológicos. Alexandria, v.7, n.2, p.73-101, 2014. 
KIST, C. P.; FERRAZ, D. F. Compreensão de professores de biologia sobre as interações entre ciência, tecnologia e sociedade. Revista Brasileira de Pesquisa em Educação em Ciências, v.10, n. 1, p. 1-15, 2010.

LINSINGEN, I. V. Perspectiva educacional CTS: aspectos de um campo em consolidação na América Latina. Ciência \& Ensino, Campinas, v. 1, p. 1-16, 2007.

LOPES, N. C. ANDRADE, J. A. N.; QUEIRÓS, W. P. NARDI, R. SOUZA, R. R. CARVALHO, W. L. P. Tendências do movimento CTS em dois eventos nacionais da área de Ensino de ciências. In: XVIII Simpósio Nacional de Ensino de Física, Vitória-Espírito Santo, p.1-10, 2009.

LÜDKE, M., ANDRÉ, M. E. D. A. Pesquisa em Educação: abordagens qualitativas. São Paulo: E.P.U., 1986.

MACEDO, C. C.; SILVA, L. F. Contextualização e Visões de Ciência e Tecnologia nos Livros Didáticos de Física Aprovados pelo PNLEM. Alexandria, v.3, n.3, p.1-23, 2010.

MAIZTEGUI, A.; ACEVEDO, J. A.; CAAMAÑO, A.; CACHAPUZ, A. Papel de la tecnología en la educación científica: una dimensión olvidada. Revista Iberoamericana de Educación, n.28, p.1-19, 2002.

MARTORANO, S. A. A.; MARCONDES, M. E. R. As concepções de ciência dos livros didáticos de química, dirigidos ao Ensino médio, no tratamento da cinética química no período de 1929 a 2004. Investigações em Ensino de Ciências, v. 14, n.3, p. 341-355, 2009.

MARULANDA, C. A. O. La Formación de Ingenieros Para la Participación Pública en Ciencia y Tecnologia. Alexandria, v.1, n.1, p. 91-108, 2008.

MEDEIROS, Z.; VENTURA, P. C. S. O conceito Cultura Tecnológica e um estudo no meio educacional. Ensaio Pesquisa em Educação em Ciências, v. 9, n. 2, 2007.

MIQUELIN, A. F.; SAAVEDRA FILHO, N. C.; CONCEIÇÃO, S. A. H. Mediação da trilogia "Fundação" como possível parâmetro para análises do determinismo tecnológico no Ensino de Ciências. Revista Brasileira de Ensino de Ciência e Tecnologia, v. 7, n. 1, 2014.

NASCIMENTO, S. S.; SANTOS, R.; NIGRI, E. Alfabetização Científica e Tecnológica e a interação com os objetos técnicos. Caderno Brasileiro de Ensino de Física, v. 23, n. 1, p. 53-67, 2006.

NIEZWIDA, N. R. A. A tecnologia como objeto de estudo: tendências de educação tecnológica. In: VII Encontro Nacional de Pesquisa em Educação em Ciência, Florianópolis-Santa Catarina, p.1-12, 2009. 
NIINILUOTO, I. Ciencia frente a Tecnología: ¿Diferencia o identidad? Arbor, v.157, n.620, p. 285-299, 1997.

OLIVEIRA, R. S.; GOMES, E. S.; AFONSO, J. C. O Lixo Eletroeletrônico: Uma Abordagem para o Ensino Fundamental e Médio. Química Nova na Escola, v.32, n.4, 2010.

OLIVEIRA, S.; GUIMARÃES, O. M.; LORENZETTI, L. Uma proposta didática com abordagem CTS para o estudo dos gases e a cinética química utilizando a temática da qualidade do ar interior. Revista Brasileira de Ensino de Ciência e Tecnologia, v.8, n.4, 2015 .

PACEY, A. The culture of technology. Cambridge: MIT Press, 1983.

PIASSI, L. P. Robôs e androides: a abordagem de questões sociopolíticas de ciência e tecnologia em sala de aula. Revista Brasileira de Pesquisa em Educação em Ciências, v. 11, n.3, 2011.

PIASSI, L. P.; PIETROCOLA, M. De Olho no Futuro: Ficção Científica para Debater Questões Sociopolíticas de Ciência e Tecnologia em Sala de Aula. Ciência \& Ensino, v. 1, número especial, 2007.

PINHEIRO, N. A. M.; SILVEIRA, R. M. C. F; BAZZO, W. A. Ciência, tecnologia e sociedade: a relevância do enfoque CTS para o contexto do Ensino médio. Ciência \& Educação. v. 13, n. 1, p. 71-84, 2007.

QUINTANILLA, M. A. Técnica y cultura, Teorema - Revista Internacional de Filosofía OEI, vol. XVII, n.3, p.1-12, 1998.

QUINTANILLA, M.; MERCADO, M. E. GROVES, T.; BECERRA, J. A. M.; SÁNCHEZ, R. P.; PERALES, O. M; MCBRIDE, A. O. Scientific and Technological Culture in ESO Textbooks, Instituto de Estudios de la Ciencia y la Tecnología. Salamanca, 2011.

RICARDO, E. C. La Comunicación Social de la Tecnología Presente en los Libros de Texto de Física en Brasil. Dissertação (Máster Universitário en Cultura Científica y de la Innovación). Universidade de Oviedo - Espanha, 2015.

RICARDO, E. C; CUSTÓDIO, J. F.; REZENDE, M. F. A tecnologia como referência dos saberes escolares: perspectivas teóricas e concepções dos professores. Revista Brasileira de Ensino de Física, v.29, n.1, p.135-147, 2007.

RICARDO, E. C.; FREIRE, J. C. A. A concepção dos alunos sobre a física do Ensino médio: um estudo exploratório. Revista Brasileira de Ensino de Física, v. 29, n. 2, p. 251-266, 2007.

RINALDI, E.; GUERRA, A. A história da ciência e o uso da instrumentação: construção de um transmissor de voz como estratégia de Ensino. Caderno Brasileiro de Ensino de Física, v. 28, n. 3: p. 653-675, 2011. 
ROEHRIG, S. A. G.; CAMARGO, S. A educação com enfoque CTS no quadro das tendências de pesquisa em Ensino de ciências: algumas reflexões sobre o contexto brasileiro atual. Revista Brasileira de Ensino de Ciência e Tecnologia, v. 6, n. 2, 2013.

SANTOS, M. E. V. M. A Cidadania na "Voz" dos manuais escolares. Porto: Livros Horizonte, 2001.

SANTOS, W. L. P.; MORTIMER, E. F. Uma análise de pressupostos teóricos da abordagem C-T-S (Ciência - Tecnologia - Sociedade) no contexto da educação brasileira. Ensaio Pesquisa em Educação em Ciências, v. 2, n.2, 2002.

SANTOS, W. L. P.; SCHNETZLER, R. P. Educação em química: compromisso com a cidadania. Ijuí: Unijuí, 1997.

SASSERON, L. H.; CARVALHO, A. M. P. Alfabetização científica: uma revisão bibliográfica. Investigações em Ensino de Ciências, v. 16, n.1, p. 59-77, 2011.

SENRA, C. P.; BRAGA, M. Pensando a natureza da ciência a partir de atividades experimentais investigativas numa escola de formação profissional. Caderno Brasileiro de Ensino de Física, v. 31, n. 1, p. 7-29, 2014.

SILVA, A. C.; ALMEIDA, M. J. P. M. A noção de mobilização na associação da Física a objetos tecnológicos contemporâneos. Ciência \& Educação, v. 21, n. 2, p. 417-434, 2015.

SILVA, M. G. L. Repensando a Tecnologia no Ensino de Química do Nível Médio: Um Olhar em Direção aos Saberes Docentes na Formação Inicial. Tese (Doutorado em Educação). Universidade Federal do Rio Grande do Norte. Natal, 2003.

SILVA, S. L. A.; VIANA, M. M.; MOHALlEM, N. D. S. Afinal, o que é Nanociência e Nanotecnologia? Uma Abordagem para o Ensino Médio. Química Nova na Escola, v.31, n.3, 2009.

SILVEIRA, R. M. C. F.; BAZZO, W. Ciência, tecnologia e suas relações sociais: a percepção de geradores de tecnologia e suas implicações na educação tecnológica. Ciência \& Educação, v.15, n.3. p. 681-694, 2009.

TAKAHASHI, J. A.; MARTINS, P. F. F.; QUADROS, A. L. Questões Tecnológicas Permeando o Ensino de Química: O Caso dos Transgênicos. Química Nova na Escola, n. 29, 2008.

TRIVIÑOS, A. N. Introdução à pesquisa em ciências sociais: a pesquisa qualitativa em educação, São Paulo: Atlas, 1987.

UTGES, G.; FERNÁNDEZ, P.; JARDÓN, A. Física y tecnología: una integración posible. Caderno Catarinense de Ensino de Física, v. 13, n. 2, p.108-120, 1996. 
UTGES, G.; JARDÓN, A.; FERABOLI, L.; FERNÁNDEZ, P. Visión de professores en ejercicio respecto de la enseñanza de la Tecnología: un estudio en Argentina. Ciência \& Educação, v.7, n.1. p. 29-45, 2001.

VASCONCELOS, S. D.; SOUTO, E.. O Livro Didático de Ciências no Ensino Fundamental: proposta de critérios para análise do conteúdo zoológico. Ciência \& Educação, v. 9, n. 1, p. 93 - 104, 2003.

VERASZTO, E. V.; SILVA, D.; CAMARGO, E. P. BARROS FILHO, J. Concepções de tecnologia de graduandos do estado de São Paulo e suas implicações educacionais: breve análise a partir de modelagem de equações estruturais. Ciência \& Educação, v. 19, n. 3, p. 761-779, 2013.

VERASZTO, E. V.; SILVA, D.; MIRANDA, N. A.; SIMON, F. O. Tecnologia: Buscando uma definição para o conceito. PRISMA.COM, n. 7, 2008. 